CENTRO UNIVERSITÁRIO FEI

NELSON TESTA FILHO

\title{
ANÁLISE DA RELAÇÃO ENTRE TECNOLOGIA DA INFORMAÇÃO, PRÁTICAS DA MANUFATURA ENXUTA E DESEMPENHO OPERACIONAL
}


NELSON TESTA FILHO

\section{ANÁLISE DA RELAÇÃO ENTRE TECNOLOGIA DA INFORMAÇÃO, PRÁTICAS DA MANUFATURA ENXUTA E DESEMPENHO OPERACIONAL}

Dissertação de Mestrado apresentada ao Centro Universitário FEI para obtenção do título de Mestre em Engenharia Mecânica. Orientada pela Profa. Dra. Claudia Aparecida de Mattos.

São Bernardo do Campo 
Testa Filho, Nelson.

Análise da elação entre tecnologia da informação, práticas da manufatura enxuta e desempenho operacional / Nelson Testa Filho. São Bernardo do Campo, 2016.

$90 \mathrm{p}$.

Dissertação - Centro Universitário FEI.

Orientadora: Prof. ${ }^{a}$ Dra. Cláudia Aparecida de Mattos.

1. manufatura enxuta. 2. tecnologia da informação. 3. desempenho operacional. I. de Mattos, Cláudia Aparecida, orient. II. Título.

Elaborada pelo sistema de geração automática de ficha catalográfica da FEI com os dados fornecidos pelo(a) autor(a). 
Aluno: Nelson Testa Filho

Título do Trabalho: Análise da relação entre tecnologia da informação, práticas da manufatura enxuta e desempenho operacional.

Área de Concentração: Produção

Orientador: Prof. a Dr. ${ }^{a}$ Claudia Aparecida de Mattos

Data da realização da defesa: 19/12/2016

ORIGINAL ASSINADA

\section{Avaliação da Banca Examinadora:}

São Bernardo do Campo, 19 / 12 / 2016.

\section{MEMBROS DA BANCA EXAMINADORA}

Prof. a Dr. a Claudia Aparecida de Mattos

Ass. :

Prof. Dr. Dário Henrique Alliprandini

Ass. :

Prof. Dr. Fernando José Barbin Laurindo

Ass.:

A Banca Julgadora acima-assinada atribuiu ao aluno o seguinte resultado:

APROVADO $\bigotimes \quad$ REPROVADO

\section{VERSÃO FINAL DA DISSERTAČ̃̃O}

APROVO A VERSÃO FINAL DA DISSERTAÇÃO EM QUE FORAM INCLUÍDAS AS RECOMENDAÇÕES DA BANCA EXAMINADORA
Aprovação do Coordenador do Programa de Pós-graduação

Prof. Dr. Rodrigo Magnabosco 
À Deus e a minha família, que sempre esteve ao meu lado em todos os momentos da minha vida. 


\section{AGRADECIMENTOS}

Primeiramente a Deus, pela minha vida.

A minha mãe Vera, por seu amor, apoio e dedicação. Sempre presente em minha vida.

A meu pai Nelson, por seu amor e exemplo de vida. Que saudades!

A minha filha Beatriz, um sonho realizado. Obrigado pelo seu amor.

A minha esposa Patrizia, meu tesouro. Amor serás minha eterna companheira.

A minha orientadora, Profa. Dra. Cláudia Aparecida de Mattos, pela sua preciosa orientação, uma mentora compreensiva e presente que conquistou meu respeito e admiração.

Aos professores da FEI, pelo conhecimento e experiência compartilhados.

Aos colegas, pelo convívio e experiências vividas.

Aos funcionários das empresas pesquisadas pela disponibilidade em participar desta pesquisa. 


\section{RESUMO}

O cenário dos negócios mudou de forma significativa nos últimos anos e, diante da competitividade global, a tecnologia da informação (TI) e a manufatura enxuta (Lean Manufacturing) são recursos que permitem contribuições para o desempenho da empresa. Os princípios e as práticas da manufatura enxuta são reconhecidos no mundo inteiro como a maneira mais eficaz de construir e sustentar a melhoria contínua das empresas. Melhorar a produtividade, reduzir custos e oferecer produtos de qualidade são fatores vitais para as empresas em qualquer parte do mundo. Com a evolução da informática através dos equipamentos e programas tornou-se possível a existência de uma tecnologia de informação (TI), sendo desenvolvidas muitas funcionalidades, ao longo do tempo, para auxiliar na organização dos processos produtivos das empresas e atender às necessidades de informação de vários departamentos de forma integrada. Embora seja reconhecida a importância destes recursos, a aplicação da TI bem como os princípios da manufatura enxuta têm sido vistos por alguns autores como mutuamente exclusivos, mas ambas as abordagens são cada vez mais interdependentes, pois as informações de produção em tempo real são fundamentais para o processo decisório nas organizações. Tomando, então, como base esta discussão sobre a TI e a manufatura enxuta, o objetivo deste estudo consiste em analisar como as empresas estão aplicando as práticas da manufatura enxuta aliadas aos recursos da tecnologia da informação, discutir o seu relacionamento nas organizações e comparar os resultados em termos de desempenho. Para o desenvolvimento da pesquisa, foi aplicada a abordagem qualitativa por meio do método estudo de caso.

Palavras-chave: Manufatura enxuta. Tecnologia da informação. Desempenho operacional. 


\begin{abstract}
The business scenario has changed significantly in recent years and, in the face of global competitiveness, information technology (IT) and lean manufacturing (Lean Manufacturing) are resources that enable contributions to the company's performance. The principles and practices of lean manufacturing are recognized worldwide as the most effective way to build and sustain continuous business improvement. Improving productivity, reducing costs and providing quality products are vital factors for businesses any part of the world. With the evolution of informatics through the equipments and programs it became possible the existence of an information technology (IT), being developed many functionalities over time to assist in the organization of the productive processes of the companies and to meet the information needs of several departments in an integrated way. Even though the importance of these features is recognized, the application of IT as well as the principles of lean manufacturing have been viewed by some authors as mutually exclusive, but both approaches are increasingly interdependent by the fact that production information in real time is fundamental for the decision-making process in organizations. By taking the discussion above based on IT and lean manufacturing, the objective of this study is to analyze how companies are applying lean manufacturing practices combined with information technology resources, discuss their relationships in organizations and compare results in terms of operational performance. For the development of the research, the qualitative approach was applied through the case study method.
\end{abstract}

Keywords: Lean manufacturing. Information Technology. Operational performance. 


\section{LISTA DE ILUSTRAÇÕES}

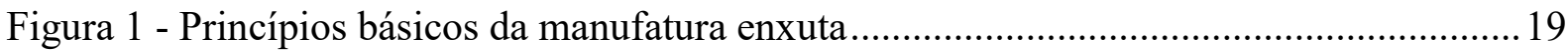

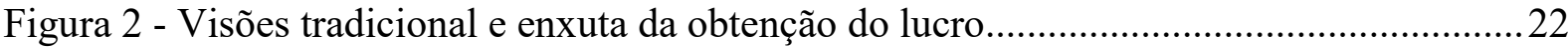

Figura 3 - Visões tradicional e enxuta da obtenção de melhorias .............................................2 23

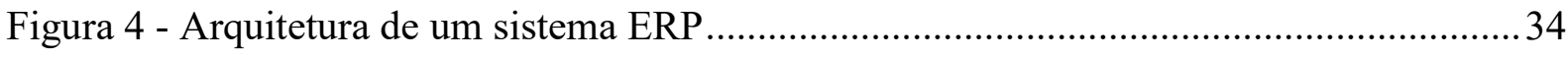

Figura 5 - Modelo de Henderson e Venkatraman ............................................................... 40

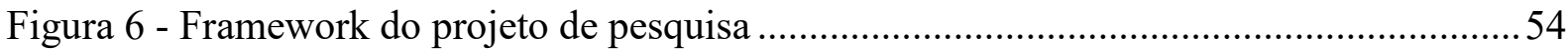

Figura 7 - Convergência e não convergência de múltiplas fontes de evidências ..................... 55 


\section{LISTA DE QUADROS}

Quadro 1 - Produção em massa x Manufatura enxuta............................................................ 18

Quadro 2 - Resumo do paradoxo entre a manufatura enxuta e ERP ....................................... 35

Quadro 3 - Comparação entre BI estratégico, tático e operacional ............................................39

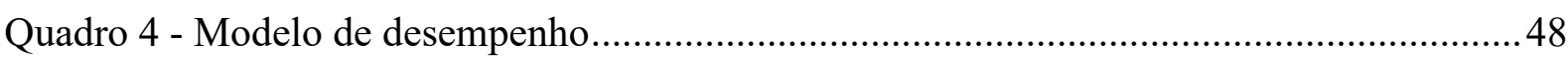

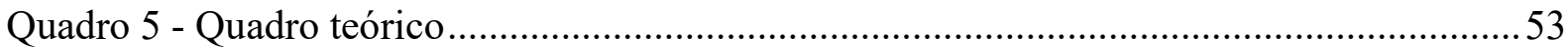

Quadro 6 - Pontos fortes e fracos de fontes de evidências ........................................................56

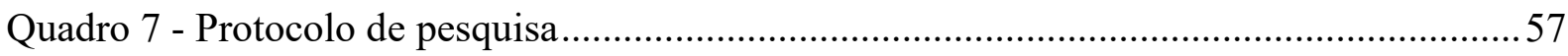

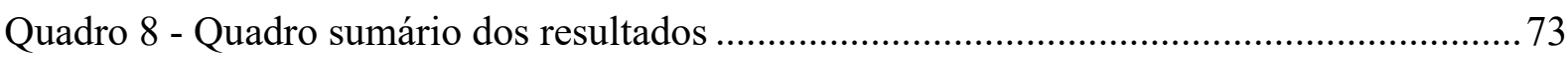




\section{LISTA DE TABELAS}

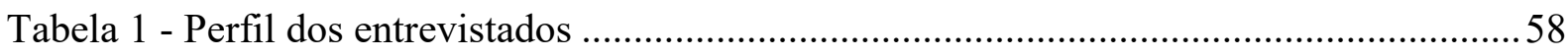

Tabela 2 - Análise conforme norma SAE J4000 para empresa A ..........................................61

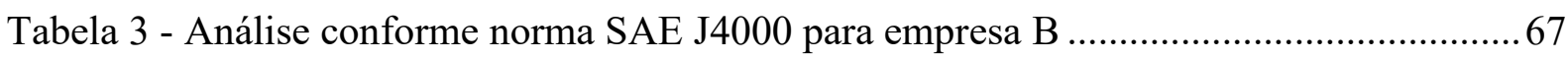




\section{LISTA DE ABREVIATURAS E SIGLAS}

$5 \mathrm{~S}$

5 sensos

AV Atividades que agregam valor

BI Business intelligence

CRM Customer relationship management

DO Desempenho operacional

DPM Dynamic performance monitor

ERP Enterprise resource planning

JIT Just in time

KM Kanban de movimentação

KP Kanban de produção

KPI Key performance indicator

LM Lean manufacturing

MES Manufacturing execution systems

MESA Manufacturing execution systems association

MRP Materials requirements planning

MRP II Manufacturing resources planning

NAV Atividades que não agregam valor

NAVN Atividades que não agregam valor, mas são necessárias

PLM Product lifecycle management

POP Procedimento operacional padrão

SAE Society for automotive engineers

SMED Single minute exchange of dies

SQDC Safety, quality, delivery, cost

TI Tecnologia da informação

TPM Total productive maintenance

TPS Toyota production system

TQM Total quality management

TRF Troca rápida de ferramenta

VSM Value stream mapping 


\section{SUMÁRIO}

1 INTRODUÇÃ

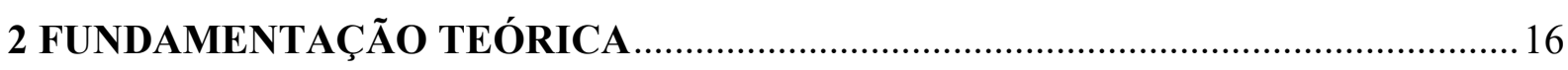

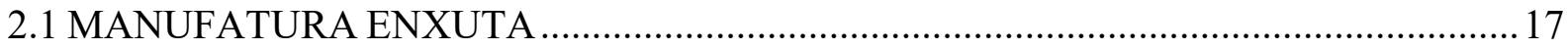

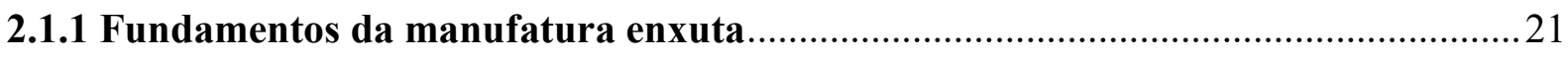

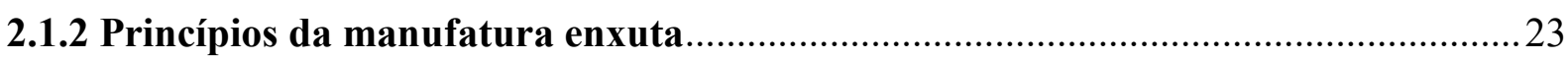

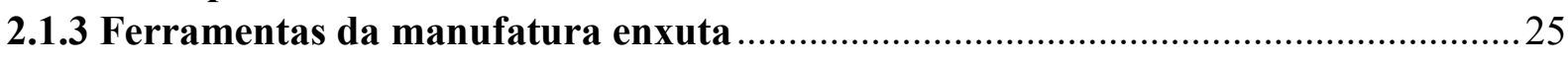

2.2 MANUFATURA ENXUTA E TECNOLOGIA DA INFORMAÇÃO ..................................32

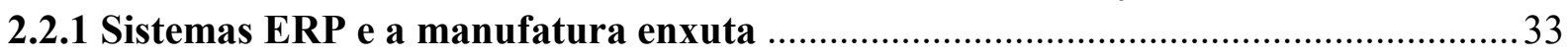

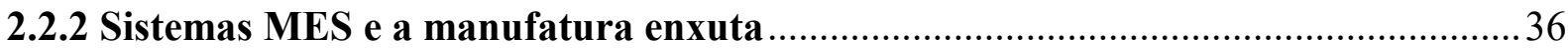

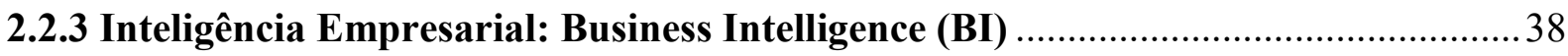

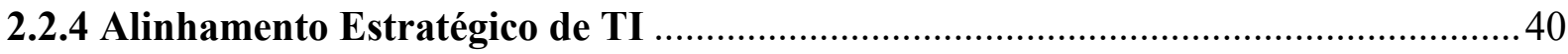

2.2.5 Sistemas Interorganização (empresa e fornecedor) ……………………………..... 42

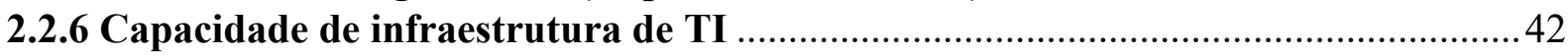

2.3 MANUFATURA ENXUTA E SUA MEDIÇÃO DE DESEMPENHO..................................4

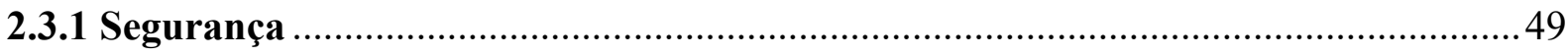

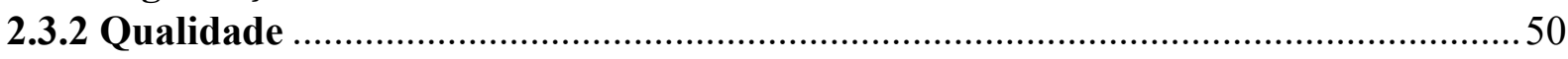

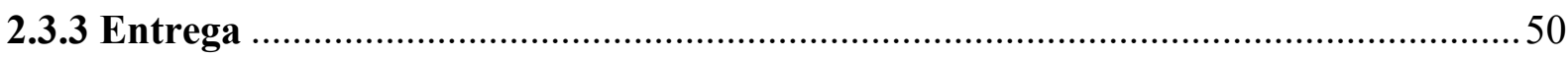

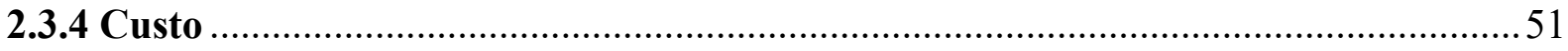

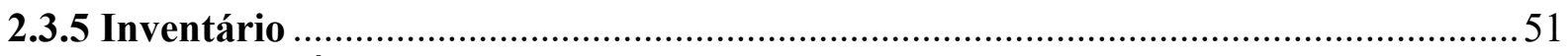

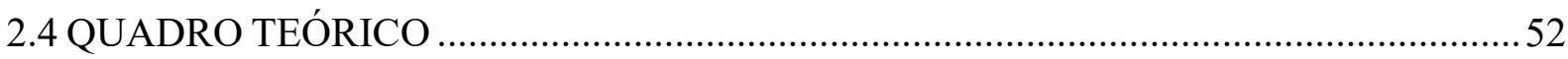

3 METODOLOGIA

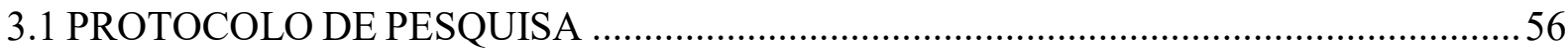

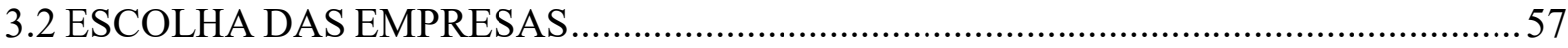

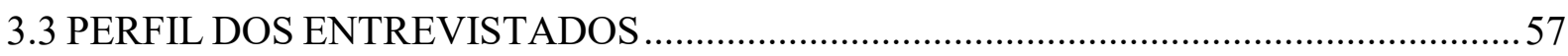

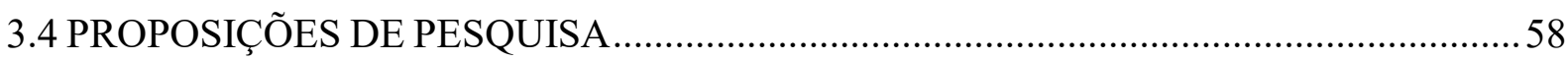

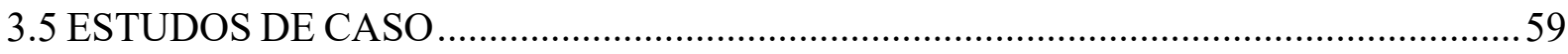

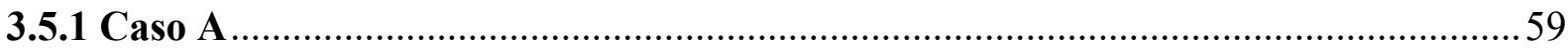

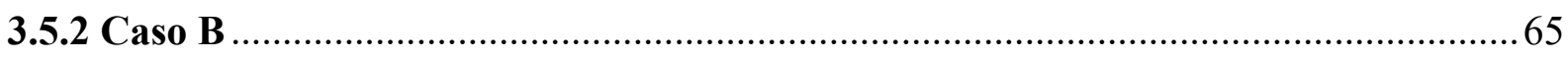

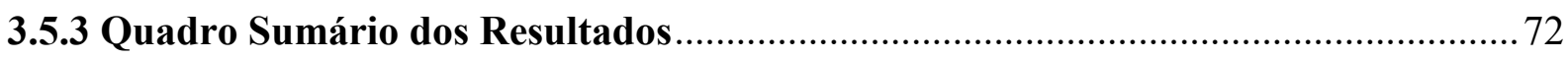

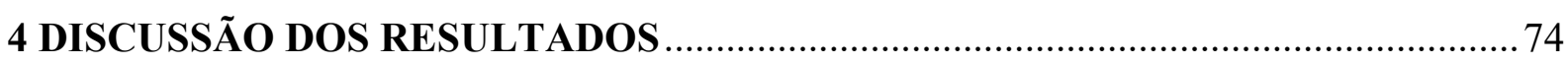

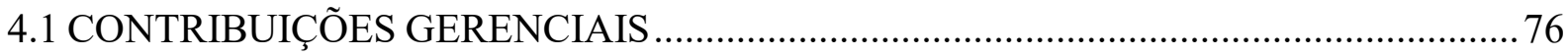

4.2 SUGESTÃO PARA TRABALHOS FUTUROS ………………………………….........

5 CONCLUSÃO.

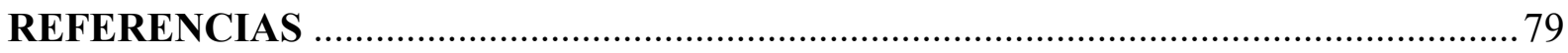

APÊNDICE A - BASE PARA AVALIAÇÃO DO NÍVEL DA IMPLANTAÇÃO DA

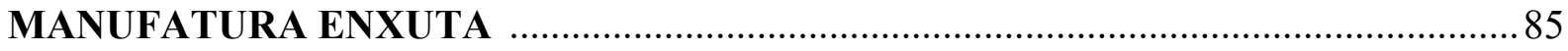




\section{INTRODUÇÃO}

No atual contexto, as empresas precisam aproveitar o máximo dos recursos disponíveis para obter o melhor rendimento nos negócios. Uma das iniciativas estratégicas que auxiliam os fabricantes a se manterem competitivos é a manufatura enxuta, uma filosofia que tem como base a produtividade. Por isso, trata-se de um processo contínuo em busca da perfeição. Para identificar oportunidades de melhorias e avaliar o progresso, a informação deve estar disponível através da utilização de ferramentas de software que permitem aos fabricantes adotar, atualizar ou expandir suas soluções de TI empresarial. Nesse aspecto, destacam-se algumas delas: Enterprise Resource Planning (ERP), Gestão do ciclo de vida do produto $(\mathrm{PLM})$ e Business Intelligence $(\mathrm{BI})$, para os quais a informação de produção em tempo real é crucial para as operações de produção diárias. Assim, os diferentes tipos de ferramentas de software podem analisar os dados em tempo real e transformá-los em conhecimento valioso para otimizar as operações de fabricação. A dificuldade de integrar vários sistemas, contudo, fez com que os fornecedores de software criassem vários componentes de gerenciamento de execução de forma individual. A aplicação sistemática de práticas enxutas e o sistema de Tecnologia da Informação, particularmente o sistema ERP, podem melhorar a eficiência da organização, mesmo em pequenas e médias empresas (POWELL; RIEZEBOS; STRANDHAGEN, 2012).

Cottyn et al. (2011) destacam que a aplicação da TI e os princípios da manufatura enxuta têm sido vistos como mutuamente exclusivas, mas ambas as abordagens são cada vez mais interdependentes, pois as informações de produção em tempo real são fundamentais para o processo decisório nas organizações. Riezebos, Klingenberg e Hicks (2009) destacam em seu estudo a questão da relação entre a TI e a manufatura enxuta, efetuando uma análise sobre as perspectivas de alinhamento da utilização dos sistemas de informação.

Segundo Cottyn et al. (2011), a principal razão para a TI não seja explorada pelos praticantes da manufatura enxuta é a sua tendência a se tornar obsoleta. Ward e Zhou (2006) indicam em seus estudos a importância da integração da TI com as práticas da manufatura enxuta, mas sugerem pesquisas para confirmar o efeito positivo para o seu desempenho.

Moyano-Fuentes e Sacristán-Díaz (2012) discutem as inter-relações existentes entre a tecnologia da informação (TI) e o emprego da manufatura enxuta. Mais especificamente, o nível de adoção das práticas da manufatura enxuta é estudado de acordo com o grau de utilização e o tipo de ferramentas adotadas. Os resultados desse estudo indicam que as empresas precisam aumentar o grau de utilização de TI interno ou intra-organizacional, a fim 
de aumentar o nível de implementação da manufatura enxuta e, portanto, melhorar sua eficiência. Os autores destacam a importância de investigar a relação entre a implementação de TI (interna e externa), práticas da manufatura enxuta e os objetivos estratégicos estabelecidos pela empresa, tais como a eficiência interna versus o crescimento do mercado. Adicionalmente, os autores citados mencionam que a TI e as práticas da manufatura enxuta apresentam uma dualidade, pois, ao mesmo tempo em que a TI e a manufatura enxuta se complementam, elas podem competir entre si no nível de gestão: de um lado, porque é necessário ter diferentes competências por parte da organização para trabalhar no ambiente da manufatura enxuta, de outro, porque os recursos financeiros e a atenção da alta gerência requerida por cada iniciativa frequentemente fazem com que as empresas não trabalhem simultaneamente estas inciativas, conforme destacam Ward e Zhou (2006). Khanchanapong et al (2014) complementam a problemática sobre tecnologia e a manufatura enxuta discutindo efeitos complementares das tecnologias de produção e práticas enxutas sobre o desempenho operacional de fabricação e indicam a necessidade de estudos adicionais tratando desta temática.

A partir do contexto discutido pelos autores mencionados - Riezebos, Klingenberg e Hicks (2009), Cottyn et al. (2011), Moyano-Fuentes e Sacristán-Díaz (2012), Khanchanapong et al (2014) -, observa-se uma lacuna na teoria que consiste em compreender o relacionamento da tecnologia de informação e as práticas da manufatura enxuta com o propósito de melhorar o desempenho operacional das empresas. Sendo assim, formulou-se a pergunta de pesquisa a seguir, que norteou o desenvolvimento da pesquisa: Como a tecnologia da informação contribui para as práticas da manufatura enxuta e o impacto no desempenho operacional da empresa?

Tomando como base esta discussão sobre TI, manufatura enxuta e desempenho operacional, o objetivo geral deste estudo consiste em analisar o alinhamento da TI às práticas e aos objetivos da manufatura enxuta, a fim de compreender se este relacionamento existe e sua respectiva contribuição para a melhoria do desempenho operacional. Os trabalhos quantitativos realizados em empresas de grande porte indicam efeito positivo, mas se torna necessário um melhor entendimento.

Este estudo está dividido nos seguintes tópicos: a) apresentação dos conceitos pertinentes à manufatura enxuta; b) na seção 2.2 são discutidos os trabalhos relacionados com Tecnologia da Informação e sua interação com manufatura enxuta; c) na seção 2.3 debate-se o desempenho e os respectivos indicadores para este ambiente; d) o tópico 3 refere-se ao 
aspecto metodológico da pesquisa e ao procedimento adotado para o desenvolvimento do estudo de campo. 


\section{FUNDAMENTAÇÃO TEÓRICA}

As técnicas utilizadas na manufatura enxuta têm como base o Sistema Toyota de Produção (TPS), cujo objetivo principal é a redução do desperdício aprimorando as técnicas de utilização dos equipamentos e o aproveitamento contínuo do tempo durante o processo, incluindo o esforço humano (WOMACK; JONES; ROOS, 1992), que pretendia melhorar a produtividade, aumentar a qualidade e alcançar ranking mundial no mercado automotivo global. Esse conceito superou o de fábricas norte-americanas, provocando uma corrida desses americanos para resolver as principais diferenças entre a TPS da Toyota, a indústria automobilística europeia e os sistemas tradicionais da América do Norte. Surge, então, o "pensamento enxuto" com vistas a abranger a melhoria da produtividade dentro das organizações de serviços.

A implantação da manufatura enxuta é complexa, demorada e requer a alocação de uma quantidade substancial de recursos por parte de empresas (LIAN; VAN LANDEGHEM, 2007). Muitas, de pequeno e médio porte, porém, não conseguiram acompanhar a velocidade da transformação tecnológica em que se vive atualmente, devido a vários fatores que vão desde uma política governamental que dê apoio às pequenas empresas até à falta de mão-deobra qualificada para a aplicação de novas técnicas relacionadas à manufatura enxuta. Peças e Henriques (2006) destacam a importância e a necessidade das universidades de contribuírem com as pequenas e as médias empresas na execução das melhores práticas da manufatura enxuta e colocam alguns pontos importantes para o desenvolvimento do trabalho enxuto em parceria com as universidades: a colaboração entre as universidades e as pequenas e médias empresas deve se basear em uma pequena base de projetos centralizados nas áreas de maior necessidade:

a) Projetos devem ter o seu foco nas áreas problemáticas das empresas, cujo potencial de melhoria e de inovação seja o maior possível;

b) Projetos de melhorias devem diagnosticar a situação problemática e propor novas soluções com base nas metodologias da manufatura enxuta.

Até recentemente, a ideia de usar software de apoio a um projeto de manufatura enxuta não era aceita porque o sistema TPS tem como base duas filosofias centradas na cultura japonesa: eliminação do desperdício e o respeito pelas pessoas (JACOB; CHASE; 
AQUILANO, 2009). Contudo, tem-se observado uma evolução neste cenário, como será mostrado adiante.

\subsection{MANUFATURA ENXUTA}

A estratégia de manufatura é uma das principais preocupações das empresas devido à sua grande importância no atual mercado competitivo, motivo pelo qual buscam cada vez mais mecanismos de diferenciação em relação a seus concorrentes. Womack e Jones (1996) afirmam que o pensamento é enxuto porque descreve uma maneira de produzir cada vez mais com menos, ou seja, menos esforço humano, menos equipamentos, menos espaço e menos tempo; em contrapartida, está cada vez mais próximo de oferecer aos clientes precisamente o que anseiam.

Shah e Ward (2003) sugerem e apontam a possibilidade de se aplicarem 22 práticas de manufatura enxuta nas empresas; porém, consideram as metodologias Just-in-Time (JIT), Total Quality Management (TQM) e a Total Productive Maintenance (TPM) como sendo de alta performance para o processo produtivo e que o tamanho e a idade da empresa têm substancial influência na prática das metodologias, ou seja, naturalmente, quanto maior a empresa maior é a sua utilização.

Achanga et al. (2006) destacam quatro fatores críticos que devem ser considerados para uma aplicação bem-sucedida da manufatura enxuta dentro das pequenas e médias empresas: são as práticas de Liderança, Conhecimento da Gerência, Cultura Organizacional e as Habilidades e Perícias do grupo de trabalho. A ausência de investimentos nesses pontos inibe a oportunidade de empregar uma equipe ideal, impedindo que as pequenas e médias empresas pratiquem as melhores estratégias de produtividade utilizando a manufatura enxuta.

Segundo Ohno (1997), a manufatura enxuta é a busca de tecnologias de produção que racionalizam a quantidade de equipamentos e mão-de-obra, produzindo bens com qualidade e eliminando todas as variáveis que não contribuam com a qualidade, o preço ou o prazo de entrega. Para Womack, Jones e Roos (1992), a manufatura enxuta enfoca um maior número de funções e responsabilidades possíveis a todos os trabalhadores que adicionam valor ao produto na linha e adota um sistema de tratamento de defeitos sempre que os problemas são identificados, analisando e aplicando técnicas possíveis para solucioná-los na sua causa raiz. 
Quadro 1 - Produção em massa x Manufatura enxuta

\begin{tabular}{|c|c|c|}
\hline Tópicos & Produção em Massa & Manufatura Enxuta \\
\hline Lead Time & Longos prazos de entrega & Curtos prazos de entrega \\
\hline Tamanho dos lotes & Grandes lotes & Pequenos lotes \\
\hline Layout & Funcional & Produto e Fluxo \\
\hline Estoque & Uma alternativa & Ulto giro $>10$ \\
Baixo giro $<7$
\end{tabular}

Fonte: Autor “adaptado de” Black, 1998.

Segundo Sanches e Perez (2001), o interesse na manufatura enxuta por parte das empresas está baseado principalmente na evidência empírica de que ela aumenta a sua competitividade. O principal objetivo ao se introduzir um programa de manufatura enxuta está no aumento da produtividade, redução do tempo de processamento, redução dos custos e melhoria da qualidade. Entretanto, nem sempre é fácil justificar a implementação do programa de manufatura enxuta devido à queda de produtividade nos primeiros estágios, sendo fortemente desencorajada pelo sistema de gerenciamento contábil tradicional. Para verificar as mudanças durante a implementação é necessária a adoção de alguns indicadores intermediários, entretanto existem poucos estudos empíricos que analisaram o uso de indicadores intermediários para observar as mudanças na manufatura voltadas à manufatura enxuta. Alguns princípios da manufatura enxuta afetam exclusivamente a produção, enquanto outros integram as várias funções da empresa.

A Figura 1 mostra os princípios básicos da manufatura enxuta. 
Figura 1 - Princípios básicos da manufatura enxuta Fonte: Sanches e Perez, 2001.

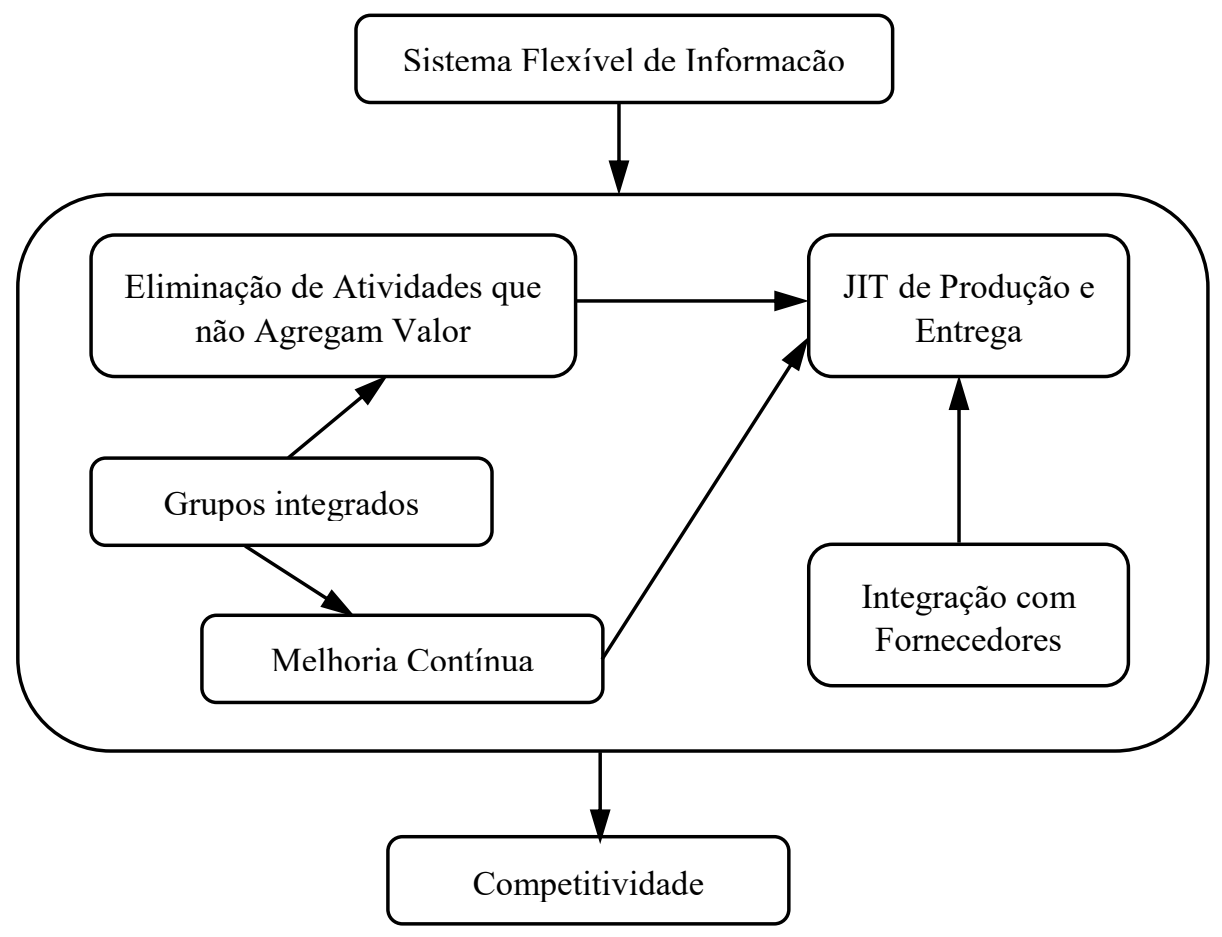

Para Black (1998), um sistema de manufatura integrado produz qualidade superior a um custo menor e com menor tempo de atravessamento, mantendo-se o mínimo de tempo com estoques em processo, proporcionando a correta estrutura para uma futura automação, dando bases para possíveis correções de problemas de qualidade ou de capacidade produtiva. $\mathrm{Na}$ evolução do processo de produção em massa para a manufatura enxuta é preciso seguir dez passos, no intuito de atingir a eficiência do processo produtivo. São eles:

a) Passo 01 - Formar células de manufatura e de montagem - Construir a Fundação

Segundo Black (1998), criar células de produção deve ser o primeiro passo para se projetar um sistema produtivo em que controles de produção, inventários e qualidade são partes integrantes. As células são grupos de processos projetados para fabricar certa família de produtos de uma forma flexível. A movimentação de peças dentro das células ocorre em lotes unitários e os trabalhadores das células devem ser multifuncionais.

b) Passo 02 - Reduzir ou eliminar trocas de ferramentas

A Troca Rápida de Ferramentas (TRF) utiliza-se de dispositivos para reduzir ou eliminar a preparação (setup), ou seja, o tempo de troca de ferramenta dentro da célula deve 
ser o menor possível. Dentro das células cada indivíduo deve ser treinado para reduzir o tempo de setup, utilizando os princípios Single Minute Exchange of Die (SMED).

c) Passo 03 - Integrar o controle de qualidade

As células de produção desenvolvem um ambiente propício ao controle de qualidade, uma vez que internamente as peças defeituosas são segregadas do processo produtivo.

d) Passo 04 - Integrar a manutenção preventiva

A confiabilidade do equipamento deve ser atingida aplicando-se um programa de manutenção preventiva com treinamento dos operadores e utilização de ferramentas adequadas. O operador é responsável pela limpeza do equipamento e do posto de trabalho.

e) Passo 05 - Nivelar e balancear

O sistema produtivo deve ser nivelado, ou seja, cada processo deve produzir a mesma quantidade em pequenos lotes para minimizar o choque da mudança. O sistema é considerado sincronizado quando se produz a mesma quantidade de determinado produto, diariamente, de acordo com a necessidade. Observa-se ainda que os longos tempos de preparação e de montagem devem ser eliminados.

f) Passo 06 - Integrar as células

Ligar as células entre si utilizando-se do Kanban e integrando o controle de produção. Os processos subsequentes ditam o ritmo de produção dos precedentes.

Somente a montagem final é programada. A estrutura do layout do sistema produtivo é que determina os caminhos que as peças devem percorrer na fábrica. Este passo inicia-se pela conexão com Kanbans, por meio de duas abordagens:

- Kanban de movimentação (KM), o que puxa o material em direção aos processos subsequentes, ou seja, de uma célula para outra;

- Kanban de produção (KP), o que atua como controlador das células, programando o que fazer, em qual pedido incluir o que foi fabricado e quanto fabricar. Os roteiros são eliminados e as informações acerca da movimentação dos materiais fluem em sentido contrário ao material.

g) Passo 07 - Reduzir estoque em processo 
A integração do controle de estoque no sistema reduz o tamanho dos lotes e os estoques de processos, ou seja, o Kanban serve como um pulmão, protegendo os elementos de processos subsequentes de problemas nos processos precedentes. A redução controlada do nível de estoque permite detectar os possíveis problemas, ao invés de usar altos estoques para protegê-los.

h) Passo 08 - Montar programas de fornecimento

Este passo consiste em educar e encorajar os fornecedores a desenvolverem sistemas produtivos de qualidade superior, com baixo custo e menores prazos de entrega. Os fornecedores devem ter condições de entregar materiais onde e quando necessário, garantindo a qualidade, evitando-se a inspeção de recebimento.

i) Passo 09 - Automatizar

É a transformação das células manuais em células independentes, o que garante qualidade e capacidade produtiva, eliminando gargalos.

j) Passo 10 - Informatizar

A informatização total do sistema integrado de manufatura é o último passo para a conversão do sistema. Neste ponto, o sistema é simples e flexível o suficiente para um controle eficiente via computador.

De uma forma geral, todo sistema de manufatura tem funções de controle que devem ser realizadas independentemente do tipo de sistema de manufatura, sendo algumas dessas ferramentas manuais, tais como: cartões kanban, luzes andon, sistemas poka-yoke, ordens verbais e sistemas informatizados (tecnologia da informação).

\subsubsection{Fundamentos da manufatura enxuta}

O trabalho da Toyota, cujo foco é eliminar ou minimizar todas as atividades que são detectadas e classificadas como não agregadoras de valor, tem como plano de fundo uma mudança no paradigma da forma como as empresas entendem e buscam lucro. Rasteiro (2009) explica que a forma tradicional de pensamento é decidir o preço através da somatória dos valores de custo e a margem de lucro desejada enquanto que a produção enxuta defende que o preço seja mantido constante e a margem de lucro aumentada através da diminuição dos custos associados aos processos. A Figura 2 ilustra essa relação: 
Figura 2 - Visões tradicional e enxuta da obtenção do lucro Fonte: Stefanelli, 2007.

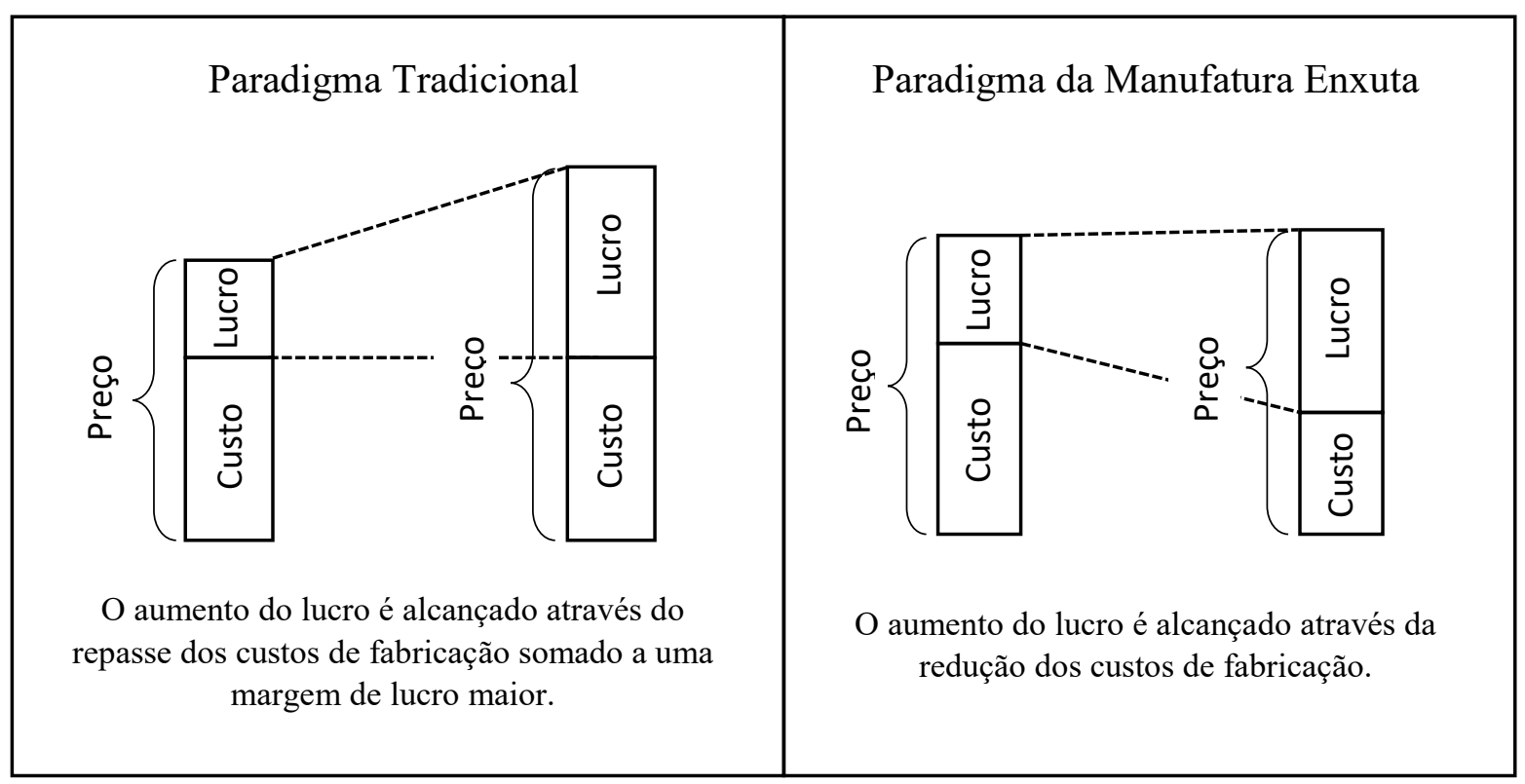

Observando a obtenção de lucros proposta pela manufatura enxuta, nota-se a importância da organização de métodos para diminuir o custo e eliminar perdas que ocorrem durante o processo de produção. Womack e Jones (1996) definem desperdício como toda atividade que consome recursos e não agrega valor para o cliente. Estas atividades são classificadas da seguinte maneira:

a) Atividades que agregam valor (AV): são aquelas que, para o cliente final, tornam o produto mais valioso;

b) Atividades que não agregam valor (NAV): são aquelas que, para o cliente final, não adicionam valor ao produto e não são necessárias sob quaisquer circunstâncias;

c) Atividades que não agregam valor, mas que são necessárias (NAVN): são aquelas que, para o cliente final, não adicional valor ao produto, mas são indispensáveis para que seja possível produzir.

Tradicionalmente, busca-se reduzir o lead time diminuindo o tempo das atividades que agregam valor, enquanto que a manufatura enxuta busca melhor eficácia nos processos que não agregam valor, reduzindo-os ao máximo ou eliminando-os. 
Figura 3 - Visões tradicional e enxuta da obtenção de melhorias

Fonte: Womack e Jones (1996).

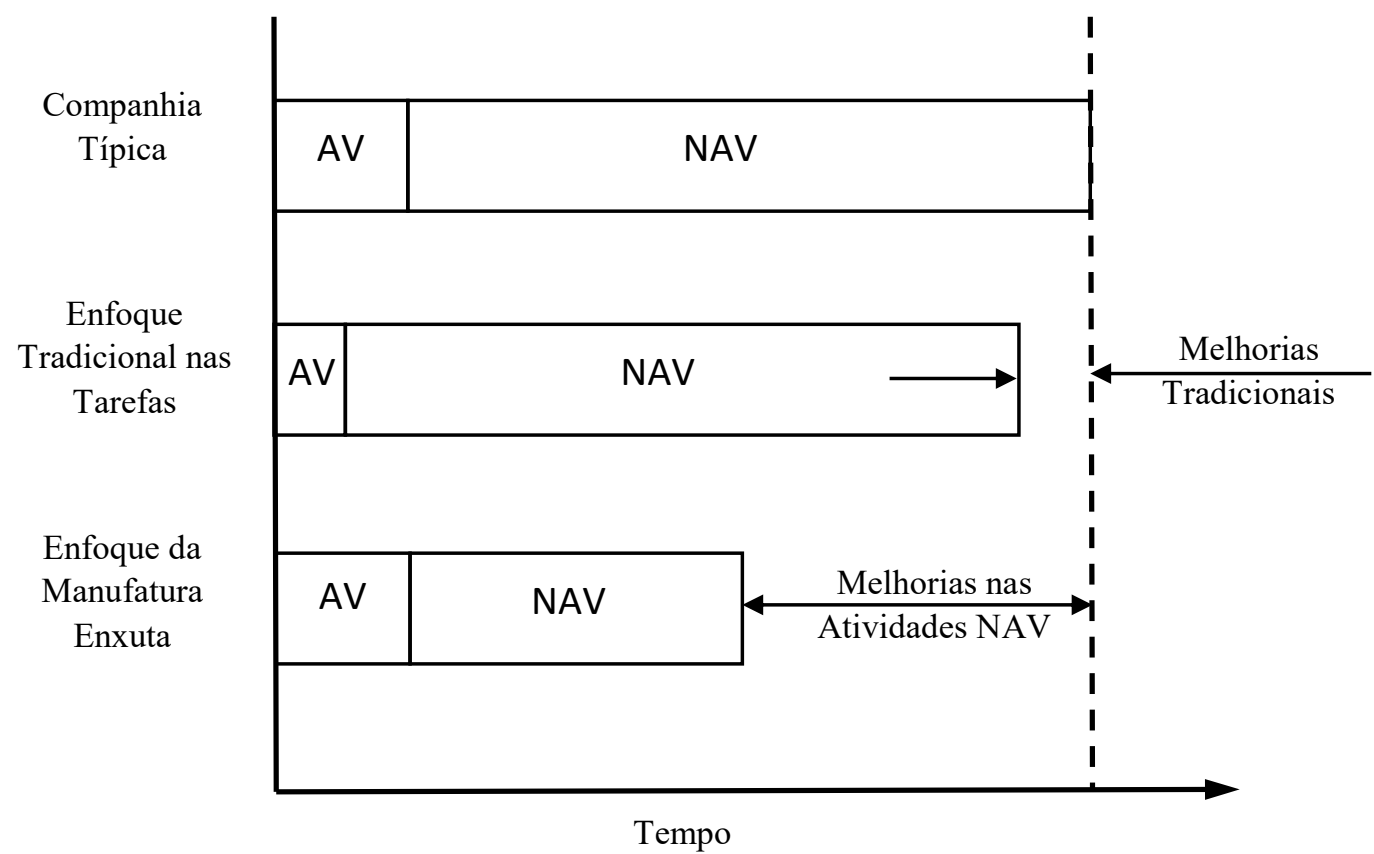

A base fundamental da manufatura enxuta é a eliminação absoluta do desperdício. Assim, Womack e Jones (1996) definem desperdício como sendo qualquer atividade humana que consome recursos e não agrega valor segundo a visão do cliente. Nesse sentido, Ohno (1997) classifica da seguinte maneira os desperdícios: superprodução, inventário em excesso, defeitos, processamento inapropriado, transporte excessivo, movimentação excessiva e esperas.

\subsubsection{Princípios da manufatura enxuta}

Womack e Jones (1996) condensam as práticas executadas pelas empresas que eram consideradas enxutas em cinco princípios, que são apresentados a seguir:

a) Determinar Valor

Inicialmente, a mentalidade enxuta tenta definir valor sob o ponto de vista do cliente, e não da empresa. Assim, é papel da empresa ou organização determinar primeiramente quais as necessidades dos clientes, atendê-las e então cobrar um preço justo que cubra as despesas e gere lucro para a empresa. 


\section{b) Fluxo de Valor}

Após a determinação do Valor, deve-se identificar o Fluxo do Valor, o que significa entender e esmiuçar toda a cadeia produtiva, separando-a em três tipos: atividades que agregam valor; atividades que não agregam valor, mas que são fundamentais nos processos com a qualidade necessária; e atividades que não agregam valor. Dessa forma, procura-se eliminar as atividades que não agregam valor, contribuindo para a diminuição dos custos e, consequentemente, para a melhoria da eficiência da empresa.

\section{c) Fluxo contínuo}

Em seguida, é necessário aplicar o conceito de Fluxo contínuo no processo, que visa garantir maior fluidez ao sistema produtivo. Para que isso ocorra de forma eficaz, é necessário modificar os valores envolvidos no processo, por partirem de uma estrutura essencialmente departamental. O Fluxo contínuo defende, na medida do possível, a ininterrupção do processo de fabricação, o que reflete positivamente na redução dos tempos de fabricação de produtos e nos estoques entre os processos, e, dessa forma, torna possível reduzir ao máximo os estoques intermediários.

\section{d) Produção Puxada}

Deve-se aplicar nos pontos do fluxo produtivo em que não é possível utilizar o fluxo contínuo, consistindo na inversão do paradigma de produção convencional. O conceito aplicado baseia-se em processos consumidores que gerenciam a demanda dos processos fornecedores, "puxando", assim, a produção. Dessa maneira, é produzido apenas o necessário e quando necessário, reduzindo a formação de estoques de itens intermediários e do produto final. Deve-se ressaltar, ainda, a importância da formação de supermercados, que são estoques mínimos de segurança entre os processos, para garantir que não ocorra falta de material durante o processo de fabricação controlado através de Kanban.

\section{e) Perfeição}

O último princípio da manufatura enxuta é a busca constante pela perfeição em todos os processos. É imprescindível que todos os envolvidos busquem continuamente alcançar a perfeição, melhorando as práticas e os processos, otimizando os resultados e buscando sempre agregar valor ao produto final. 


\subsubsection{Ferramentas da manufatura enxuta}

Este tópico busca identificar quais ferramentas características da filosofia de manufatura enxuta são utilizadas na prática do dia a dia do setor para auxiliar na aplicação da filosofia nos processos.

\subsubsection{Kanban - Sistemas Puxados}

O sistema puxado é uma inversão do conceito tradicional de produção empurrada, sendo que o objetivo principal é controlar o ritmo de produção fazendo com que apenas se produza quando o cliente assim precisar. Chaves Filho (2007) acrescenta ainda que o objetivo de um sistema puxado é o controle da produção, de forma que não haja necessidade da programação clássica, e que por meio desse sistema é possível realizar a previsão através das demandas reais dos clientes, diminuindo assim os riscos associados às técnicas de previsão de vendas que são comumente encontradas em sistemas empurrados.

Para controlar esse tipo de sistema, pode-se utilizar o controle kanban. Antonelli (2008) define este sistema como sendo um sistema visual de transmissão de informações e que uma de suas vantagens é evitar ou diminuir os problemas com gargalos que são gerados pelas fases mais lentas dos processos de produção, uma vez que estes processos lentos só serão abastecidos quando for necessário.

O controle Kanban, segundo Slack, Chambers e Johnston (2002), é um método de operacionalizar o sistema de planejamento e do controle puxado por meio de cartões contendo informações dos materiais para a realização das operações de movimentação e abastecimento, estabelecendo, assim, a forma mais simples de um estágio cliente avisar seu estágio fornecedor sobre a necessidade de material a ser enviado. Vale ressaltar que o próprio termo Kanban, na tradução para o português, significa cartão ou sinal.

\subsubsection{Kaizen (melhoria contínua)}

Saia (2009) explica que, após segunda guerra mundial, o Japão desenvolveu uma filosofia segundo a qual nenhum dia deveria passar sem que houvesse alguma melhoria, tanto na vida das pessoas quanto na vida das organizações. Nesse cenário, surgiu um conjunto de técnicas que visa à melhoria contínua, denominado Kaizen, que permitiu às empresas uma 
participação mais efetiva no mercado. Dessa forma, o Kaizen pode ser definido como uma melhoria contínua com a participação de todos os agentes produtivos. De acordo com Antonelli (2008), o Kaizen é uma meta vital do fluxo de valor, sendo necessário que a busca pelo aperfeiçoamento parta do pessoal e se reflita nas coisas externas, como processos, produtos, entre outros.

Segundo Stefanelli (2007), há duas classificações para os tipos de melhoria que podem ser feitos dentro de uma empresa: as de pequeno e as de grande porte. Além disso, explica que as de grande porte geralmente estão associadas à necessidade de grandes investimentos e longo tempo de implementação; as de pequeno porte, por sua vez, podem ser executadas com menos recursos, baixos investimentos, porém alcançam resultados mais modestos em curto prazo.

Ainda assim, o efeito cumulativo de várias melhorias de pequeno porte pode ser ainda mais significativo do que uma única de grande porte. Assim, tem-se o evento Kaizen como modelo para implementações cirúrgicas de melhorias. Esse processo é aplicado, segundo Bezerra (2008), por times preferencialmente multifuncionais, durante cinco dias e com uma apresentação para a alta gerência no final da semana. Durante esse período, a equipe fica alocada em tempo integral para se dedicar ao projeto, sendo necessário o apoio da alta gerência, que deve funcionar como facilitador de mudanças para que resulte no sucesso do projeto.

\subsubsection{Ferramenta $5 S$}

Trata-se de um método cujo objetivo principal é organizar e padronizar todo o local em que é executado um trabalho. O programa 5S é uma filosofia de trabalho que promove um ambiente mais agradável e produtivo através da conscientização e responsabilidade coletiva em torno da organização, limpeza e disciplina.

A base para o método são 5 sensos: Seiri, Seiton, Seiso, Seiketsu e Shitsuke. Saia (2009) comenta que, através da adoção do 5S, é possível alcançar melhores níveis de motivação e dedicação de trabalhadores devido a melhorias no ambiente de trabalho, redução no índice de acidentes, consequência direta da organização e limpeza dos locais de atividades e aumento da produtividade.

Dessa forma, Silva (2007) define os 5 sensos como:

a) Seiri (Senso da Utilização): Deve-se manter nos arredores do ambiente de trabalho 
apenas o que é necessário e que será utilizado nas atividades corriqueiras do local. Esse senso busca eliminar ou reduzir ao máximo a necessidade de movimentação por parte do operador, evitando que o mesmo tenha que se deslocar atrás de ferramentas ou recursos para a execução do trabalho e garantir que as ferramentas corretas serão utilizadas para os trabalhos corretos, eliminando, assim, improvisações.

b) Seiton (Senso de Ordenação): Significa que é necessário manter cada coisa em seu devido lugar. Algumas formas de auxiliar a implementação desse Senso são: marcações e identificações dos itens de trabalho e armários e gavetas devidamente ordenadas. Esse Senso se relaciona com o anterior quando se percebe que é preciso organizar tudo o que foi considerado necessário para o local de trabalho.

c) Seiso (Senso de Limpeza): Esse Senso tem como objetivo a manutenção da limpeza e higiene do local de trabalho, atacando as causas raiz da sujeira, criando uma cultura de limpezas rotineiras e visando manter um ambiente agradável para o bom desenvolvimento das atividades.

d) Seiketsu (Senso de Padronização): É necessário padronizar todos os tipos de códigos utilizados para a comunicação de forma a facilitar a visualização e o entendimento e garantir que a comunicação entre as pessoas seja eficiente.

e) Shitsuke (Senso da Autodisciplina): Responsável por buscar o aprimoramento contínuo das práticas descritas nos quatro primeiros Sensos. Visa garantir a sustentabilidade do método $5 \mathrm{~S}$, tentando fazer com que as práticas se tornem hábitos e sejam incorporadas ao dia a dia das pessoas.

Para Chaves Filho (2007), embora estes conceitos possam parecer simples, eles são muito úteis para facilitar a aplicação de outras ferramentas Enxutas, aumentando a produtividade e reduzindo o desgaste físico e mental, uma vez que não é necessário procurar ferramentas e tudo o que é preciso está sempre ao alcance e organizado.

\subsubsection{Manutenção Produtiva Total (Total Productive Maintenance - TPM)}

O objetivo do TPM é engajar um senso de união e responsabilidade entre os supervisores, operadores e técnicos da manutenção. A ideia é não se limitar a simplesmente manter o equipamento funcionando, mas também estender e otimizar o seu desempenho global (HUTCHINS, 1998). 
No TPM, o operador é o responsável pelas funções básicas de manutenção, liberando a equipe de manutenção para se concentrar em um trabalho mais preventivo. Os operadores se tornam uma peça-chave na conservação da máquina e têm a responsabilidade de reduzir as paradas no processo produtivo. Dessa forma, a eficiência do equipamento é maximizada, melhorando a capacidade dos operadores; em contrapartida, os custos de produção são reduzidos graças a um controle contínuo das máquinas pelos usuários.

A meta do TPM é aumentar a eficiência da planta e dos equipamentos. Para tanto, o TPM utiliza-se da manutenção autônoma, na qual os operários desenvolvem rotinas de inspeção, lubrificação e limpeza. Os padrões de limpeza e de lubrificação aplicados por um operário capacitado permitem encontrar e resolver anomalias durante o processo de fabricação.

\subsubsection{Mapeamento do Fluxo de Valor}

Para o mapeamento do fluxo de valor em si é necessário que se conheça tanto o fluxo de material quanto o fluxo de informações. Queiroz, Rentes e Araujo (2009) explicam que o fluxo de material deve ser desenhado na parte de baixo do mapa, da esquerda para direita, enquanto que o fluxo de informações é desenhado na parte superior do mapa, da direita para esquerda. Ainda, comentam que no fluxo de material é possível observar pontos em que o estoque se acumula, enquanto no fluxo de informações identificam-se os movimentos de materiais que são empurrados pelo produtor e não puxados pelo cliente.

Saia (2009) comenta a importância da formação das famílias de produtos antes de se iniciar o mapeamento em si. Uma família é formada por um grupo de produtos que compartilham os mesmos processos, passando pelas mesmas etapas de produção.

Para desenhar o mapa de estado futuro, é necessário que se levante também algumas informações importantes, definidas por Rother e Shook (2003) como métricas da manufatura enxuta:

a) Tempo de ciclo: é o tempo que uma peça ou componente leva para ser completamente processado, ou o intervalo de tempo entre a saída de dois produtos consecutivos de um processo.

b) Tempo de agregação de valor: tempo em que ocorre de fato a transformação do produto ou componente.

c) Lead time: Tempo que um produto leva para percorrer todo o fluxo de valor, 
desde a matéria-prima até o produto final.

O estado atual representa como a empresa se encontra no momento da análise. Devese representar o cliente no canto direito da folha, adicionar todos os processos e incluir o fornecedor das principais matérias-primas. Em seguida, acrescenta-se o fluxo de informação e os lead times de cada processo que foi adicionado.

Sobre a atividade de desenhar o Mapa do Estado futuro, Rother e Shook (2003) propõem um conjunto de questões, enumeradas a seguir, que devem ser respondidas para auxiliar no desenvolvimento do mapa.

a) Levantar o Takt Time: É o ritmo da produção, que é calculado usando o tempo de trabalho disponível para a produção e dividido pela demanda do período que se está avaliando. Este número é utilizado para sincronizar a produção, ou seja, definir qual o intervalo de tempo no qual se deve produzir uma unidade.

b) Definir se a produção será para supermercados ou para expedição: Faz-se uma consideração para o tipo de produção. Em determinados casos, como, por exemplo, na política Make-to-Order, somente é possível produzir para expedição.

c) Levantar as partes do processo nas quais o fluxo contínuo pode ser aplicado: Sempre que possível, utiliza-se o fluxo contínuo como forma de diminuir os estoques em processamento e, consequentemente, reduzir o tempo que o produto fica parado sem a ação de algum processo que agrega valor.

d) Observar onde deverá ser utilizado supermercado para puxar a produção: Recomenda-se instalar supermercados de materiais nos locais em que não foi possível estabelecer o fluxo contínuo para controlar a produção. Sendo assim, o processo fornecedor enviará materiais apenas quando necessário e na quantidade necessária.

e) Definir em que parte da cadeia produtiva a produção será programada: O processo puxador é único na cadeia produtiva e tem a função de ditar o ritmo de produção dos demais processos. Geralmente, trata-se de um processo próximo ao final da cadeia.

f) Nivelar o mix de produção no processo puxador: Esta etapa tem como objetivo distribuir a produção de diferentes produtos de forma homogênea no processo puxador, ou seja, alternar ao longo do dia o máximo possível a produção dos diferentes produtos. Isto auxilia a diminuir os estoques, uma vez que um produto 
não fica muito tempo sem ser produzido.

g) Nivelar o volume de produção: Esta prática consiste em criar uma puxada inicial, retirando somente um pequeno e uniforme incremento de trabalho no processo puxador. O incremento é chamado de pitch e é calculado pela multiplicação do takt time pela quantidade de produtos padronizada em uma embalagem.

h) Desenvolver a habilidade de produzir toda peça todo dia: É fundamental que se desenvolva procedimentos que reduzam o tempo de setup para que seja viável esse tipo de produção. Apesar das dificuldades de aplicação, esse procedimento gera benefícios, como a redução de estoques de produtos acabados e a capacidade de adaptação às mudanças de cenário, como um aumento ou diminuição de demanda, de forma mais rápida e eficaz.

Após mapear o estado futuro, é importante que sejam tomadas ações para implementálo o mais rápido possível, utilizando um plano com metas, datas e responsáveis a fim de garantir o sucesso do projeto. De acordo com Saia (2009), é comum que as implementações sejam realizadas através de eventos Kaizens.

\subsubsection{SMED - Diminuição do tempo de Setup}

Conforme comentado anteriormente, a redução ou a adequação do tempo de setup se faz mandatória para que se possam aplicar as ferramentas da manufatura enxuta. Existem três razões principais para que se despenda esforço para alcançar a redução do setup: o aumento na flexibilidade do sistema e redução de estoques, viabilizando a produção de pequenos lotes; a otimização de gargalos, aumentando, assim, a capacidade produtiva; e a redução de custos como consequência da utilização mais eficiente das máquinas.

Uma técnica conhecida para se alcançar a redução do tempo de setup é o SMED, iniciais de "single-minute exchange of die". Sugai, McIntosh e Novaski (2007) comentam sobre os estágios para o desenvolvimento da metodologia:

a) Separar setup interno e externo: devem-se classificar as atividades de acordo com suas características e separá-las de acordo com a classificação. Setups internos são aquelas realizadas com a máquina parada, sem produzir ou agregar valor; setups externos são as atividades que podem ser realizadas enquanto a máquina ainda está em atividade.

b) Converter setup interno em setup externo: após a conclusão da primeira etapa é 
necessário que se faça um esforço para converter o setup interno em setup externo.

c) Melhorar cada operação de setup, tanto interno quanto externo: após determinar todas as atividades que podem ser feitas enquanto a máquina está em funcionamento, é necessário melhorar todos os processos em busca do ótimo local.

\subsubsection{Trabalho Padronizado}

Os elementos decisivos, como o tempo de ciclo, a sequência da operação ou a aferição da máquina antes de iniciar o trabalho, devem ser mensuráveis e padronizados. Estes modelos devem ser ampliados a todos e é obrigação da administração acompanhar se os mesmo estão sendo cumpridos. Segundo Dennis (2008), alguns pontos primordiais que devem ser considerados:

a) Não há uma única forma de efetuar um trabalho;

b) Os colaboradores precisam planejar o trabalho;

c) A finalidade do trabalho padronizado é prover bases para melhorias.

O trabalho padronizado, segundo Liker (2005), é fundamentado em três elementos, a saber: o takt time (tempo exigido para concluir um trabalho no ritmo da demanda do cliente), a sequência de processos e o quanto de inventário ou estoque cada operário necessita ter em mãos com a finalidade de atingir determinado trabalho padronizado.

Todos os postos de trabalho possuem seus próprios padrões de desempenho e seus próprios Procedimentos Operacionais Padrões (POP), que abarcam todos os colaboradores, processos e máquinas. Sempre que forem encontradas dificuldades, as mesmas devem ser avaliadas e então resolvidas. É preciso ressaltar que a definição do procedimento é resultado de um consenso entre as pessoas envolvidas, porém o cumprimento torna-se obrigatório. Neste aspecto, sua utilização envolve treinamento das pessoas, verificação contínua e controle constante.

Liker (2005) menciona que na Toyota o trabalho padronizado é criado à parte e separado do operador, que é treinado utilizando esse trabalho padronizado, mas o mesmo precisa conseguir efetuar a tarefa sem a necessidade de utilizar o POP. O Procedimento Operacional Padrão, seja técnico ou gerencial, é a base para a padronização de suas tarefas e, com isso, garantir a seus usuários um serviço ou produto livre de variações indesejáveis na sua qualidade final. 
O POP, portanto, é uma ferramenta de gestão da qualidade que busca a excelência na prestação do serviço, procurando minimizar os erros nas ações rotineiras. É uma ferramenta dinâmica, passível de evolução, que busca profundas transformações culturais na instituição, nos aspectos técnicos e políticos-institucionais.

\subsubsection{Heijunka - Nivelamento da Produção}

Heijunka, ou nivelamento da produção, é um conceito relacionado à programação da produção, sendo que um programa nivelado é obtido pelo sequenciamento dos pedidos. $\mathrm{O}$ Heijunka converte a instabilidade da demanda dos clientes em um nivelado e previsível processo de manufatura, e é geralmente usado em combinação com outras técnicas da manufatura enxuta para estabilizar o fluxo de valor. Esse importante conceito ajuda a adequar a estabilidade do processo de manufatura com a demanda do cliente.

Para o nivelamento da produção propõem-se algumas técnicas ou ferramentas, tais como a utilização de pequeno lote, que reduz o tempo de preparação, a sincronização das operações, as linhas de produção em U e a multifuncionalidade dos operadores visando eliminar o desperdício e os gargalos de produção. Portanto, heijunka é o nivelamento das quantidades e tipos de produtos. A programação da produção através do heijunka permite a combinação de diferentes itens a fim de garantir um fluxo contínuo de produção, nivelando também a demanda dos recursos de produção. O heijunka, da forma como é utilizado na Toyota, permite a produção em pequenos lotes e a minimização dos inventários. Este sistema origina uma subdivisão de lotes mesmo que seja possível uma produção com a união deles e, além disso, permite que o volume de produção se mantenha (GALGANO, 2003). Segundo Galgano (2003), as suas vantagens são:

a) Uma maior rapidez na satisfação da procura dos clientes;

b) Diminuição de stocks;

c) Menor ocupação dos armazéns;

d) Permite fabricar ao mesmo tempo grandes quantidades de produtos diferentes.

\subsection{MANUFATURA ENXUTA E TECNOLOGIA DA INFORMAÇÃO}

A aplicação da tecnologia da informação (TI) e os princípios da manufatura enxuta têm sido vistos como mutuamente exclusivos. Defensores da manufatura enxuta têm a ideia 
de colocar em prática um sistema de gerenciamento de informações simplificadas, pois consideram que as organizações com base em fluxo contínuo devem limitar as necessidades de informação para a comunicação local, a montante e a jusante, entre unidades de produção. Sendo assim, é preferível que os funcionários procurem a informação desejada, como e quando necessitarem, ao invés de configurar o software para fornecer-lhes informações repetitivas. Womack, Jones e Roos (1992) afirmam que acumular informações em um grande inventário é tão ruim - talvez pior - do que se acumular grandes estoques de produtos.

As informações devem ser enviadas em pequenos lotes em alta frequência, ao invés de grandes lotes com pouca frequência. As falhas do sistema devem ser visíveis imediatamente, de modo que elas possam ser tratadas diretamente. Sistemas manuais - como o sistema de Kanban, o cabo Andon e outros - são mais adequados, porque eles são mais difíceis de ignorar e por forçar uma ação imediata.

Por outro lado, Riezebos, Klingenberg e Hicks (2009) mencionam que as abordagens da manufatura enxuta e TI são cada vez mais interdependentes e complementares. A abordagem da manufatura enxuta em mix de produto, bens de produção compartilhada e cenária de demanda volátil estão longe do ideal. A utilização de cartões kanban e placas heijunka tornam-se incontroláveis. Calculo da matéria-prima, material em processo, estoques de produtos acabados etc. já não se baseiam em regras muito simples e dados experimentais. Neste ponto, a TI representa um importante suporte para a execução da manufatura enxuta de forma eficaz.

\subsubsection{Sistemas ERP e a manufatura enxuta}

A revisão histórica mostra que os sistemas MRP, MRPII e ERP evoluíram com base nas necessidades das empresas, em modelos de planejamento, programação e controle da produção e de gestão de estoques e nas potencialidades disponibilizadas pela TI. Os ERP caminharam na direção de tornarem-se cada vez mais sistemas integrados de gestão empresarial (um produto focado em TI), afastando-se da proposta inicial dos MRP, fundamentalmente direcionados para a resolução de problemas específicos da manufatura. A evolução continua em curso, de forma que se deve esperar uma abrangência ainda maior nas futuras versões dos sistemas ERP.

Um sistema ERP pode ser definido como um software de negócio que permite à empresa automatizar e integrar a maioria de seus processos. Além de compartilhar práticas de negócio e dados comuns pela empresa, disponibilizando a informação em tempo real. Os 
sistemas ERP são capazes de integrar toda gestão da empresa, agilizando a tomada de decisão. Além disso, podem se adaptar a qualquer tipo de empresa, permitindo monitoramento instantaneamente.

Os sistemas ERP integram módulos/subsistemas de informação de diversas necessidades de um negócio, bem como vendas, contabilidade, compras etc. Com isso, o objetivo é eliminar o uso de interfaces manuais ao utilizar um banco de dados único, aperfeiçoar o fluxo da informação e a confiabilidade da mesma dentro da organização, eliminar a redundância de atividades e interligar os processos de negócio. Cada usuário do ERP depende dos demais para o bom funcionamento do sistema como um todo e, consequentemente, o relacionamento entre os departamentos passa a ser mais constante e intenso. Quando, por exemplo, um cliente faz um pedido, os dados fluem automaticamente para todas as áreas da empresa que serão afetadas, tais como produção, logística, contabilidade (LAUDON, K.; LAUDON, J., 2010).

A Figura 4, a seguir, apresenta a arquitetura de um sistema ERP e os módulos mais comuns em empresas industriais. Os módulos são conjuntos de funções que podem ser adquiridos e implementados separadamente. A divisão em módulos permite que a empresa instale somente aqueles que sejam de seu interesse ou separe melhor as etapas de implementação e alocação de especialistas em cada módulo.

Figura 4 - Arquitetura de um sistema ERP

Fonte: Souza, 2000.

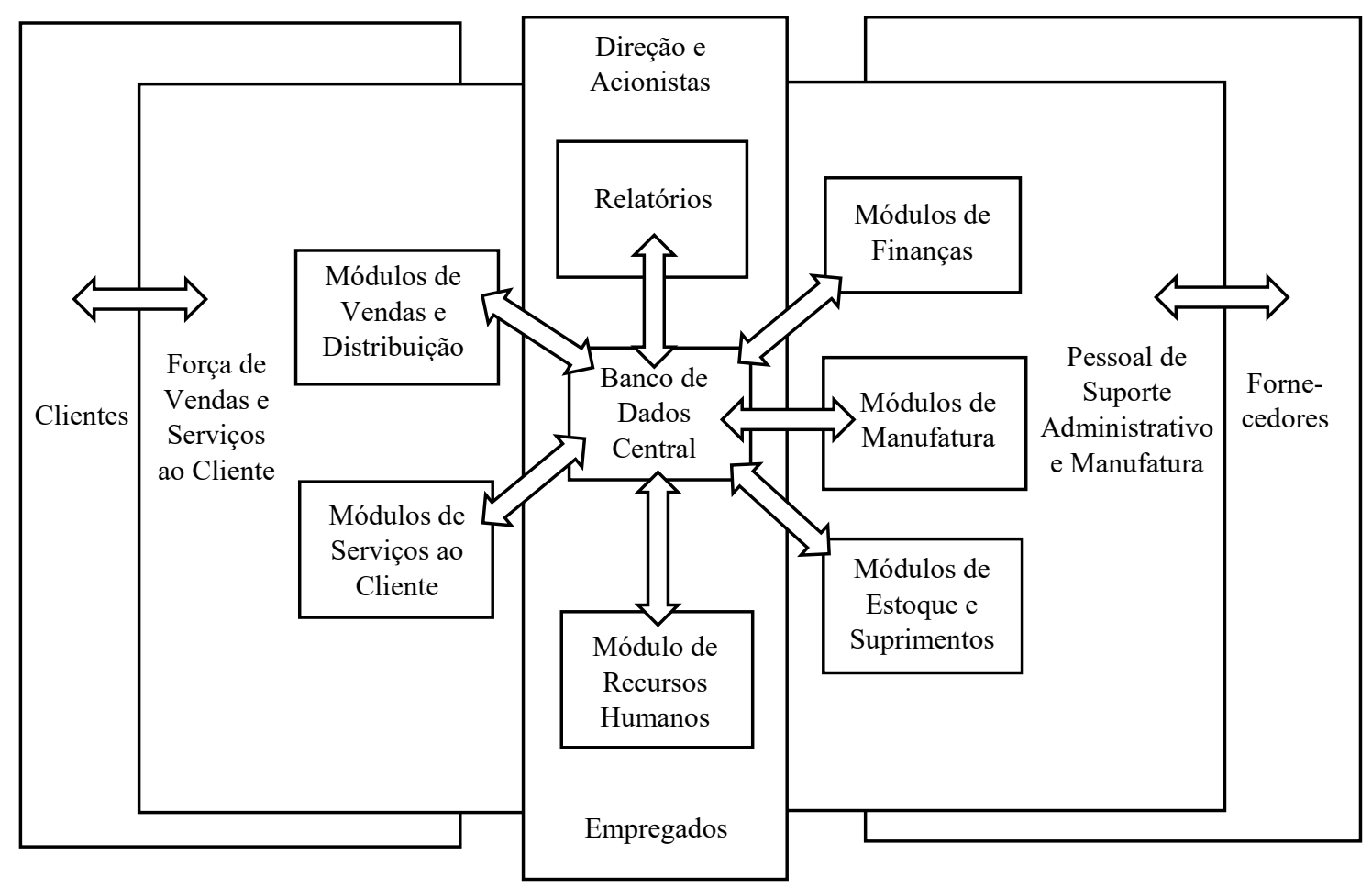


A manufatura enxuta e os sistemas ERP são considerados duas das estratégias utilizadas em empresas com o objetivo de melhorar seu desempenho. Os autores Powell e Strandhagen (2011) discutem o paradoxo entre os sistemas ERP e a manufatura enxuta, conforme mostra o Quadro 2.

Quadro 2 - Resumo do paradoxo entre a manufatura enxuta e ERP

\begin{tabular}{|c|c|}
\hline Manufatura Enxuta & ERP \\
\hline $\begin{array}{c}\text { Produção baseada no consumo (puxada) } \\
\text { Controle descentralizado e capacitação (abordagem } \\
\text { de baixo para cima) }\end{array}$ & $\begin{array}{c}\text { Produção baseada em previsões e utilização de } \\
\text { máquinas (empurrada) }\end{array}$ \\
\hline $\begin{array}{c}\text { Planejamento e controle centralizados (abordagem de } \\
\text { cima para baixo) }\end{array}$ \\
\hline $\begin{array}{c}\text { Produção de modelos diferentes baseados na } \\
\text { freque }\end{array}$ & $\begin{array}{c}\text { Produção em lotes defasados no tempo } \\
\text { Se concentra em manter o fluxo de materiais }\end{array}$ \\
\hline
\end{tabular}

Fonte: Powell e Strandhagen, 2011.

Segundo Womack, Jones e Roos (1992), um verdadeiro sistema de manufatura enxuta, que funcione rigorosamente a cada passo e que nivele a demanda do cliente, provou ser um grande desafio para a maioria das empresas. Black (1998) mostra que o controle de produção por meio dos roteiros operacionais disponibiliza informações aos operadores do sistema de manufatura identificando de onde o material vem, para onde deve ir, quando deve ir e a quantidade necessária a produzir, são roteiros que, além de disponibilizarem informações, controlam o sistema de manufatura.

Alguns sistemas ERP estão oferecendo ferramentas da manufatura enxuta, como, por exemplo, a possibilidade de utilização integrada do Kanban Eletrônico, que permite a sinalização imediata da demanda real do cliente em toda a cadeia de fornecimento. Wan e Chen (2007) descrevem um sistema Kanban baseado na web para envio de dados, rastreamento e monitoramento de desempenho. Muitas empresas têm implementado sistemas de Kanban Eletrônico (e-Kanban) em substituição ao tradicional. Esse sistema tem como um de seus principais objetivos eliminar problemas comuns à utilização do sistema físico de Kanban, como a perda de cartões e a atualização dos quadros. Este é um mecanismo que funciona bem em um sistema de produção em série, pois, uma vez que surge um pedido não previsto ou ocorra uma demanda emergencial, há um impacto em todo o processo.

Soluções de TI enxutas também podem se conectar com os fornecedores, por exemplo, para incluí-los em laços de Kanban. As disposições legais em setores regulados (como as 
indústrias de alimentos e as farmacêuticas) exigem a funcionalidade de rastreamento para associar cada produto acabado com suas matérias-primas e etapas de processamento. Sem suporte de TI, essa tarefa seria impossível. O fator humano desempenha um papel crucial quando se trata de processar melhorias e ainda para mantê-las; a Tecnologia da Informação, por sua vez, é vista como um facilitador das melhorias implementadas. Bell (2005) a descreve como a solução ideal para fazer cumprir os procedimentos de trabalho padrão e Ward e Zhou (2006) concluem que a integração de TI facilita a aplicação e a utilização de práticas JIT.

\subsubsection{Sistemas MES e a manufatura enxuta}

De acordo com Cottyn et al. (2011), os sistemas MES foram idealizados para dar suporte às práticas de manufatura enxuta. Na década de 1990, a MESA (Manufacturing Execution Systems Association) (MEYER, 2009) realizou diversas pesquisas em mais de 100 empresas de diferentes ramos de atividade que tinham um sistema MES funcionando adequadamente em suas instalações para avaliar os benefícios trazidos por esse sistema.

O MES é uma ferramenta desenhada e construída para a manufatura e é utilizada para complementar a funcionalidade dos MRPII/ERP. Ou ainda, de acordo com a definição de Sedano et al. (2011), trata-se de um sistema da tecnologia da informação que é usado para o gerenciamento e planejamento de recursos, equipamentos, empregados e inventário. Muitas vezes, esse sistema integra as operações de chão de fábrica com o Enterprise Resource Planning (ERP).

Nas últimas décadas, as informações detalhadas sobre o que ocorria na produção, os problemas e como resolvê-los, questões de investimentos, quando e quem treinar, ficavam “escondidas" nos dados da produção. O único recurso que o Diretor ou Gerente da produção utilizava para gerenciar era o Excel (software da Microsoft). Essa foi a razão do surgimento dos sistemas MES, ou seja, para saber se o que foi planejado está sendo executado ou não, permitir informações do porquê, onde estão os problemas, quais são as paradas que mais ocorrem, onde investir, quem precisa ser treinado etc. O MES acompanha desde o início da fabricação, através de uma Ordem de Produção (OP), e termina com o produto acabado, detalhando ao máximo todo o processo da produção. Os dados reais baseados em histórico da produção são armazenados por ele e apresentados em forma de relatórios e gráficos, com o objetivo de fornecer informação em tempo real que permita atuar no processo de produção evitando paradas prolongadas e perda de produtividade. 
De acordo com Saenz, Artiba e Pellerin (2009), a estrutura interna tradicional da maioria das soluções MES é concebida de forma modular, de modo que cada sistema pode ser configurado e integrado como desejado, o que eleva o grau de complexidade da análise das operações de fabricação. A codificação desse sistema é realizada de forma personalizada, levando em conta tamanho da empresa, o setor de fabricação, a estratégia de fabricação e os padrões de procedimentos operacionais. A obtenção de um sistema ideal pode gerar custos excessivos de manutenção e exigir reconfiguração ou adaptação do sistema no futuro.

O MES é um sistema que trabalha em conjunto com ERP, trocando informações; contudo, ele é um sistema à parte, ou seja, um sistema híbrido formado por software e hardware que gera informações de histórico e em tempo real e que precisa estar em operação 24 horas por dia.

Segundo Hwang (2006) e Saenz, Artiba e Pellerin (2009), a chave para o sucesso na implantação e manutenção da manufatura enxuta pode ser encontrada na capacidade do fabricante de realmente mudar um processo. Muitas empresas procuram uma série de abordagens rápidas que proporcionam benefícios de curto prazo, mas que não são sustentáveis a longo prazo. É por essa razão que as iniciativas enxutas falham. O sistema MES deve ser flexível o suficiente para acomodar a filosofia de melhoria contínua de um ambiente enxuto, ou seja, um sistema de melhoria contínua depende de feedback. Devido à sua disponibilidade em tempo real de dados, o MES é visto como a melhor ferramenta para medir os indicadores de desempenho em tempo real, tais como o uso de materiais, tempos de processo e quebra de máquinas.

Ao implementar um sistema MES, todos os processos devem ser minunciosamente revistos para garantir um fluxo de trabalho ideal, englobando todas as atividades na área de produção, estoque, manutenção e qualidade. Como a manufatura enxuta é um processo de melhoria contínua, esta situação está longe de ocorrer.

O MES oferece aos funcionários, supervisores e gestores de chão de fábrica, painéis visuais em tempo real com foco em indicadores-chave de desempenho (KPI) que podem ser usados para monitorar toda a corporação, as linhas de negócios, funções ou processos. Esses sistemas também podem notificar os usuários imediatamente quando ocorrem condições fora do controle, isso permite que as pessoas que trabalham com a informação identifiquem os problemas e realizem ações corretivas apropriadas.

Segundo Meyer (2009), pode-se afirmar que um sistema MES em funcionamento é uma condição para alcançar os objetivos da Manufatura Enxuta. A coleta de dados em tempo real e a facilidade de acesso a esses dados são necessárias à rápida tomada de decisão. Um 
sistema produtivo, como a Manufatura Enxuta, é altamente dependente da exatidão e atualidade dos dados produzidos e coletados durante os processos de produção. Exemplos incluem o tempo de funcionamento da máquina, tempo de ciclo do processo ou, mesmo, as quantidades de peças produzidas.

Um sistema informatizado de produção em tempo real, principal função do MES, reduz a espera, o estoque e o tempo de transporte pela sincronização dos processos de produção. O MES também garante a padronização dos processos, uma vez que os operadores são guiados com informações eletrônicas que contribuem significativamente para a melhoria da produtividade (MEYER, 2009). Além disso, desvios são imediatamente reconhecidos pelo controle em tempo real de todo s os parâmetros que influenciam no processo de produção; nesse sentido, medidas podem ser tomadas conforme a necessidade.

\subsubsection{Inteligência Empresarial: Business Intelligence (BI)}

Num primeiro momento, a maior parte das implantações de sistemas empresariais restringiu-se ao uso do ERP em nível operacional, com poucas contribuições gerenciais e estratégicas, mas atualmente já é mais comum que as soluções empresariais contemplem ferramentas de inteligência empresarial (Business Intelligence), que apresentam visão agregada multidimensional do negócio (GONÇALVES; RICCIO, 2009).

Business Inteligence é um conceito que envolve a utilização de produtos e soluções com tecnologia analítica pronta, que permite transformar dados armazenados em bases de dados de informações e auxilia os diversos níveis de uma empresa na tomada de decisões. As ferramentas de Business Inteligence oferecem uma visão ampla do negócio e ajudam na distribuição uniforme dos dados entre os usuários, sendo seu objetivo principal transformar grande volume de dados em informação de qualidade para os tomadores de decisão. Através delas é possível cruzar dados, visualizar informações em várias dimensões e analisar os principais indicadores de desempenho empresarial.

Não há dúvidas de que os sistemas transacionais, como os ERP (Enterprise Resource Planning - sistemas de gestão empresarial), os CRM (Customer Relationship Management gerenciamento do relacionamento com o cliente) e o Supply Chain (Gerenciamento da Cadeia de Valor), entre outros, são fontes preciosas e inesgotáveis de dados, no entanto, para que sejam úteis, é preciso transformá-los em informação. Dentro desse contexto, cresce o interesse pelo que se chama de Business Intelligence - um guarda-chuva que abarca conceitos e uma série de ferramentas que possibilitam trabalhar e organizar os dados, captados através de 
diferentes sistemas, tornando-os consistentes, não redundantes e capazes de adicionar inteligência aos negócios, resultando em maior agilidade para as decisões gerenciais. (SOUZA; ZWICKER, 2001).

O BI veio suprir a busca por sistemas analíticos para lidar com um grande volume de dados e gerar informações significativas para a tomada de decisão, uma vez que os sistemas transacionais, como os ERP, foram concebidos para registrar e processar as transações de negócios, possibilitando um escopo limitado de relatórios pré-definidos para acompanhar as transações (CHOU; TRIPURAMALLU, 2005).

Observa-se, portanto, que ERP e BI se complementam e a integração destes é benéfica em termos de análises de negócio. Apesar de o ERP dispor de alguns relatórios que apresentam a situação recente ou em tempo real de transações, o BI é necessário para consultas ad hoc, projeções e relatórios mais flexíveis. Mesmo para dados operacionais, o BI auxilia em análises mais abrangentes que podem, inclusive, se refletir nos processos que ocorrem no ERP, como, por exemplo, análises de preços de compras no BI podem levar à revisão do processo de compras que ocorre no ERP (CHOU; TRIPURAMALLU, 2005).

Segundo White (2006), apesar da maioria das soluções de BI enfatizarem sua aplicação em análises dos tipos estratégicas e táticas que são mais voltadas ao médio e longo prazo, com a difusão dos sistemas de informações nas organizações, o BI pode ser também do tipo operacional e voltado para análises das atividades diárias.

Quadro 3 - Comparação entre BI estratégico, tático e operacional

\begin{tabular}{|c|c|c|c|}
\cline { 2 - 4 } \multicolumn{1}{c|}{} & BI Estratégico & BI Tático & BI Operacional \\
\hline Foco & $\begin{array}{c}\text { Alcançar metas de longo } \\
\text { prazo }\end{array}$ & $\begin{array}{c}\text { Atuar em iniciativas } \\
\text { alinhadas com a estratégica }\end{array}$ & $\begin{array}{c}\text { Gerir e otimizar operações } \\
\text { diárias }\end{array}$ \\
\hline Usuários Principais & $\begin{array}{c}\text { Executivos e analistas de } \\
\text { negócio }\end{array}$ & $\begin{array}{c}\text { Gerentes, analistas de } \\
\text { negócios, coordenadores }\end{array}$ & $\begin{array}{c}\text { Coordenadores, usuários } \\
\text { operacionais, sistemas } \\
\text { relacionados às operações }\end{array}$ \\
\hline Período de análise & Meses a anos & Dias, semanas a meses & $\begin{array}{c}\text { Diário ou mesmo em tempo } \\
\text { real }\end{array}$ \\
\hline Tipo de dados & $\begin{array}{c}\text { Indicadores-chave / } \\
\text { métricas históricas }\end{array}$ & Métricas históricas & $\begin{array}{c}\text { Métricas pontuais e } \\
\text { recentes }\end{array}$ \\
\hline
\end{tabular}

Fonte: Autor "adaptado de" White, 2006. 


\subsubsection{Alinhamento Estratégico de TI}

Modelos são aproximações da realidade desenvolvidas pelo Homem. Assim, o modelo, aqui apresentado, deve ser visto como tentativa, baseada em conhecimentos e métodos científicos, de retratar os meios para alcançar o alinhamento estratégico de TI nas organizações.

O modelo de Henderson e Venkatraman (1993) possui quatro domínios fundamentais: Estratégia de Negócio, Estratégia de TI, Infraestrutura e Processos Organizacionais, e Infraestrutura e Processos de TI (Figura 5). Na visão desses autores, a estratégia de negócios envolve formulação (escolhas sobre abordagem competitiva, produtos e mercados) e implementação (decisões sobre a estrutura e as capacidades que irão executar as escolhas de produtos e mercados). Da mesma forma, a estratégia de TI deve envolver escolhas sobre os tipos de tecnologias da informação a serem empregadas e seus meios de utilização e de aquisição (formulação), bem como decisões de como a infraestrutura de TI deve ser configurada e gerenciada (implementação).

Figura 5 - Modelo de Henderson e Venkatraman Fonte: Henderson e Venkatraman, 1993.

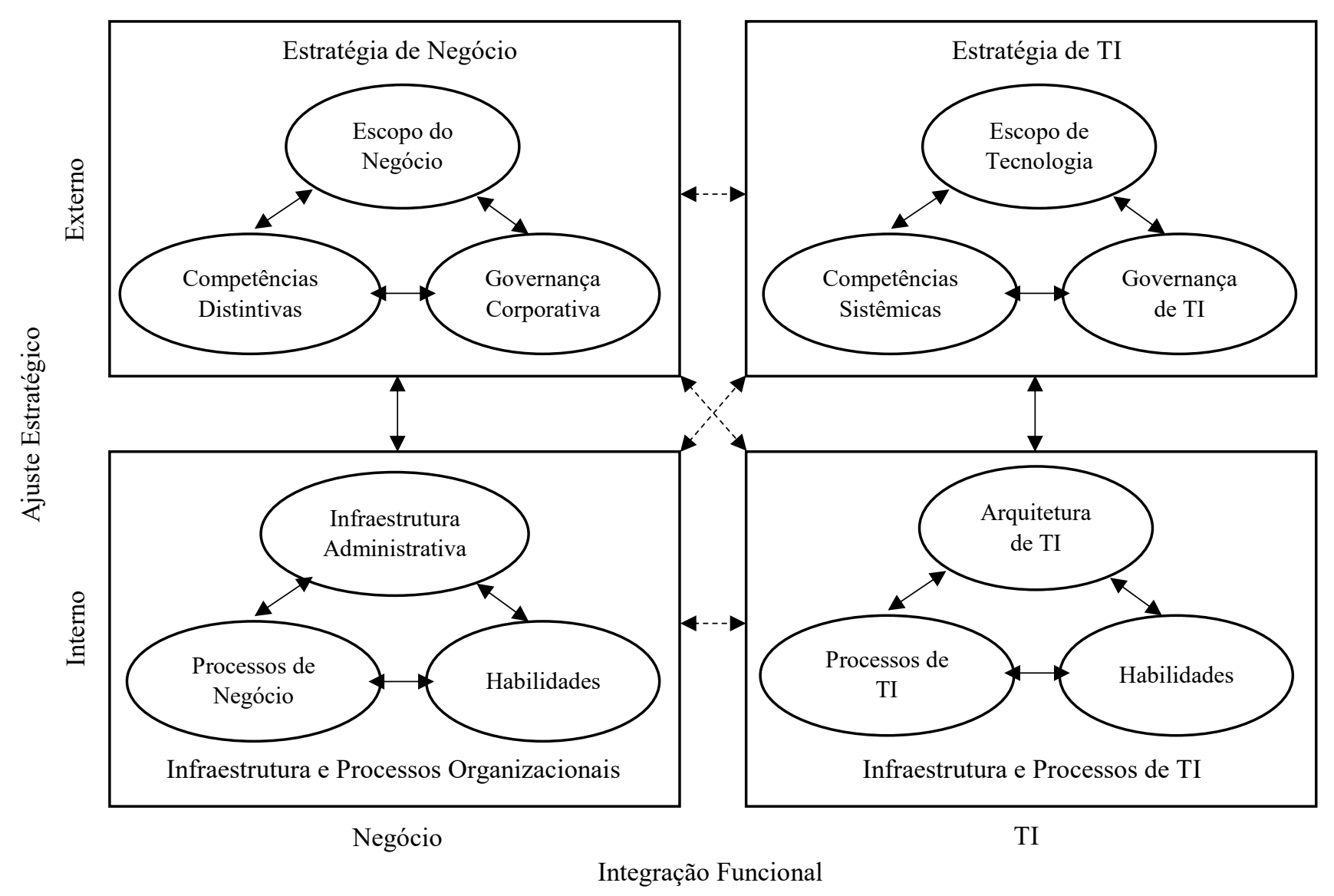


Henderson e Venkatraman (1993) afirmam que o alinhamento estratégico de TI é baseado em: (1) ajuste estratégico entre o posicionamento da organização e de TI no mercado (ambiente externo) e a infraestrutura administrativa adequada para suportar tal posicionamento (ambiente interno), e (2) integração funcional entre os domínios de negócio e de TI, tanto no nível estratégico quanto de infraestrutura e processos.

Os autores sustentam que o Alinhamento Estratégico de TI não é um evento, mas um processo contínuo de adaptação e mudança, e que, para alcançá-lo, é necessária uma substancial mudança no pensamento gerencial sobre o papel da TI na organização, assim como um entendimento da estratégia de TI e de sua importância, tanto no suporte como no direcionamento das decisões de estratégia de negócios. Eles não associam diretamente o alinhamento estratégico de TI com o desempenho organizacional, mas afirmam que a falta de alinhamento é uma das causas dos questionamentos sobre os resultados dos investimentos feitos em TI.

O modelo que Henderson e Venkatraman (1993) desenvolveram atende a lógica, a abrangência e os padrões de transformações organizacionais relacionados com a tecnologia da informação. Assim, esse modelo deriva-se em quatro perspectivas de alinhamento estratégico de TI, conforme descrito a seguir:

a) Execução da Estratégia, quando a estratégia de negócios define a infraestrutura e processos organizacionais, produzindo, também, os requisitos de infraestrutura e processos de TI. Esta é a perspectiva mais difundida e melhor compreendida, uma vez que corresponde ao modelo clássico de visão hierárquica de administração estratégica.

b) Transformação Tecnológica, que implica o desenvolvimento de uma estratégia de TI em resposta a uma estratégia de negócios. A infraestrutura e os processos de TI são elaborados a partir desses requerimentos. Nesta perspectiva, nota-se que a estrutura de TI não é restringida pela estrutura da organização de negócios.

c) Potencial Competitivo, que explora novas características e potencialidades da TI, redefinindo a estratégia de negócios e, em consequência, a infraestrutura e os processos organizacionais. A escolha da estratégia de negócios decorre de uma nova estratégia de TI adotada. 
d) Nível de Serviço, foca em produzir uma organização de TI que seja considerada de "classe mundial"; o alinhamento estratégico de TI é proveniente da qualidade e quantidade de serviços de TI prestados à organização.

\subsubsection{Sistemas Interorganização (empresa e fornecedor)}

Dentre os níveis de impactos da TI na organização, tem-se o impacto ao nível de processos organizacionais. Para Tallon (2010), a TI influencia, em primeiro plano, os processos inter (relações com fornecedores e clientes, vendas e suporte ao marketing etc.) e intraorganizacionais (operações e produção, melhoria produto/serviço etc.). O impacto ao nível da organização segue o impacto ao nível de processos (TALLON; KRAEMER, 2007).

Há um conjunto de outros fatores que envolvem diretamente a adoção de diversos sistemas, como ERP, MES, sistemas interorganizacionais, e devem ser entendidos, pois podem influenciar diretamente resultados obtidos e até mesmo o alinhamento com as práticas da empresa.

\subsubsection{Capacidade de infraestrutura de TI}

O termo Tecnologias da Informação (TI) pode ser definido como um conjunto de processos cognitivos (softwares) e materiais (hardware) necessários para a realização de uma atividade de captação, processamento, memorização ou emissão de informações. As tecnologias de informação possibilitam não apenas o aumento da eficiência do sistema de informação da empresa, mas permite também obter vantagens competitivas em relação aos concorrentes.

Para O’Brien (2002), as tecnologias de informação englobam, cada vez mais, não apenas o componente de informática tradicional (hardware e software), mas também a gestão de base de dados e os sistemas de telecomunicações de redes. De acordo com Laudon e Laudon (2010), a infra-estrutura de TI está composta por cinco elementos principais: hardware, software, tecnologias de gestão de dados, tecnologias de redes e telecomunicações e serviços de tecnologia. Assim, o investimento em TI poderá envolver a aquisição de hardware, software, serviços de comunicação ou serviços de desenvolvimento de soluções, seja recorrendo a recursos internos e/ou a fornecedores externos (outsourcing), com o objetivo de melhorar o sistema de informação de uma organização. 
Segundo Laudon e Laudon (2010), a infraestrutura de hardware consiste na tecnologia para processamento computacional, armazenamento, entrada e saída de dados. Ainda seguindo os autores, esse componente inclui grandes mainframes, servidores, computadores de médio porte, computadores pessoais e laptops, assistentes digitais pessoais de mão e dispositivos móveis que dão acesso a dados coorporativos e internet. Inclui, também, equipamentos para reunir e registrar dados, meios físicos para armazenar os dados e dispositivos para a saída da informação processada.

$\mathrm{Na}$ maior parte dos casos, essa tecnologia agiliza e facilita as rotinas e tarefas tanto pessoais como organizacionais, tornando-se relevante ao atendimento de clientes, fornecedores, parceiros de negócios, funcionários e acionistas (HABERKAMP et al., 2010).

Para Bharadwaj (2000), a infraestrutura de TI representa a base de entrega de informação compartilhada, a funcionalidade do negócio definida em termos de alcance (locais de acesso e link da plataforma) e extensão (tipo de informação compartilhada). Essa noção de infraestrutura precisa ser abordada na perspectiva das capacidades que, portanto, são complexas socialmente, relacionadas a outros recursos/capacidades e inerentes ao contexto da organização (HARTONO et al., 2010).

\subsection{MANUFATURA ENXUTA E SUA MEDIÇÃO DE DESEMPENHO}

$\mathrm{O}$ artigo "Lean and performance measurement", de Sanjay Bhasin (2008), analisa a necessidade das organizações de adotarem uma abordagem que procura compreender os fenômenos na sua totalidade e globalidade de forma abrangente para medição de desempenho. O balanced scorecard (KAPLAN; NORTON, 1992, 1993) foi o impulso para este ponto de vista e, juntamente com o trabalho de Dimancescu, Hines e Rich (1997), fornece a base para uma posterior análise (MALTZ; SHENHAR; REILLY, 2003). Os benefícios da manufatura enxuta nem sempre são óbvios quando a metodologia contábil tradicional é utilizada, mas, essencialmente, é através da gestão e melhoria de processos aliados às relações de clientes e funcionários que a perspectiva financeira avançará em conformidade.

De acordo com a literatura, vários fatores têm contribuído para o debate sobre os sistemas de medição de desempenho:

a) Sistemas de contabilidade tradicionais alocam despesas gerais com base na mão de obra direta (NEELY; GREGORY; PLATTS, 2005). Eram muito apropriados na década de 1960, quando a mão de obra direta era constituída de mais de 50 por 
cento do custo das mercadorias vendidas; contudo, já na década de 1990, ela raramente ultrapassava os 5 por cento.

b) O aumento da concorrência global se concentrava em serviço, flexibilidade, personalização e inovação (WOMACK; JONES, 1996).

c) Variação das demandas externas em que os clientes buscam altos níveis de serviço e as empresas operam de forma identificável. A Ford, por exemplo, exigia que seus fornecedores credenciados introduzissem um esquema conhecido como sistema operacional de qualidade, que é, essencialmente, um processo de medição de desempenho (NEELY, 1999).

No entanto, as métricas tradicionais não funcionaram, porque:

a) Medidas contábeis tradicionais não são adequadas para as decisões estratégicas (KAPLAN; NORTON, 2005);

b) Métricas tradicionais são históricas e difíceis de se correlacionar (LAWSON; STRATTON; HATCH, 2003);

c) Elas fornecem pouca informação sobre a raiz dos problemas (MALONE; SINNETT, 2005);

d) A ligação entre medidas financeiras e não financeiras é frágil (MARSHALL; HEFFES, 2004);

e) Pouca atenção é dada aos processos multifuncionais em oposição aos funcionais (FRIGO, 2003);

f) Ativos intangíveis requerem modesta atenção (LAWSON; STRATTON; HATCH, 2003; SHAH; WARD, 2003);

g) Elas ignoram a criação de valor (BICHENO, 2004; WOMACK; JONES, 1996);

h) Elas incentivam os gestores a minimizar as variações em vez de procurar ativamente a melhoria continua (WOMACK; JONES, 1996); e

i) Muito raramente podemos agregar do operacional para níveis estratégicos (YENIYURT, 2003; MALTZ; SHENHAR; REILLY, 2003).

Existem algumas organizações que precisam direcionar seus esforços para implementar um sistema de medição de desempenho eficaz. O desafio é escolher as medidas certas para o nível adequado da organização. Se inapropriadamente planejado, as medidas podem ser contrárias à estratégia e incentivar o tipo errado de comportamento. Nos estágios 
iniciais de um negócio de alta tecnologia, por exemplo, os gerentes se concentram em confiabilidade, velocidade e eficiência. $\mathrm{Na}$ fase de crescimento, a principal medida é a participação do mercado, alternando com os setores maduros, preço, custo de produção e utilização da capacidade. Se considerarmos uma indústria envelhecida, as respectivas métricas de fluxo de caixa muitas vezes começam a ter prioridade.

Existem três classes de medidas de desempenho (TANGEN, 2005). A classe mais baixa lembra o sistema tradicional concentrado nas finanças enquanto que o próximo nível instiga uma visão mais equilibrada. O nível mais alto utiliza a tecnologia da informação vigente e procura relações causais em toda a organização. Portanto, as empresas precisam adotar medidas que facilitam equilibrar as pressões externas (a satisfação do cliente) em conjunto com as pressões internas (satisfação do empregado).

Da mesma forma, é fundamental medir o que é importante para a empresa. As medidas precisam se concentrar nas estratégias-chave, tais como fluxo de caixa ou de crescimento. Nesse sentido, a organização pode agir. O problema é que muitas organizações não conseguem traduzir metas qualitativas em métricas quantitativas. A relação entre as medidas qualitativas e quantitativas pode não ter sido completamente explorada. Trabalhos realizados pela "Escola de Economia de Estocolmo" (NEELY, 1999) identificaram uma correlação positiva entre a satisfação do cliente e desempenho financeiro.

O maior desafio para muitas organizações continua a ser a necessidade de se alcançar uma mudança cultural, procurando manter o foco nos objetivos, introduzindo novas medidas de desempenho e eliminando as obsoletas (LAWSON; STRATTON; HATCH, 2003). É necessária uma avaliação das medidas contra diferentes critérios que são importantes para a organização (TANGEN, 2005). No entanto, a avaliação de KPI (Key Performance Indicator) pode consumir tempo (MALONE; SINNETT, 2005).

Um dos pré-requisitos é a necessidade de alinhar as métricas com a estratégia. Há ampla evidência (FRIGO, 2003), mostrando que boas e sólidas métricas podem facilitar a implementação de uma estratégia (NEELY; GREGORY; PLATTS, 2005.). Nesse contexto, a implantação de políticas tornou-se um método aceitável para comunicar os objetivos de qualidade e os de produtividade em toda a organização enxuta. Ele é usado pela Toyota e por organizações ocidentais líderes, como a Intel e a Ford. O princípio sugere que, comunicando objetivos comuns da organização, pode-se garantir o compromisso de crescimento. As principais etapas envolvem o estudo da situação atual, as transformações necessárias para mudança e a visão do futuro. Consequentemente, uma visão de 10 por cento de crescimento vai exigir a redução do tempo de execução - utilizando, por exemplo, o método de um 
sistema JIT. Então, verificações contínuas específicas são iniciadas para garantir que os planos locais se somem aos planos gerais.

Muitas vezes as organizações coletam uma quantidade considerável de informações, mas não possuem um sistema eficaz que traduza esses feedbacks em uma estratégia produtiva para a ação. Pesquisas (KAPLAN; NORTON, 2005; NEELY; GREGORY; PLATTS, 2005) são encaminhadas às organizações para utilizarem a tecnologia da informação, como parte de uma avaliação de desempenho. O balanced scorecard (Indicadores Balanceados de Desempenho) de TI ajuda a focar as relações causais dentro da organização e também os gestores a agregar maior valor. Os benefícios são visíveis, é possível automatizar a coleta de dados e produção de relatórios economizando tempo e permitindo aos gestores analisar divergências e questões específicas. Com a melhoria das estruturas de TI é possível implementar os indicadores de nível operacional em medidas de nível corporativo.

Os pesquisadores da manufatura enxuta (WOMACK; JONES, 1996; BICHENO, 2004; LIKER; MEIER, 2006) defendem os seguintes benefícios:
a) Tempo de ciclo mais curto;
b) Prazos mais curtos;
c) Material em processo inferior;
d) Tempo de resposta mais rápido;
e) Menor custo;
f) Flexibilidade de produção maior;
g) Maior qualidade;
h) Melhor serviço ao cliente;
i) Aumento da receita;
j) Maior rendimento; e
k) Aumento de lucro.

Maskell et al. (2011) enfatizam a necessidade de realinhar as metas financeiras com aquelas que a manufatura enxuta tenta realizar. Além disso, centram-se na necessidade de medir o progresso financeiro a partir de uma perspectiva de questões relevantes do negócio e no custo real ao invés do método tradicional do custo padrão. No entanto, observa-se que muitas vezes os benefícios da manufatura enxuta são difíceis de quantificar (WOMACK; JONES, 1996). 
Para construir uma base sustentável para a manufatura enxuta toda a empresa necessita de um roteiro. As medidas de desempenho devem ser escolhidas possibilitando mensurar se está havendo progresso em relação às metas e aos pontos de verificação (marcos). Desse modo, é fundamental para as empresas enxutas implantar sistemas de alerta para sinalizar precocemente os problemas que precisam ser resolvidos.

Cerca de $60 \%$ das organizações afirmam estar utilizando um scorecard (KAPLAN; NORTON, 2005). Sem dúvida, os benefícios reais da manufatura enxuta são difíceis de quantificar. Preparação mais rápida, tempo de ciclo mais curto e melhor gerenciamento visual melhoram o funcionamento de uma fábrica. A filosofia da manufatura enxuta (STANDARD; DAVIS, 2000) enfatiza a eficiência total do sistema. Os benefícios relacionados incluem menor tempo de execução, maior flexibilidade, menor volume de estoque, melhor atendimento ao cliente e aumento das receitas. Sem dúvida, os meios tradicionais de mensuração de resultados através de métodos de contabilidade não incorporam a verdadeira avaliação de ativos intangíveis e intelectuais de uma organização (KAPLAN; NORTON, 1992, 1993). Estes incluem produtos de alta qualidade e serviços, funcionários motivados e qualificados, processos internos mais ágeis e robustos ao lado de clientes satisfeitos e leais. Pesquisas (LAWSON; STRATTON; HATCH, 2003; WOMACK; JONES, 1996) sugerem que os últimos são mais críticos para o futuro a longo prazo da organização.

Apesar da popularidade do balanced scorecard, foi recentemente comprovado sua inadequação em determinadas circunstâncias. O quadro de desempenho multidimensional dinâmico (DMP) (MALTZ; SHENHAR; REILLY, 2003) é multidimensional na natureza, retratando o sucesso como um conceito dinâmico, contínuo, que deve ser analisado por vários períodos de tempo, além de representar vários stakeholders. Cerca de 12 potenciais "medidas iniciais" (MALTZ; SHENHAR; REILLY, 2003) são defendidas em cinco dimensões principais de sucesso: financeiro, mercado, processo, pessoas e futuro.

Em uma tentativa de automatizar o sistema, as medidas financeiras não representam um grande problema, pois têm sido utilizadas de forma eficaz por muitos anos. Por outro lado, as medidas não financeiras são difíceis de estabelecer (ALLIO, 2006). A determinação de medidas de desempenho pode ser um desafio e é vital que os gestores procurarem determinar as relações de causa e efeito da estratégia ao tentar vincular com a medição. 
Quadro 4 - Modelo de desempenho

\begin{tabular}{|c|c|}
\hline Financeiro & $\begin{array}{l}\text { Resultado depois de juros e impostos } \\
\text { Taxa de retorno sobre o capital empregado } \\
\text { Liquidez Corrente } \\
\text { Lucro por ação }\end{array}$ \\
\hline Medidas do cliente/mercado & $\begin{array}{l}\text { A participação de mercado por grupo de produtos } \\
\text { Índice de satisfação do cliente } \\
\text { Taxa de retenção de clientes } \\
\text { A qualidade do serviço } \\
\text { Receptividade (definida pelo cliente) } \\
\text { Entrega no prazo (definida pelo cliente) }\end{array}$ \\
\hline Processo & $\begin{array}{l}\text { Prazo de entrega NPD (new product development) } \\
\text { O tempo de ciclo } \\
\text { Tempo de comercialização de novos produtos } \\
\text { Qualidade de desenvolvimento de novos produtos } \\
\text { Custos da qualidade } \\
\text { Avaliação da qualidade } \\
\text { Defeitos críticos de produtos/componentes } \\
\text { Custos de materiais e de produção } \\
\text { Produtividade do trabalho } \\
\text { Produtividade do espaço } \\
\text { Eficiência Capital } \\
\text { Inventário de matérias-primas } \\
\text { Inventário do produto em processo } \\
\text { Estoque de produtos acabados } \\
\text { Rotatividade do estoque }\end{array}$ \\
\hline Pessoas & $\begin{array}{l}\text { Pesquisas de percepção do empregado } \\
\text { Saúde e segurança por empregado: } \\
\text { acidentes } \\
\text { absentismo } \\
\text { rotatividade } \\
\text { Retenção de funcionários de topo } \\
\text { Qualidade de desenvolvimento profissional/técnica } \\
\text { Qualidade de desenvolvimento da liderança }\end{array}$ \\
\hline Futuro & $\begin{array}{l}\text { Profundidade e qualidade do planejamento estratégico } \\
\text { Antecipar mudanças futuras } \\
\text { Desenvolvimento de novos mercados } \\
\text { Desenvolvimento de novas tecnologias } \\
\text { Porcentagem de vendas de novos produtos }\end{array}$ \\
\hline
\end{tabular}

Fonte: Autor.

Enquanto muitos reconhecem a ligação entre o cliente e a satisfação dos colaboradores, juntamente com o desempenho financeiro, um scorecard pode não fornecer orientações sobre a metodologia para melhorar o desempenho e alcançar os resultados estratégicos desejados. Inegavelmente, qualquer scorecard precisa de ajuste periódico para realinhar alterações estratégicas ou estrutura societária, no entanto, esta é um tanto morosa e cara. Há também problemas de implementação; o tempo total de desenvolvimento é de um ano para um scorecard típico. Consequentemente, nem todas as medidas propostas no modelo podem ser adequadas a qualquer momento e cada empresa deve usar os componentes do 
quadro de maneiras diferentes e com graus diferentes de importância (MALTZ; SHENHAR; REILLY, 2003). O conjunto adequado de medidas depende do tamanho, da tecnologia, da estratégia da empresa, juntamente com as características da indústria e do meio ambiente relevante em que a empresa opera.

O Sistema Toyota de Produção, tal como praticado por Toyota, não pode ser facilmente copiado por outras organizações, devido à variação de alguns processos gerenciais e à cultura dominante. Se aceitarmos que um processo é uma soma de atividades movidas e dirigidas pelo cliente, então qualquer mau desempenho em um elo da cadeia é suficiente para estragar o desempenho global. Sem dúvida, as ramificações do uso de métricas erradas podem ser devastadores.

Da mesma forma, as métricas escolhidas precisam ser alinhadas com as expectativas dos clientes. Nesse contexto, o sistema precisa ser focado para a melhoria contínua com a filosofia da manufatura enxuta. Propõe-se (NEELY; GREGORY; PLATTS, 2005) que deve haver uma reavaliação periódica da adequação do sistema de medição de desempenho estabelecida em resposta ao ambiente competitivo atual.

A literatura (MARSHALL; HEFFES, 2004; TANGEN, 2005) prega cautela, uma vez que a aplicação do Balanced Scorecard requer uma compreensão abrangente dos princípios envolvidos e comprometimento significativo no sentido de aceitar a nova filosofia.

Segundo Brosnahan (2008), a administração de um fluxo de valor (VSM) é um modo diferente de medir e avaliar os resultados de uma companhia e requer mudanças nos processos decisórios. Ao invés de administrar e medir resultados através de departamentos tradicionais, como atendimento ao consumidor, compras, fabricação, contabilidade, dentre outros, uma empresa se organiza em fluxos de valores, administrando e medindo resultados através dos mesmos. Um fluxo de valor inclui todas as funções e pessoas necessárias para apoiar completamente as operações do fluxo de valor. Um líder de fluxo de valor é responsável pelo treinamento global e sua rentabilidade. São identificadas métricas específicas para que o fluxo de valor seja monitorado: entre outras, serão criadas métricas para medir a segurança, qualidade, entrega e custo (SQDC).

\subsubsection{Segurança}

A taxa de incidência pode ser usada para mostrar o nível relativo de lesões e doenças entre as diferentes indústrias, empresas, ou operações dentro de uma única empresa. Ela pode ser calculada ao multiplicar o número de acidentes e doenças de um período por 200.000 
horas e dividir pelo número de horas trabalhadas pelos funcionários no relativo período. As 200.000 horas na fórmula representam o equivalente a 100 funcionários que trabalham 40 horas por semana e 50 semanas por ano.

\subsubsection{Qualidade}

A razão de se estabelecer uma gestão de qualidade é de que o mercado está em constante mutação: os clientes exigem uma nova postura empresarial, os concorrentes estão cada vez mais agressivos e não se limitam apenas ao mercado nacional, a economia e a política estão cada vez mais dinâmicas. Nos dias atuais, a qualidade está no conceito de gerenciamento das empresas, pois não há como sobreviver no mercado sem qualidade (SANTOS et al., 2007).

Alguns dos indicadores que medem o desempenho da área de qualidade são, de acordo com Goldman (2005):
a) Índice de retrabalhos;
b) Quantidade de queixas de garantia e devoluções;
c) Quantidade de defeitos.

\subsubsection{Entrega}

Outro aspecto importante é o tempo que a empresa necessita para responder às necessidades do cliente, para a fabricação do produto final e para entrega de mercadorias. Alguns exemplos de métricas são: tempo de resposta ao cliente, tempo total de ciclo da cadeia de suprimentos, lead time de pedido, lead time de entrega, frequência de entrega, lead time de manufatura, tempo total de resposta da cadeia de suprimentos (SHEPHERD; GÜNTER, 2006).

O tempo de entrega é uma medida de processo que fornece a eficiência da cadeia, ele é obtido pela divisão da quantidade de bens ou serviços entregues aos clientes no prazo pela íntegra dos bens ou serviços entregues. Ele ajuda a determinar a eficiência que está sendo cumprida ou prazos acordados com os clientes. Se o valor for muito baixo, poderá ser usado como um sinal de que em algum lugar, ao longo da cadeia de fornecimento, existem gargalos,

processos demorados ou ineficientes que não estão agregando valor e merecem uma investigação mais aprofundada, ou, ainda, que um método mais lento está sendo 
empregado. É importante lembrar que a manutenção das necessidades do cliente, inclusive aderindo a prazos de entrega, deve ser uma prioridade importante para todos na empresa.

\subsubsection{Custo}

A maior parte das empresas acredita que basta se igualar aos principais concorrentes, quando se trata do preço de venda de seus produtos e serviços, para continuar sobrevivendo. Para que seu negócio sobreviva em meio a tantas ofertas e vantagens que seus concorrentes oferecem para seus clientes, é preciso criar e saber implementar estratégias diferenciadas de preço, por meio da diferenciação e de custos controlados. Esses são atributos que, independentemente do tamanho e da época, uma empresa pode desenvolver gradativamente (LOVELOCK; WRIGHT, 2006).

De uma forma geral, na perspectiva do cliente, o núcleo da estratégia consiste na criação de uma proposição de valor sustentável envolvendo preço, qualidade, disponibilidade dos produtos, sortimento, funcionalidade, serviço, parceria e a imagem da marca. Quando um empresário opta por conquistar o cliente somente na base do preço, ele está praticamente indo em sentido contrário, pois não terá condições nem recursos para defender sua marca. (RABAGLIO, 2006).

Alguns dos indicadores que medem o desempenho da empresa perante o mercado são:

a) Valor do faturamento pelo número de funcionários;

b) Índice de admiração e confiança do cliente perante a empresa;

c) Índice de inovação e variedade de produtos;

d) Tempo de lançamento de novos produtos;

e) Percentual do faturamento obtido com novos produtos;

f) Classificação mercadológica entre os clientes (preferência);

g) Número de reclamações do consumidor;

h) Taxa de êxito nas propostas;

i) Tempo de resposta ao pedido do cliente.

\subsubsection{Inventário}

O inventário representa, muitas vezes, um grande investimento de capital para a empresa, pois certos custos se elevam com níveis de estoques mais elevados (GAITHER; 
FRAIZER, 2006). Shepherd e Günter (2006) destacam, nesse sentido, algumas métricas utilizadas, como os custos de inventário, giro de estoques, precisão do inventário, a utilização de inventário, a capacidade de estoque e o investimento em inventário.

$\mathrm{O}$ giro de estoque calcula o número de vezes que o estoque foi renovado. Através da análise do giro é possível identificar estratégias para aumentar as vendas dos produtos, por exemplo, oferecendo promoções.

\subsection{QUADRO TEÓRICO}

O modelo proposto está baseado em três construtos teóricos conforme discutido na revisão da literatura (Quadro 5) que busca sistematizar essas principais práticas, as ferramentas de TI e o respectivo desempenho da organização em um ambiente enxuto.
a) Manufatura Enxuta (LM)
b) Tecnologia da informação (TI)
c) Desempenho Operacional (DO)

A partir desses construtos, torna-se possível discutir o alinhamento das práticas da manufatura enxuta com os recursos da tecnologia da informação, através da análise dos sistemas adotados pelas organizações (como, por exemplo: ERP, Kanban, sistemas interorganizacionais, workflow) e as respectivas contribuições deste ambiente informatizado aos objetivos da manufatura enxuta, sendo analisado através das medidas de desempenho (Figura 6). 
Quadro 5 - Quadro teórico

\begin{tabular}{|c|c|c|}
\hline Construto & Variáveis & Autores \\
\hline $\begin{array}{l}\text { Manufatura } \\
\text { Enxuta }\end{array}$ & $\begin{array}{l}\text { LM1 - Sistema Puxado - Kanban } \\
\text { LM2 - Melhoria contínua - Kaizen } \\
\text { LM3 - 5S } \\
\text { LM4 - Manutenção produtiva total - TPM } \\
\text { LM5 - Mapeamento do fluxo de valor } \\
\text { LM6 - Diminuição do tempo de setup } \\
\text { LM7 - Trabalho padronizado } \\
\text { LM8 - Heijunka }\end{array}$ & $\begin{array}{l}\text { Achanga et al. (2006); Bezerra (2008); Cottyn } \\
\text { et al. (2011); Dennis (2008); Chaves Filho } \\
\text { (2007); Galgano (2003); Hutchins (1998); } \\
\text { Jacob, Chase e Aquilano (2009); } \\
\text { Khanchanapong et al. (2014); Lian e Van } \\
\text { Landeghem (2007); Liker (2005); Martins e } \\
\text { Theóphilo (2009); Moyano-Fuentes e } \\
\text { Sacristán-Díaz (2012); Ohno (1997); Peças e } \\
\text { Henriques (2006); Powell, Riezebos e } \\
\text { Strandhagen (2012); Queiroz, Rentes e } \\
\text { Araujo (2009); Rasteiro (2009); Riezebos, } \\
\text { Klingenberg e Hicks (2009); Rother e Shook } \\
\text { (2003); Saia (2009); Sanches e Perez (2001); } \\
\text { Silva (2007); Slack, Chambers e Johnston } \\
\text { (2002); Stefanelli (2007); Sugai, McIntosh e } \\
\text { Novaski (2007); Womack, Jones e Roos } \\
\text { (1992); Womack e Jones (1996). }\end{array}$ \\
\hline $\begin{array}{l}\text { Tecnologia da } \\
\text { Informação }\end{array}$ & $\begin{array}{l}\text { TI1 - Utilização de ERP } \\
\text { TI2 - Utilização de MES } \\
\text { TI3 - Alinhamento Estratégico } \\
\text { TI4 - Sistemas Interorganizacionais } \\
\text { TI5 - Infraestrutura de TI }\end{array}$ & $\begin{array}{l}\text { Bell (2005); Bharadwaj (2000); Black (1998); } \\
\text { Chou e Tripuramallu (2005); Gonçalves e } \\
\text { Riccio (2009); Haberkamp et al. (2010); } \\
\text { Hartono et al. (2010); Henderson e } \\
\text { Venkatraman (1993); Hwang (2006); Laudon } \\
\text { e Laudon (2010); Mendes e Escrivão Filho } \\
\text { (2002); Meyer (2009); O'Brien (2002); } \\
\text { Powell e Strandhagen (2011); Saenz, Artiba e } \\
\text { Pellerin (2009); Sedano et al. (2011); Souza e } \\
\text { Zwicker (2001); Tallon (2010); Tallon e } \\
\text { Kraemer (2007); Wan e Chen (2007); Ward e } \\
\text { Zhou (2006); White (2006); Womack, Jones e } \\
\text { Roos (1992). }\end{array}$ \\
\hline $\begin{array}{l}\text { Desempenho } \\
\text { Operacional }\end{array}$ & $\begin{array}{l}\text { DO1 - Segurança } \\
\text { DO2 - Qualidade } \\
\text { DO3 - Entrega } \\
\text { DO4 - Custo } \\
\text { DO5 - Inventário }\end{array}$ & $\begin{array}{l}\text { Allio (2006); Bicheno (2004); Brosnahan } \\
\text { (2008); Dimancescu, Hines e Rich (1997); } \\
\text { Frigo (2003); Gaither e Frazier (2006); } \\
\text { Goldman (2005); Kaplan e Norton (1992, } \\
\text { 1993, 2005); Lawson, Stratton e Hatch } \\
\text { (2003); Liker e Meier (2006); Lovelock e } \\
\text { Wright (2006); Malone e Sinnett (2005); } \\
\text { Maltz, Shenhar e Reilly (2003); Marshall e } \\
\text { Heffes (2004); Maskell et al. (2011); Neely, } \\
\text { Gregory e Platts (2005); Neely (1999); } \\
\text { Rabaglio (2006); Sanjay (2008); Santos et al. } \\
\text { (2007); Shah e Ward (2003); Shepherd e } \\
\text { Günter (2006); Standard e Davis (2000); } \\
\text { Tangen (2005); Womack e Jones (1996); } \\
\text { Yeniyurt (2003). }\end{array}$ \\
\hline
\end{tabular}

Fonte: Elaborado pelo autor. 
Figura 6 - Framework do projeto de pesquisa Fonte: Autor.

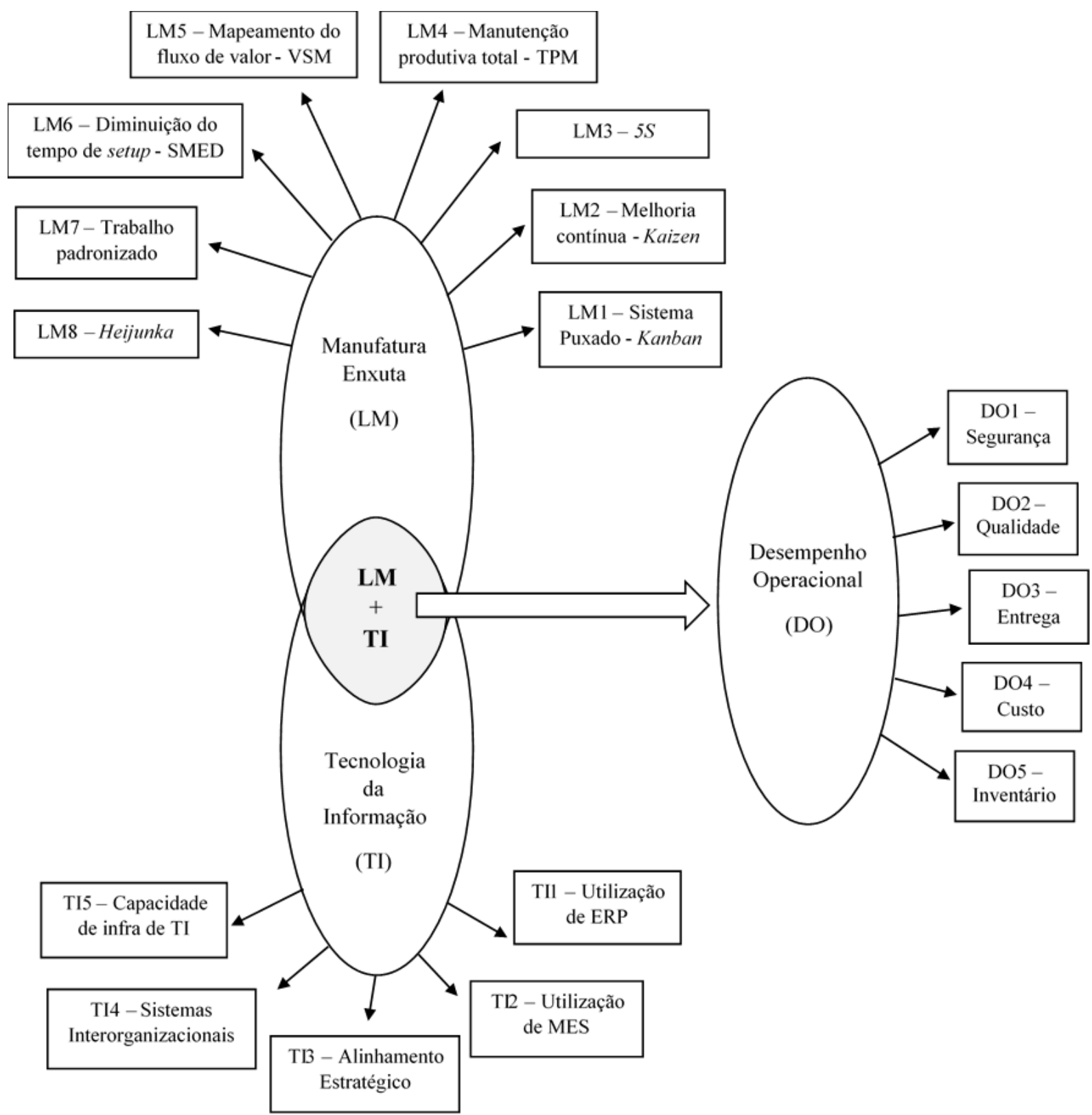




\section{METODOLOGIA}

O método adotado para o desenvolvimento desta pesquisa foi o estudo de caso. Segundo Yin (2010), o estudo de caso é apenas uma das várias maneiras de realizar a pesquisa de ciência social. Em geral, os estudos de caso são o método preferido quando: as questões "como" ou "por que" são propostas; o investigador tem pouco controle sobre os eventos; o enfoque está sobre um fenômeno contemporâneo no contexto da vida real. Adicionalmente, explora fenômenos contemporâneos dentro de um contexto da vida real e quando o controle que o investigador tem sobre os eventos é pouco ou nenhum (Yin, 2010).

De acordo com Yin (2010), a coleta de dados em um estudo de caso deve atender a três princípios:

a) Uso de múltiplas fontes de evidência, por exemplo, documentos, registros de arquivos, entrevistas, observação direta e participante. Tal princípio permite um processo de desenvolvimento de linhas convergentes de investigação, triangulação e corroboração dos fatos (Figura 7). Segundo Yin (2010), os problemas potenciais de validade do construto podem ser abordados com a triangulação, porque as múltiplas fontes de evidência proporcionam, essencialmente, várias avaliações do mesmo fenômeno.

Figura 7 - Convergência e não convergência de múltiplas fontes de evidências Fonte: Yin, 2010.

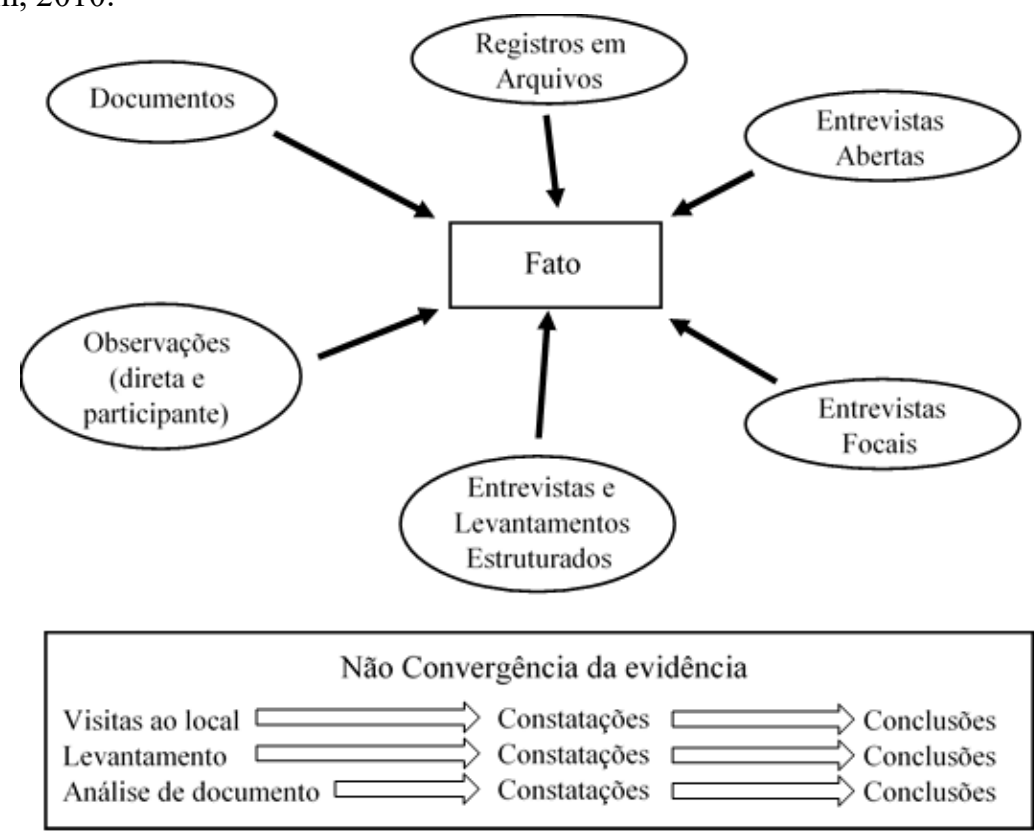


b) Criar uma base de dados do estudo incluindo notas, documentos, tabelas e narrativas.

c) Manter o encadeamento de evidências.

O Quadro 6, a seguir, apresenta os pontos fortes e fracos de algumas fontes de evidência que serão usadas nesta pesquisa:

Quadro 6 - Pontos fortes e fracos de fontes de evidências

\begin{tabular}{|c|c|c|}
\hline Fontes de evidência & Pontos fortes & Pontos fracos \\
\hline $\begin{array}{l}\text { Documentação - documentação de } \\
\text { produção, relatórios gerenciais, } \\
\text { materiais de apresentações feitas } \\
\text { ao longo do projeto de } \\
\text { implantação, outros. }\end{array}$ & $\begin{array}{l}\text { Estável }- \text { pode ser revista } \\
\text { repetidamente } \\
\text { Discreta - não foi criada em } \\
\text { consequência do estudo de caso } \\
\text { Exata - contém nomes, referências } \\
\text { e detalhes exatos de um evento } \\
\text { Ampla cobertura - longo período } \\
\text { de tempo, muitos eventos e muitos } \\
\text { ambientes }\end{array}$ & $\begin{array}{l}\text { Recuperabilidade - pode ser difícil } \\
\text { de encontrar } \\
\text { Seletividade parcial, se a coleção } \\
\text { for incompleta } \\
\text { Parcialidade do relatório - reflete } \\
\text { parcialidade (desconhecida) do } \\
\text { autor } \\
\text { Acesso - pode ser negado } \\
\text { deliberadamente }\end{array}$ \\
\hline $\begin{array}{l}\text { o- acesso dos } \\
\text { ho período de } \\
\text { li de } 2016\end{array}$ & $\begin{array}{l}\text { [Idem à documentação] } \\
\begin{array}{l}\text { Precisos e geralmente } \\
\text { quantitativos }\end{array}\end{array}$ & $\begin{array}{l}\text { [Idem à documentação] } \\
\text { Acessibilidade devido a razões de } \\
\text { Privacidade }\end{array}$ \\
\hline $\begin{array}{l}\text { Entrevistas - foco na visão dos } \\
\text { gestores e funcionários. }\end{array}$ & $\begin{array}{l}\text { Direcionadas - focam diretamente } \\
\text { os tópicos do estudo de caso } \\
\text { Perceptíveis - fornecem } \\
\text { inferências e explanações causais } \\
\text { percebidas }\end{array}$ & $\begin{array}{l}\text { Parcialidade devido às questões } \\
\text { mal-articuladas } \\
\text { Parcialidade da resposta } \\
\text { Incorreções devido à falta de } \\
\text { memória } \\
\text { Reflexividade - o entrevistado dá } \\
\text { ao entrevistador o que ele quer } \\
\text { ouvir }\end{array}$ \\
\hline $\begin{array}{l}\text { Observações diretas - realizadas } \\
\text { pelo pesquisador desde o ano de } \\
\text { 2014, quando passou a integrar o } \\
\text { time mundial. }\end{array}$ & $\begin{array}{l}\text { Realidade - cobre eventos em } \\
\text { tempo real } \\
\text { Contextual - cobre o contexto do } \\
\text { "caso" }\end{array}$ & $\begin{array}{l}\text { Consome tempo } \\
\text { Seletividade - ampla cobertura é } \\
\text { difícil sem uma equipe de } \\
\text { observadores } \\
\text { Reflexividade - evento pode } \\
\text { prosseguir diferentemente porque } \\
\text { está sendo observado } \\
\text { Custo - horas necessárias pelos } \\
\text { observadores humanos }\end{array}$ \\
\hline $\begin{array}{l}\text { Observação participante - } \\
\text { realizada pelo pesquisador desde o } \\
\text { ano de 2014, quando passou a } \\
\text { integrar o time mundial. }\end{array}$ & $\begin{array}{l}\text { [Idem aos acima para observações } \\
\text { diretas] } \\
\text { Discernível ao comportamento e } \\
\text { aos motivos interpessoais }\end{array}$ & $\begin{array}{l}\text { [Idem aos acima para as } \\
\text { observações diretas] } \\
\text { Parcialidade devido à manipulação } \\
\text { dos eventos pelo observador } \\
\text { participante }\end{array}$ \\
\hline
\end{tabular}

Fonte: Adaptado de Yin, 2010.

\subsection{PROTOCOLO DE PESQUISA}

O protocolo, conforme se vê no Quadro 7, é um instrumento orientador e regulador da condução da estratégia de pesquisa (YIN, 2010; MARTINS; THEÓPHILO, 2009). 
Quadro 7 - Protocolo de pesquisa

a) Visão Geral do projeto de estudo de caso

- Objetivos

- Justificativas

- Antecedentes do tema

- Revisão bibliográfica

b) Procedimentos de Campo

- Pessoas de contato para entrevistas

- Relatos de observação

- Plano de coleta de dados

c) Questões do Estudo

- Proposta de questões para direcionar a entrevista:

- Identificação do entrevistado (Nome / Área / Relação com o sistema global/desde quando)

- As questões estão em desenvolvimento

d) Guia para o Relatório do Estudo

- Apresentação da empresa

- Dados e documentos coletados

- Análises do caso à luz do que foi visto na revisão bibliográfica

Fonte: Produzido pelo autor.

\subsection{ESCOLHA DAS EMPRESAS}

Para o desenvolvimento da pesquisa foram escolhidas duas plantas. As empresas encontram-se em processo de implantação da manufatura enxuta, mas vale ressaltar que em diferentes níveis de implementação, os quais serão avaliados através da ferramenta apresentada no Apêndice A. Cada planta também já possui um conjunto de ferramentas de TI para apoio à gestão. A justificativa para efetuar um estudo em diferentes plantas deve-se à possibilidade de capturar especificidades culturais e tecnológicas que podem contribuir para a análise e gerar contribuições práticas e teóricas ao problema de pesquisa. O estudo multicasco será realizado em empresas que fornecem ao mercado soluções e produtos como itens arquitetônicos e equipamentos de pulverização necessários ao acabamento ou proteção. Por questões de sigilo, as empresas serão identificadas com um nome fictício.

\subsection{PERFIL DOS ENTREVISTADOS}


Os dados primários serão coletados por meio da observação direta, análise de arquivos fornecidos pela organização e entrevistas semiestruturadas. Os entrevistados nas empresas serão gerentes industriais, supervisores de fábrica, líderes de produção e responsáveis pela tecnologia da informação de cada unidade. Deste modo será obtida uma variedade de informações, proporcionando uma discussão ampla na triangulação com os fundamentos lógicos entre as evidências, moldando o conteúdo conforme orientações de Yin (2010). Veja na Tabela 1 o nível hierárquico dos entrevistados.

Tabela 1 - Perfil dos entrevistados

\begin{tabular}{c|c|c}
\hline Nível Hierárquico & Empresa A & Empresa B \\
\hline Gerente Industrial & 1 & 1 \\
\hline Gestor TI & 1 & 1 \\
\hline Supervisor / Líderes & 2 & 3 \\
\hline Qualidade & 1 & 1 \\
\hline
\end{tabular}

Fonte: Autor.

\subsection{PROPOSIÇÕES DE PESQUISA}

Segundo Martins e Theóphilo (2009), somente a questão de pesquisa não aponta a direção correta do que se deve estudar e, dessa maneira, as proposições se mostram importantes por serem teses expostas para serem demonstradas e defendidas.

Para o desenvolvimento deste estudo, formulou-se as seguintes proposições de pesquisa:

a) Proposição 1. As empresas precisam compreender o relacionamento da tecnologia de informação e as práticas da manufatura enxuta com o propósito de melhorar o desempenho operacional das empresas (KHANCHANAPONG et al., 2014).

b) Proposição 2. A manufatura enxuta e os sistemas ERP são considerados duas das estratégias utilizadas em empresas com objetivo de melhorar seu desempenho, mas se observa paradoxo entre os sistemas ERP e da manufatura enxuta (POWELL; STRANDHAGEN, 2011).

c) Proposição 3. Apesar das soluções de BI enfatizarem sua aplicação em análises dos tipos estratégicas e táticas, que são mais voltadas ao médio e longo prazo, 
com a difusão dos sistemas de informações nas organizações, o BI pode ser também do tipo operacional e voltado para análises das atividades diárias e apoiar a implementação da manufatura enxuta (WHITE, 2006).

\subsection{ESTUDOS DE CASO}

Seguem os dados referente aos estudos de casos realizados:

\subsubsection{Caso A}

Atualmente é composta por mais de 170 empresas com 16.500 funcionários. É líder mundial em decoração de janelas e produtos arquitetônicos. Seus produtos são forros, fachadas, cortinas, persianas e toldos, sendo as cortinas e persianas o seu carro chefe.

$\mathrm{Na}$ América Latina possui fabricas na Argentina, Brasil, Chile, Colômbia, México, Panamá, Peru, Uruguai e Venezuela. É uma empresa de capital aberto. O faturamento anual do grupo é de 3,7 bilhões de dólares. A empresa vem crescendo nos últimos anos e está reduzindo seus custos.

A unidade Brasil é uma montadora de persianas, toldos e cortinas e fornece apenas para o mercado local através de revendedores. A empresa tem uma fábrica em Campinas (SP) que opera desde 1991. Hoje no Brasil tem 300 funcionários, sendo 150 na área produtiva. São 14 linhas de produção no total, sendo que a linha piloto de implementação da manufatura enxuta é a de o maior volume de produção. Estão planejando mais 2 anos para a implementação total.

No Brasil, 75\% dos fornecedores de matéria-prima são as outras fabricas do grupo localizadas na Ásia, China, Europa e América Latina. Como exemplo, podemos citar a fábrica do Chile, que fornece os trilhos e perfis de alumínio, e a matriz na Holanda, que fornece os tecidos. A unidade do Brasil não fornece matéria-prima para as outras unidades.

\subsubsection{Manufatura Enxuta}

A ideia de implementação da manufatura enxuta surgiu em 2006, mas somente em setembro de 2013 iniciaram um projeto piloto na linha do produto "Roler", num conceito de operação em fluxo contínuo, controlando o refugo e a produtividade visualmente; até então, a empresa não possuía uma cultura de gestão visual. Durante esse período, entre a necessidade 
de implementação e o início da linha piloto, a empresa não possuía pessoas dedicadas à manufatura enxuta.

Sua capacidade atual de produção é de 1.500 peças/dia, mas atualmente está produzindo 750 peças/dia devido à crise na economia.

Ferramentas da manufatura enxuta:

a) Sistema puxado - sim, foi o foco na implementação da manufatura enxuta.

b) Melhoria contínua Kaizen - sim, mas não é uma cultura, não está implementada em toda a organização.

c) $\mathbf{5 S}$ - iniciou com o treinamento de multiplicadores lean, porém, com a saída desses funcionários devido a vários fatores (crise, greve, motivos particulares), foi reduzindo o enfoque no $5 \mathrm{~S}$ no geral. Hoje o foco é na linha piloto.

d) TPM - não. A empresa possui uma cultura de manutenção dos maquinários, mas não há registros e um controle definido.

e) Mapeamento de fluxo de valor - atualmente, os problemas são muito visíveis, não sendo necessário o levantamento do fluxo de valor. Apenas executam seminários juntamente com o Instituto Lean Brasil, nos quais os participantes fazem o levantamento dando sugestões de melhoria através do fluxo de valor. Detectaram que o principal problema é o alto volume de estoque para atendimento rápido a seus clientes. Esse giro de estoque é normal nas empresas do grupo.

f) Setup rápido - possuem pouco maquinário. $\mathrm{O}$ tempo de preparação das máquinas varia em torno de uma hora e meia. Iniciaram recentemente a implementação do conceito do setup rápido nas linhas piloto.

g) Trabalho padronizado - sim. Há um ano tem um funcionário na engenharia focado na elaboração do documento. Todas as linhas piloto possuem um detalhamento da operação de todas as atividades.

h) Heijunka - tem um piloto no PCP. A fábrica somente produz sob demanda, não produz para estoque. Hoje, com a baixa demanda, todos os pedidos que entram no dia vão para a linha e são atendidos no mesmo dia.

Para verificar o grau de implementação e enxugamento da empresa utilizamos a norma SAE J4000 e obtivemos os seguintes resultados: 
Tabela 2 - Análise conforme norma SAE J4000 para empresa A

\begin{tabular}{c|l|c|c}
\hline $\begin{array}{c}\text { Elemento da } \\
\text { norma SAE } \\
\text { J4000 }\end{array}$ & \multicolumn{1}{|c|}{ Tema Principal } & $\begin{array}{c}\text { Grau de } \\
\text { Implementação }\end{array}$ & $\begin{array}{c}\text { Grau de } \\
\text { Enxugamento }\end{array}$ \\
\cline { 1 - 2 } Elemento 4 & Gerência e confiabilidade & $37 \%$ & \\
\cline { 1 - 2 } Elemento 5 & Pessoas e RH & $41 \%$ & \multirow{2}{*}{$39 \%$} \\
\cline { 1 - 2 } Elemento 6 & Sistema de Informação & $55 \%$ & \\
\cline { 1 - 2 } Elemento 7 & Relação Cliente/Fornecedor e Organização & $8 \%$ & \\
\hline Elemento 8 & Produto e Gestão de Produto & $54 \%$ & \\
\hline Elemento 9 & Produto e Fluxo de Processos & $54 \%$ & \\
\hline
\end{tabular}

Fonte: Elaborado pelo autor.

\subsubsection{Tecnologia da Informação}

O investimento em TI é limitado em 1,5\% do faturamento. No ano passado houve o maior investimento em TI, que representou $0,8 \%$ de seu faturamento. O gestor de TI é também responsável por operações na América Latina. Possui duas equipes separadas, 5 funcionários dando suporte para a unidade Brasil e outra equipe para suporte a América Latina, com mais 6 pessoas. Todos os funcionários são capacitados com formação na área.

A TI atua em todas as áreas da empresa, estando alinhada à visão estratégica da empresa. O investimento em TI é prioridade na empresa, pois estão iniciando um processo de integração das fabricas da América Latina.

Estão mudando o ERP atual, o Protheus da TOTVS, que é uma linha de software integrado (ERP/CRM/HCM/SCM), para o sistema Microsoft Dynamics, que consideram um produto completo, pois abrange as áreas de planejamento financeiro, administração financeira, produção industrial, controle de estoques, projetos e contabilidade. O prazo para implementação completa é de um ano. Atualmente, as unidades na Europa utilizam o SAP.

O usuário sempre está presente no desenvolvimento de TI. Existe um comitê de aprovação para os projetos de TI formado por gestor, equipe de TI e usuário. Após aprovado o desenvolvimento tem-se o cuidado de não automatizar o desperdício. Para a aprovação existe uma priorização dos projetos considerando-se o tempo para a execução, a redução estimada do custo e o impacto para o negócio.

O gestor de TI menciona que:

Os funcionários dizem que a TI auxilia muito no processo da empresa, mas em alguns setores há o sentimento que é necessário um detalhamento muito grande do problema para a TI aprovar um projeto de melhoria. 
Existe um sistema para a cadeia de suprimentos implementado com seus fornecedores mundiais. O relacionamento com a revenda de produtos é feito através de um sistema que garante até $99 \%$ da colocação dos pedidos pelos próprios revendedores. Esse sistema fideliza o revendedor, o que possibilitou diminuir drasticamente os erros de entrada de pedidos, uma vez que existe milhares de combinações possíveis do produto. Dessa forma, a empresa acabou por reduzir o número de funcionários no atendimento ao cliente.

O processo na produção é muito manual e, no Brasil, o custo para automatização da linha é muito elevado, sendo assim a empresa se dedica em otimizar o processo e implementar pequenos projetos de TI para auxiliar o processo produtivo. Como exemplo tem-se o sistema de apontamento das operações através de coletores por código de barras.

A prioridades de investimento de TI são as seguintes:

a) Hardware: tem investimento, mas não é o ponto forte, pois já possui uma boa estrutura instalada.

b) Software: grande parte do investimento atual em TI é em software, já que estão migrando do ERP Protheus da TOTVS para o Dynamics da Microsoft.

c) Manutenção da TI: existe o investimento para manter os equipamentos dos usuários atualizados. Espera-se que nos próximos 2 anos o investimento em TI seja maior do que nos anos anteriores.

É possível dizer que a estratégia de negócio da empresa está focada na infraestrutura e nos processos organizacionais e produtivos e que a infraestrutura e o processo de tecnologia da informação estão alinhados, auxiliando no alcance de seus objetivos.

\subsubsection{Relacionamento da manufatura enxuta e da TI}

O gestor de TI afirma que:

No nosso ponto de vista, a TI auxilia muito a implementação da manufatura enxuta.

A gestão de operações e de TI de cada fábrica da América Latina possui uma equipe local que se reporta ao gestor brasileiro na questão de implementação da manufatura enxuta e tecnologia da informação. Isto se deve ao pioneirismo e aos bons resultados obtidos pela 
fábrica brasileira na implementação das técnicas da manufatura enxuta e da tecnologia da informação.

O responsável pela implementação da manufatura enxuta aponta que:

Normalmente não se automatiza inicialmente um projeto para não se automatizar o desperdício. Executa-se o projeto manualmente para se identificar os desperdícios e fixar os conceitos, sendo o próximo passo o uso da TI, que vem para simplificar o novo processo.

Dentre os projetos da tecnologia de informação implementados no chão de fábrica que auxiliam a manufatura enxutada podemos citar: a introdução de coletores de informação nas linhas de produção, o uso de computadores pelos líderes de células na obtenção de informações gerenciais em tempo real, o novo apontamento do kanban e monitores com indicadores de tempo tak e produtividade nas linhas que determinam o ritmo de produção. Esses produtos foram desenvolvidos pelo time de TI local.

Um dos planos é a criação de uma base de conhecimento entre as empresas da América Latina sobre os projetos de implementação da manufatura enxuta. Ela servirá de base para futuras implementações de estudo para os formadores de opinião para o treinamento do pessoal envolvido no processo.

\subsubsection{Indicadores de desempenho operacional}

Segurança - existe o indicador na área do SESMET (Serviço Especializado em Engenharia de Segurança e em Medicina do Trabalho). Na manufatura enxuta existe a preocupação com os aspectos ergonômicos nas células de produção durante a implementação do fluxo contínuo. O pessoal da CIPA (Comissão Interna de Prevenção de Acidentes), responsável pela ginástica laboral, auxilia também na detecção de condições inseguras relatadas pelos funcionários. Existe ainda uma pequena abertura na reunião introdutória diária de 5 minutos para falar dos aspectos de segurança, sendo que o foco principal dessa reunião são as prioridades e o desempenho do dia anterior.

Qualidade - existe uma área de suporte técnico que, através da revenda, levanta e auxilia nos problemas com o cliente final. Caso ocorra um defeito no produto, a revenda vai até o cliente para constatar o problema e verificar se está na garantia. O produto defeituoso é encaminhado de volta à fábrica para o conserto. Há percepção de que houve uma melhoria na 
qualidade dos produtos após a implementação da manufatura enxuta, devido a redução do número de chamadas das reclamações dos clientes no pós-venda (aproximadamente 35\%). Entretanto, não há registros sobre a classificação dos problemas.

Entrega - houve uma melhora considerável após a implementação da manufatura enxuta referente à entrega dos produtos. No que diz respeito ao prazo de entrega, de 5 dias úteis, antes da implementação da manufatura enxuta a taxa de atendimento desse prazo era de 80 a 85\%, após a implementação é de 95 a 99\%. Na questão de priorização de peças na linha de produção houve uma grande melhora. Antes do fluxo contínuo era constante a reclamação e existia certa dificuldade em se localizar em que fase do processo produtivo estava a peça encomendada. Frequentemente não se encontrava a peça e se executava uma nova ordem de produção para atender a necessidade de forma prioritária. Em algum momento a peça aparecia, provocando uma duplicidade de produto, gerando a necessidade de desmontar e retornar as partes do produto para o inventário. Com a implementação do fluxo contínuo não há mais a ocorrência destes casos de duplicidade de produção. Outra questão é o lead time da linha piloto, que era de 2 a 2,5 dias e, após implementação do fluxo contínuo, está entre 25 a 30 minutos.

Custo - houve redução da mão de obra na implementação da manufatura enxuta, reduzindo o tempo de produção do produto, mas a mão de obra não é tão relevante no custeio do produto que é baseado nos elevados custos da matéria-prima.

Inventário - há um elevado nível de inventário para atender as necessidades do cliente. É muito difícil prever a tendência do mercado arquitetônico. Já tentaram reunir arquitetos para verificar essa tendência, mas o mercado é quem dita as regras.

Após a implementação da manufatura enxuta houve uma grande redução do inventário em processo. Antes, a transferência da matéria-prima para processo era feita através de bloco de produção, isto é, rodava-se o sistema com as necessidades de um determinado período (em torno de 1.500 peças/dia) e automaticamente era transferido na sua totalidade o material necessário para a linha de produção, sendo que a mesma não tinha a capacidade para a execução do lote de produção (produção diária de 600 a 700 peças/dia). Isto ocasionava um acumulo de ordens na linha de produção. Com a implementação da manufatura enxuta a produção está sendo feita no ritmo da demanda do cliente, evitando o acumulo de material na linha.

$\mathbf{5 S}$ - Inicialmente, na implementação era feita uma auditoria dos $5 \mathrm{~S}$, mas, devido à mudança de foco e no quadro de pessoal, essa atividade parou de ser executada. Existe um plano para o seu retorno em breve. 


\subsubsection{Caso B}

Encontrar soluções inovadoras de atomização de tinta para alcançar um melhor acabamento no produto final de seus clientes tem sido a filosofia da empresa por mais de 120 anos. Hoje a empresa tornou-se a principal fornecedora de equipamentos de pintura/acabamento por pulverização do mundo, atuando no setor industrial nos segmentos aeroespacial, madeira, plástico, metal, dente outros, e nos mercados automotivo original e de repintura. Os operadores de seu produto vão desde o pintor profissional até o amador.

A empresa possui fábricas, centros de desenvolvimentos e escritórios comerciais nos Estados Unidos, Inglaterra, Alemanha, Suíça, França, Austrália, China, Japão, Índia, Brasil e México. O faturamento anual do grupo de que faz parte é de 3,5 bilhões de dólares, sendo que o segmento de tecnologia de acabamento representa 264 milhões de dólares. A empresa vem crescendo nos últimos anos, reduzindo seus custos e verticalizando o processo de fabricação.

Ela está instalada no Brasil desde 1954, atualmente possui uma fábrica na cidade de São Paulo com 50 funcionários, sendo 27 na área produtiva. Nesta unidade, manufatura pistolas de pintura, filtros reguladores de pressão, tanques de pintura e equipamentos de pintura eletrostática a pó. A unidade Brasil importa $20 \%$ dos produtos comercializados no país de outras unidades do grupo e exporta para Inglaterra, Estados Unidos, Austrália e Japão.

\subsubsection{Manufatura Enxuta}

A implementação da manufatura enxuta foi iniciada em 2012 com a mudança da gerência industrial, através da implantação de algumas ferramentas de gestão enxuta na fábrica, apesar de haver indícios de utilização de algumas ferramentas da qualidade desde o ano de 2001. No início de 2015 as empresas foram adquiridas por um grupo que tem como filosofia a manufatura enxuta, buscando a melhoria contínua dos processos e a verticalização dos processos produtivos.

Sua capacidade atual de produção é de 4.000 pistolas/mês, mas, atualmente, está produzindo 3.200 pistolas/mês devido à crise na economia do país.

Ferramentas da manufatura enxuta:

a) Sistema puxado - sim. Há 20 anos a empresa iniciou os primeiros passos para a implementação dos cartões de kanban para itens produzidos internamente, 
puxando o processo produtivo. Esse processo trabalhava juntamente, e às vezes em conflito, com a cultura existente de uma gestão por demanda através de cálculos baseados nas necessidades dos últimos 6 meses. Em 2012 foi implementado um módulo de gestão do estoque do sistema ERP que a empresa possui. Esse modulo auxiliou no cálculo e na revisão periódica das quantidades de produtos nas etiquetas Kanban (para itens comprados e montados internamente) e Heijumka (para itens usinados internamente). Por meio das informações de demanda passadas para cada item e de modelos matemáticos desenvolvidos e testados que foram implantados nos campos disponíveis da gestão do estoque foram elaborados relatórios para emissão das etiquetas Kanban e Heijumka. Esse processo automatizou horas de análise e cálculos em planilhas eletrônicas, simplificando e aumentando a frequência das revisões dos cálculos das etiquetas que passaram de seis para dois meses. Nota-se, através dos indicadores de inventário e entrega, uma redução do estoque em mãos e do prazo de entrega, respectivamente, após a implementação.

b) Melhoria contínua Kaizen - sim. Desde o início de 2015 a empresa possui dois tipos de eventos. O primeiro são as reuniões diárias de 10 minutos realizadas em todas as áreas produtivas, nas quais são analisados os indicadores de desempenho da área, sendo levantados os problemas referentes ao não cumprimento das metas, bem como são propostas sugestões de melhorias para sua implementação e a definição do responsável e dos prazos. O segundo são eventos Kaizen, realizados a cada dois meses com duração de uma semana, em áreas específicas contando com a participação de áreas cliente/fornecedor. Durante o evento são ministrados treinamentos aos participantes e, em seguida, são coletados dados na área em que são discutidas as sugestões de melhoria e suas implementações voltadas para um aumento de produtividade, redução de custos, redução de inventário, redução de espaço e melhorias na segurança.

c) $\mathbf{5 S}$ - Nos últimos 3 anos houve dois treinamentos de $5 \mathrm{~S}$ para todos os funcionários da empresa. Foi implementado um modelo de 5S progressivo, a empresa foi dividida em 7 zonas, os funcionários foram treinados como auditores e, semanalmente, num regime de rodízio, executam uma verificação de cada zona em que se observam possíveis melhorias referentes a utilização de máquinas e equipamentos, organização, limpeza e implementação de uma cultura dos $5 \mathrm{~S}$. 
d) TPM - parcialmente. Existe uma catalogação de máquinas e equipamentos, bem como uma classificação (equipamentos críticos, importantes ou padrão). Cada máquina possui um plano de manutenção preventiva. Estão trabalhando num sistema de controle de horas em manutenção corretiva e num calendário de manutenção preventiva.

e) Mapeamento de fluxo de valor - Há um ano realizaram um evento onde os funcionários-chave foram treinados e elaboraram seu primeiro mapeamento de fluxo de valor, que serviu para determinar os eventos Kaizen de melhoria bimestrais.

f) Setup rápido - Houve um evento na área de usinagem há 5 meses dedicado a iniciar trabalhos referentes ao setup rápido com a confecção de trabalho padronizado e os gabaritos. Houve uma melhora de 2 horas de setup para 40 minutos.

g) Trabalho padronizado - sim. Iniciaram recentemente a execução da folha do trabalho padronizado para cada produto fabricado internamente; atualmente $30 \%$ das peças possuem a folha.

h) Heijunka - há um piloto bem-sucedido em uma das áreas da usinagem e estão em fase de expansão do modelo para outras áreas.

Para verificar o grau de implementação e enxugamento da empresa utilizamos a norma SAE J4000 e obtivemos os seguintes resultados:

Tabela 3 - Análise conforme norma SAE J4000 para empresa B

\begin{tabular}{c|l|c|c}
\hline $\begin{array}{c}\text { Elemento da } \\
\text { norma SAE } \\
\text { J4000 }\end{array}$ & \multicolumn{1}{|c|}{ Tema Principal } & $\begin{array}{c}\text { Grau de } \\
\text { Implementação }\end{array}$ & $\begin{array}{c}\text { Grau de } \\
\text { Enxugamento }\end{array}$ \\
\cline { 1 - 2 } Elemento 4 & Gerência e confiabilidade & $66 \%$ & \\
\hline Elemento 5 & Pessoas e RH & $66 \%$ & \multirow{2}{*}{$46 \%$} \\
\hline Elemento 6 & Sistema de Informação & $36 \%$ & \\
\hline Elemento 7 & Relação Cliente/Fornecedor e Organização & $25 \%$ & \\
\hline Elemento 8 & Produto e Gestão de Produto & $22 \%$ & \\
\hline Elemento 9 & Produto e Fluxo de Processos & $33 \%$ & \\
\hline
\end{tabular}

Fonte: Elaborado pelo autor.

\subsubsection{Tecnologia da Informação}

O investimento em TI é limitado em $0,5 \%$ do faturamento. A gestão da TI está ligada à área financeira da empresa. Possui somente uma pessoa na área de TI para dar suporte aos 
usuários principalmente no hardware e manutenção do software ERP, conta com os serviços de consultoria do provedor do software ERP e, quando necessário, contrata mão de obra temporária para realizar pequenos projetos. O responsável pela TI está na empresa há 40 anos e foi uma das pessoas que introduziu a informática na empresa na década de 80 .

A TI atua em todas as áreas da empresa e, desde 2001, possui um sistema ERP integrado, o Omega da ABC71. Na implementação do sistema houve a participação de todas as áreas da empresa e todos os usuários foram treinados e periodicamente se atualizam. Além do ERP, a empresa possui o Sadig Análises, que integra e consolida dados de seu sistema ERP, gerando e distribuindo informações para uma gestão mais efetiva dos negócios, indicando as melhores alternativas e melhorando os resultados empresariais.

O gestor de TI menciona que:

Alguns usuários se tornaram especialistas em certas ferramentas. Por exemplo, na área produtiva existe a necessidade de elaboração de relatórios para o controle e acompanhamento da produção, então um funcionário se tornou especialista na ferramenta do ERP que estrai as informações do banco de dados e gera relatórios.

Outro usuário da área financeira utiliza as informações extraídas do banco de dados e as manipula em tabela dinâmicas do Excel da Microsoft. Quando necessário esses funcionários auxiliam outros usuários em outras áreas.

Como a empresa possui menos de 50 funcionários foi notado uma grande integração entre as áreas, o que facilita o levantamento e a implementação de melhorias, sendo que os quatro gestores de área (financeira, vendas e marketing, produtiva e geral) participam ativamente dessas atividades.

O processo na produção no Brasil está dividido em dois extremos, predominantemente manual na linha de montagem dos equipamentos e automatizado na área de usinagem de peças. Desse modo, a empresa se dedica a otimizar o processo e implementar pequenos projetos de TI para auxiliar o processo produtivo.

O gestor industrial afirma que:

A TI nos auxilia na análise das informações em tempo real, evitando a inconsistência dos dados. Ela é uma ferramenta que auxilia a implementação da manufatura enxuta.

Prioridade de investimento de TI: 
a) Hardware: tem investimento para manter e atualizar sua plataforma instalada.

b) Software: grande parte do investimento é utilizada para manter o sistema ERP Omega da ABC71.

c) Manutenção da TI: existe o investimento para manter os equipamentos dos usuários atualizados.

No que se refere à estratégia de negócios da empresa é possível dizer que está alinhada com a infraestrutura e os processos organizacionais e produtivos, sendo que a infraestrutura e processo de tecnologia da informação são utilizados como suporte e focados no cumprimento de processos e atividades legais.

\subsubsection{Relacionamento da manufatura enxuta e da TI}

O responsável pela TI aponta que:

Para nós, a manufatura enxuta veio auxiliar na implementação de nosso ERP na fábrica. Ele está sendo utilizado para atualizar os indicadores diários de produção.

O responsável pela TI é também o responsável pela área fiscal e financeira da empresa. Ele menciona que houve um grande auxilio da área produtiva na implementação do novo módulo industrial que é fundamental para a elaboração do bloco K. Esse novo módulo auxilia na manutenção e unificação da informação em uma única base de dados referente às ordens de produção com o detalhamento de horas e consumos produtivos.

O responsável pela implementação da manufatura enxuta relata que:

A tecnologia da informação está sendo utilizada como uma ferramenta de análise e extração de informações dos dados produtivos que serve para validar as melhorias que estão sendo implementadas com o avanço da manufatura enxuta.

Dentre os projetos da tecnologia de informação implementados no chão de fábrica que apoiam a manufatura enxuta podemos citar: os relatórios desenvolvidos com os indicadores diários em cada setor, o uso de computadores pelos líderes de células na obtenção de informações gerenciais em tempo real, o novo apontamento de ordem de serviço e 
procedimento de faturamento. Esses produtos foram desenvolvidos pelos consultores do ERP e pelo pessoal da área produtiva.

O processo de entrada de pedidos e faturamento foi modificado. Ao entrar com um pedido do cliente no sistema ERP, ele fica disponível para a área de produção, que a cada duas horas emite etiquetas para cada item do pedido. As informações contidas nessas etiquetas são número do pedido, item do pedido, identificação do produto, quantidade, cliente, prazo de entrega e endereçamento do produto. As etiquetas puxam a produção, retirando o produto dos supermercados que existem nas áreas produtivas, ou iniciam a fabricação puxada do item. pós a separação ou finalização do processo produtivo os produtos são embalados, identificados com as etiquetas e encaminhados ao setor de expedição. Ao entrar nessa área é informado ao sistema que a mercadoria está pronta através da leitura dos códigos de barra existentes na etiqueta. Essas informações ficam disponíveis no sistema para as áreas produtivas, que verificam os itens pendentes para se completar o pedido do cliente, expedição, para emissão do romaneio de embarque quando o pedido está completo, supervisão de fábrica, que as utiliza para tomada de decisões (emissão parcial do pedido ou priorização do processo produtivo), e vendas, que informa ao cliente a posição de seu pedido. Em tempo real, essas informações são obtidas através de relatórios customizados que são impressos ou visualizados nos monitores dos colaboradores. As reuniões diárias, no início do turno, utilizam-nas para priorizar atividades e encontrar medidas para melhoria do processo produtivo.

Outro projeto é a utilização do modulo de gestão do estoque que foi parametrizado para auxiliar na revisão e determinação das quantidades de peças do kanban de produção. Além disso, o ERP possui um módulo de controle dos ativos que auxilia na gestão do TPM.

\subsubsection{Indicadores de desempenho operacional}

Na empresa são realizadas reuniões diárias de 15 minutos em quatro áreas para avaliação dos indicadores de desempenho pelos funcionários e a pesquisa de melhorias com a finalidade de atingir as metas pré-fixadas.

Segurança - Possui dois indicadores, a "cruz de segurança", para o acompanhamento de dias sem acidentes em cada área produtiva, e a taxa de incidentes mensal, que é um cálculo matemático que permite comparar com qualquer empresa que relate seus incidentes a partir de uma mesma base. Esse cálculo se baseia numa taxa de 200 mil horas de trabalho, o que equivale a uma empresa com 100 funcionários que trabalham 40 horas por semana durante 50 semanas do ano. O objetivo atual é uma taxa menor que 2,9, sendo que a empresa está com 
taxa 0 . Este resultado se deve à comissão interna de prevenção de acidentes que é atuante e à realização de reuniões diárias em cada área, nas quais são levantados os atos e as condições inseguras de trabalho, bem como ações preventivas.

Qualidade - Em cada área existem indicadores em partes por milhão (ppm) de refugo ou reclamações de clientes. No caso de reclamação por parte do cliente externo o índice está em $76 \mathrm{ppm}$, sendo que o objetivo é ser menor que $250 \mathrm{ppm}$. Isto se deve ao teste final de $100 \%$ de todos os equipamentos produzidos pela empresa. Existem áreas, como o setor usinagem, onde estão sendo executados diversos eventos kaizen para melhoria, que já estão reportando resultados: o índice de refugo, em 2015, era de 32.000 ppm e, em 2016, é de $22.000 \mathrm{ppm}$.

Entrega - Houve uma melhora considerável após a implementação da manufatura enxuta em referência à entrega dos produtos. O prazo de entrega, há 5 anos, era de 30 a 45 dias; agora, em 2016, o prazo médio está em 3 dias, sendo que o índice de pedidos entregues no prazo está em 97\%. Isto se deve a uma verticalização e ao levantamento do fluxo de valor de seus produtos no último ano, que possibilitou a montagem de um calendário de eventos kaizen para melhoria do processo produtivo, como o quadro heijunka, o formulário hora $\mathrm{x}$ hora, preparação rápida e introdução do programa de manutenção produtiva total. Atualmente, observa-se um fluxo contínuo no setor de montagem com redução da área física, algo totalmente diferente do que havia há dois anos, quando se observava produtos semimontados aguardando a chegada de peças para a finalização. Antes do fluxo contínuo era constante as reclamações e existia uma certa dificuldade em se obter informações referentes ao prazo no processo produtivo.

Custo - A empresa utiliza o índice de produtividade como sendo o faturamento por funcionário por dia. Tem como objetivo um crescimento de $15 \%$ em relação ao último período. Neste último ano, com a implementação da manufatura enxuta, houve diversas melhorias no processo de fabricação que resultou numa redução dos 32 funcionários para 27 na área produtiva. Os funcionários foram realocados para outras áreas ou não houve a reposição no caso de aposentadorias. Sendo assim, seu índice de produtividade atual está em $24,5 \%$ acima do período anterior.

Inventário - Possui dois indicadores: o de estoque em mãos, que deve ser inferior a dois meses, e o percentual de itens com movimentação inferior ao período de seis meses a um ano (itens lentos) e de movimentação inferior a mais de um ano (itens obsoletos), que devem ser menores que 20\%. tualmente, a empresa está com um índice de 2,2 meses em estoque em mãos e com um percentual de $40 \%$ de itens lentos e obsoletos. Em relação ao período anterior 
houve uma melhora no estoque em mãos, que era de 2,9 meses. O percentual de itens lentos e obsoletos do período anterior era de $29 \%$, portanto houve uma redução em valores absolutos, mas um aumento do percentual com a diminuição do estoque total.

5S - A empresa está em um processo contínuo de implementação dos $5 \mathrm{~S}$ progressivos. Semanalmente são executadas auditórias em todas as áreas e nota-se uma grande melhoria do ambiente de trabalho. Em comparação ao ano anterior foi relatado maior organização, limpeza e os equipamentos e máquinas são utilizados com maior frequência. Foi comprovada a existência de uma área livre disponível de 250 metros quadrados referente à implementação dos $5 \mathrm{~S}$.

\subsubsection{Quadro Sumário dos Resultados}


Quadro 8 - Quadro sumário dos resultados

\begin{tabular}{|c|c|c|c|c|c|}
\hline Caso & $\begin{array}{c}\text { Grau de } \\
\text { Enxugamento } \\
\text { pela norma } \\
\text { SAE J4000 }\end{array}$ & $\begin{array}{l}\text { Manufatura } \\
\text { Enxuta }\end{array}$ & $\begin{array}{l}\text { Tecnologia da } \\
\text { Informação } \\
\text { (TI) }\end{array}$ & $\begin{array}{c}\text { Relacionamento } \\
\text { ME e TI }\end{array}$ & $\begin{array}{l}\text { Indicadores } \\
\text { Operacionais }\end{array}$ \\
\hline A & $39 \%$ & $\begin{array}{l}\text { Ferramentas } \\
\text { adotadas: } \\
\text { Sistema Puxado; } \\
\text { Trabalho } \\
\text { Padronizado. } \\
\text { Ferramentas em } \\
\text { implementação: } \\
\text { Kaizen; } \\
\text { Setup rápido; } \\
\text { Heijunka. } \\
\text { Ferramentas não } \\
\text { adotadas: } \\
\text { 5S; } \\
\text { TPM; } \\
\text { Mapeamento do } \\
\text { fluxo de valor. }\end{array}$ & $\begin{array}{l}\text { ERP: } \\
\text { Totvs, mudança } \\
\text { para Dynamics. } \\
\text { BI: } \\
\text { Não utiliza. } \\
\text { Pessoal de TI: } \\
\text { Equipe para } \\
\text { Desenvolviment } \\
\text { o local. }\end{array}$ & $\begin{array}{l}\text { Introdução de coletores } \\
\text { de informação nas } \\
\text { linhas de produção que } \\
\text { atualizam em tempo } \\
\text { real o estágio da } \\
\text { operação; } \\
\text { Uso de computadores } \\
\text { pelos líderes de células } \\
\text { na obtenção de } \\
\text { informações gerenciais } \\
\text { em tempo real; } \\
\text { Novo apontamento do } \\
\text { kanban e monitores } \\
\text { com indicadores de } \\
\text { tempo tak e } \\
\text { produtividade nas } \\
\text { linhas que determinam } \\
\text { o ritmo de produção. }\end{array}$ & $\begin{array}{l}\text { Qualidade: } \\
\text { Redução de 35\% } \\
\text { nas reclamações } \\
\text { dos clientes. } \\
\text { Entrega: } \\
\text { atendimento do } \\
\text { prazo de } 80-85 \% \\
\text { para 95-99\%. } \\
\text { Custo: } \\
\text { Redução da mão de } \\
\text { obra, mas não é } \\
\text { relevante. } \\
\text { Inventário: } \\
\text { Redução do } \\
\text { inventário em } \\
\text { processo. } \\
\text { 5S: } \\
\text { Somente na linha } \\
\text { piloto. }\end{array}$ \\
\hline B & $46 \%$ & $\begin{array}{l}\text { Ferramentas } \\
\text { adotadas: } \\
\text { Sistema Puxado; } \\
\text { Kaizen; } \\
\text { 5S; } \\
\text { Mapeamento do } \\
\text { fluxo de valor; } \\
\text { Heijunka. } \\
\text { Ferramentas em } \\
\text { implementação: } \\
\text { TPM; } \\
\text { Setup rápido; } \\
\text { Trabalho } \\
\text { Padronizado. }\end{array}$ & $\begin{array}{l}\text { ERP: } \\
\text { Omega da } \\
\text { ABC71 } \\
\text { BI: } \\
\text { SADIG } \\
\text { Pessoal de TI: } \\
\text { Consultores do } \\
\text { ERP e pessoal } \\
\text { terceirizado. }\end{array}$ & $\begin{array}{l}\text { Módulo de gestão do } \\
\text { estoque do ERP auxilia } \\
\text { na elaboração e revisão } \\
\text { dos Kanbans; } \\
\text { Utilização do módulo } \\
\text { de ativo fixo do ERP } \\
\text { para auxílio da gestão } \\
\text { do TPM; } \\
\text { Gestão dos indicadores } \\
\text { operacionais através de } \\
\text { relatórios } \\
\text { desenvolvidos no ERP } \\
\text { e consultas no BI; } \\
\text { Uso de computadores } \\
\text { pelos líderes para } \\
\text { obtenção de } \\
\text { informações, como } \\
\text { atendimento a pedidos } \\
\text { e índices de } \\
\text { desempenho em tempo } \\
\text { real. }\end{array}$ & $\begin{array}{l}\text { Qualidade: } \\
\text { Redução do índice } \\
\text { de reclamação (76 } \\
\text { ppm). } \\
\text { Entrega: } \\
\text { Prazo de entrega era } \\
\text { de } 30 \text { a } 45 \text { dias, } \\
\text { atualmente é de } 3 \\
\text { dias. } \\
\text { Custo: } \\
\text { Produtividade } \\
24,5 \% \text { acima do } \\
\text { período anterior. } \\
\text { Inventário: } \\
\text { Redução do } \\
\text { inventário de 2,9 } \\
\text { para 2,2 meses. } \\
\text { 5S: } \\
\text { Auditoria semanal, } \\
\text { como resultado } \\
\text { obteve-se } 250 \\
\text { metros quadrados } \\
\text { de área disponível. }\end{array}$ \\
\hline
\end{tabular}

Fonte: Autor. 


\section{DISCUSSÃO DOS RESULTADOS}

Segundo Riezebos, Klingenberg e Hicks (2009), as abordagens da manufatura enxuta e tecnologia da informação são cada vez mais interdependentes e complementares e podem trazer um diferencial em termos de desempenho. Os casos analisados indicam que a TI auxiliou na execução das práticas da manufatura enxuta, o que resultou na melhora dos indicadores operacionais das empresas.

Para Powell e Strandhagen (2011), a manufatura enxuta e os sistemas ERP são considerados duas das estratégias muito utilizadas em empresas com o objetivo de melhorar seu desempenho, entretanto observa-se um paradoxo entre os sistemas ERP e da manufatura enxuta. Nota-se que ambas as empresas possuem ERP que são utilizados para integração de suas áreas e implementaram a manufatura enxuta. Como ambos os pacotes ERP são baseados em uma produção empurrada, e não puxada, as duas empresas adaptaram seus módulos de gestão industrial e estoque e automatizaram, através de leitores de código de barras, a coleta de informações no chão de fábrica.

As empresas compreendem a necessidade do relacionamento entre a tecnologia da informação e as práticas da manufatura enxuta. A primeira auxilia a integrar todas as áreas e automatiza as atividades e processos reduzindo seu tempo de execução, enquanto a segunda promove as melhores práticas de produção, buscando uma melhoria contínua. Como resultado, os gestores indicam a melhora dos indicadores de desempenho operacional das empresas (KHANCHANAPONG et al., 2014).

O caso B adotou a ferramenta SADIG na análise das atividades diárias e auxiliando no controle dos indicadores de desempenho operacional utilizados no controle da implementação da manufatura enxuta, conforme citado por White (2006).

Com relação à manufatura enxuta e conforme a norma SAE J4000, as empresas possuem seus graus de enxugamento muito próximos (39\% e 46\%). Um ponto em comum entre elas, com referência à implementação das ferramentas da manufatura enxuta, é que ambas iniciaram aplicando um sistema puxado em seu processo produtivo. Na empresa A observou-se que houve uma grande alteração do processo produtivo, por esse motivo trabalha fortemente na implementação de um sistema puxado e no trabalho padronizado. Já na empresa B, além do foco no sistema puxado, na utilização de cartões Kanban e nos quadros Heijunka, existe um grande esforço na implementação de indicadores para auxiliar no controle e mensuração das melhorias proporcionadas pelos eventos Kaizen. 
A tecnologia da informação está presente em ambas as empresas com a implementação de sistemas ERP integrando todas as suas áreas. A empresa A possui uma equipe de desenvolvimento local enquanto que a B utiliza consultores terceirizados.

Por meio dos casos analisados observou-se que tanto os colaboradores como os gestores das empresas têm a percepção de que a tecnologia da informação auxilia na implantação da manufatura enxuta. A empresa A tem como filosofia de implementação primeiro ensinar e aplicar a ferramenta da manufatura enxuta e só após o conceito estar bem consolidado é que existe o estudo para a automação e aplicação da tecnologia da informação. $\mathrm{Na}$ empresa B a tecnologia da informação é utilizada pelos colaboradores e gestores como uma ferramenta que auxilia a implementação da manufatura enxuta; como exemplo, é possível citar o cálculo dos cartões Kanban e Heijunka e a alteração do sistema de entrada de pedidos e faturamento do ERP clássico implementado que empurra a produção para um sistema puxado de produção.

Em ambas as empresas se observou que os indicadores operacionais melhoram em grau acentuado após a manufatura enxuta, que utiliza a tecnologia da informação para sua implementação, automação de processo e gestão do processo produtivo.

Trazendo a discussão para o alinhamento estratégico da TI e negócios, observa-se que a empresa A possui diferença da empresa B no que se refere ao aspecto do papel da TI. A empresa A possui um time local com foco no alinhamento dos processos de negócio e a tecnologia da informação. Para a Empresa B, a TI tem um papel de suporte e não possui uma equipe local para desenvolvimento de ferramentas.

As ferramentas de TI que estão sendo trabalhadas pelas empresas A e B disponibilizam as informações em tempo real sobre a produtividade e a qualidade do que está sendo produzido. No caso A, a gestão visual efetuada através de monitores informa em tempo real a produtividade e as falhas de qualidade para evitar a propagação do "erro". Com apontamentos em tempo real a fábrica possui informações atualizadas instantaneamente de quantidade produzida, tempos e previsão de término, permitindo ações corretivas e a execução dos objetivos da manufatura enxuta.

Analisando as proposições elaboradas para o desenvolvimento da pesquisa, os casos indicaram que:

Proposição 1. As empresas precisam compreender o relacionamento da tecnologia de informação e as práticas da manufatura enxuta com o propósito de melhorar o seu desempenho operacional (KHANCHANAPONG et al., 2014). 
O caso A apresenta aderência a esta proposição, em contrapartida, o caso B menciona que a TI representa um suporte e está voltado para o atendimento às questões de legislação, por exemplo. Os benefícios e a integração da TI aos objetivos da manufatura enxuta refletem uma postura da gestão local e não corporativa para o caso B. A empresa A apresenta um alinhamento estratégico de TI e Negócios, evidenciando uma posição corporativa.

Proposição 2. A manufatura enxuta e os sistemas ERP são considerados duas das estratégias utilizadas em empresas com o objetivo de melhorar seu desempenho, mas se observa paradoxo entre os sistemas ERP e da manufatura enxuta (POWELL; STRANDHAGEN, 2011).

Em ambos os casos os gestores discutem as funcionalidades do ERP e sua falta de alinhamento para um ambiente de manufatura enxuta. Adaptações foram necessárias para o uso efetivo do sistema em ambas as empresas.

Proposição 3. Apesar das soluções de BI enfatizarem sua aplicação em análises dos tipos estratégicas e táticas que são mais voltadas ao médio e longo prazo, com a difusão dos sistemas de informações nas organizações, o BI pode ser também do tipo operacional e voltado para análises das atividades diárias e apoiar a implementação da manufatura enxuta (WHITE, 2006).

A empresa B apresenta aderência a esta proposição, já a empresa A não utiliza formalmente uma ferramenta de BI.

\subsection{CONTRIBUIÇÕES GERENCIAIS}

Verificou-se o cuidado com a introdução e disseminação dos conceitos da manufatura enxuta bem como com a mudança cultural da empresa causada pela implementação da nova filosofia. Somente após a compreensão dos conceitos por parte dos colaboradores é que a tecnologia da informação deve ser implantada para a automatização e simplificação dos novos processos baseados na manufatura enxuta.

Em ambos os casos, também se observou a necessidade de informações em tempo real para auxílio na tomada de decisões, sendo que o uso de leitores de código de barras para os apontamentos produtivos é uma prática utilizada.

Outros exemplos observados nos casos foram o uso de monitores no final da linha de produção informando o tempo tak e previsões de demanda, o que garante o ritmo no processo 
produtivo, e a utilização do módulo de gestão do estoque para auxiliar na definição e revisão das quantidades de produtos nos cartões Kanban.

\subsection{SUGESTÃO PARA TRABALHOS FUTUROS}

Como sugestão para trabalhos futuros, que possam aperfeiçoar a pesquisa realizada, é possível expandir e refazer a comparação entre a implementação da manufatura enxuta e a aplicação da tecnologia da informação verificando se houve uma melhoria dos indicadores de desempenho organizacionais ao invés dos indicadores operacionais.

Outra oportunidade de trabalho são estudos específicos para adaptar os módulos de gestão da produção dos ERP de mercado, que contemplam uma produção empurrada, para a filosofia da manufatura enxuta, que está fundamentada em uma produção de fluxo puxado com a eliminação de estoques em processo e criação de supermercados.

Finalmente, sugere-se estudos específicos de como a tecnologia da informação pode auxiliar na implementação das ferramentas da manufatura enxuta, automatizando rotinas repetitivas e auxiliando na análise dos indicadores de performance, além de servir como base de conhecimento para a disseminação das melhores práticas do conhecimento enxuto gerado dentro e fora da organização. 


\section{CONCLUSÃO}

A tecnologia contribui para as práticas da manufatura enxuta, principalmente no aspecto da obtenção das informações em tempo real na produção, na automação de processos operacionais e no reporte dos indicadores de desempenho. Ela representa um fator importante na execução da manufatura enxuta e no desempenho operacional, contribuindo para a redução de perdas, eliminação de erros e verificações redundantes. Proporciona flexibilidade para modelar e alterar processos complexos e, em seguida, aplicá-las imediatamente. Fornece feedback em tempo real para identificar e resolver rapidamente questões que inibem a melhoria de produtos e processos.

Nesse sentido, torna-se fundamental um alinhamento da TI e Negócios, permitindo capturar as alterações necessárias nos processos e sua respectiva automação para a execução das práticas da manufatura enxuta de forma eficaz. O desenvolvimento local de ferramentas e a presença de uma equipe de TI pode criar um ambiente favorável para uma integração da TI e a implementação das ferramentas da manufatura enxuta, conforme indicou o estudo de caso A.

Foi possível notar, também, uma necessidade de adaptar os sistemas ERP existentes no mercado, que em seus módulos de produção desenvolvem um processo empurrado, e não o puxado, um dos pilares da manufatura enxuta, conforme indicou o estudo de caso B.

A competência avançada da área de TI é uma capacidade valiosa que integra os investimentos de TI à implementação da manufatura enxuta. Verificou-se que o investimento em TI é um dos requisitos para uma boa execução das práticas da manufatura enxuta. A implementação dessas práticas alinhadas com a TI pode refletir em melhores indicadores em termos de entrega, qualidade e redução de estoque em processo. 


\section{REFERENCIAS}

ACHANGA, P. et al. Critical success factors for lean implementation within SMEs. Journal of Manufacturing Technology Management, v. 17, n. 4, p. 460-471, 2006.

ALLIO, M. Metrics that Matter. v. 7, Badford, Emerald Group, 2006, p. 255-263.

ANTONELLI, L.G.G. Estudo sobre a medição de desempenho enxuta como ferramenta de adequação de sistemas de produção às condições projetadas. São Carlos - USP, 2008.

BELL, S. Lean enterprise systems: using IT for continuous improvement. John Wiley \& Sons, 2005.

BEZERRA, D. K. Aplicação do método de nivelamento de produção e demanda em empresas de tipologia de produção ETO com baixo volume e alta diversidade de produtos. 94f. 2008. Trabalho de Conclusão de Curso (Engenharia de Produção Mecânica), Universidade São Paulos, São Carlos, SP, 2008.

BHASIN, S. Lean and performance measurement. Journal of Manufacturing Technology Management, v. 19, n. 5, p. 670-684, 2008.

BHARADWAJ, A. S. A resource-based perspective on information technology capability and firm performance: an empirical investigation. MIS quarterly, p. 169-196, 2000.

BICHENO, J. Lean Toolbox. Londres: Picsie, 2004.

BLACK, J. T. O Projeto da Fábrica com Futuro. Porto Alegre: Bookman, 1998.

BROSNAHAN, J. P. Unsleash the Power of Lean Accounting. Journal of Accountancy, p. 60-66, jul. 2008.

CHAVES FILHO, J. G. B. Aplicação da padronização do método de trabalho segundo uma metodologia baseada na produção enxuta: em estudo de caso. $64 \mathrm{f} 2007$. Trabalho de Conclusão de Curso (Engenharia de Produção), Universidade de São Paulo, São Carlos, SP, 2007.

CHOU, D. C; TRIPURAMALLU, H. B. BI and ERP integration. Information Management \& Computer Security, v. 13, n. 5, p. 340-349, 2005.

COTTYN, J. et al. A method to align a manufacturing execution system with Lean objectives. International Journal of Production Research, p. 4397-4413, 2011.

DENNIS, P. Produção Lean Simplificada. 2. ed. Porto Alegre: Bookman, 2008.

DIMANCESCU, D., HINES, P.; RICH, N. The Lean Enterprise, Nova York, Amazon, 1997.

FRIGO, M. Performance measures that drive the goal Tenets of strategy. Strategic Finance, v. 85 , p. 9-13, 2003. 
GAITHER, N.; FRAZIER, G. Administração da produção e operações. 8. ed. São Paulo: Thompson Learning, 2006.

GALGANO, A. Las tres revoluciones. Caza del desperdicio: doblar la productividad con la "LEAN Production". Madri: Ediciones Díaz de Santos, 2003.

GOLDMAN, H. H. The origins and development of quality initiatives in American business. The TQM Magazine, v. 17, n. 3, p. 217-225, 2005.

GONÇALVES, R. C. M. G.; RICCIO, E. L. Sistema de Informação: ênfase em Controladoria e Contabilidade. São Paulo. Atlas. 2009.

HABERKAMP, A. M. et al. Impacto dos investimentos em tecnologia da informação (TI) nas variáveis estratégicas das empresas prestadoras de serviços contábeis. BASE - Revista de Administração e Contabilidade da Unisinos, v. 7, n. 2, p. 149-161, 2010.

HARTONO, E. et al. The role of the quality of shared information in interorganizational systems use. International Journal of Information Management, v. 30, n. 5, p. 1-9, 2010.

HENDERSON, J.; VENKATRAMAN, N. Strategic Alignment: Leveraging Information Technology for Transforming Organizations. IBM Systems Journal, v. 32, n. 1, 1993.

HUTCHINS, D. Introducing TPM. Manufacturing Engineer, v. 20, 1998.

HWANG, Y. -D. The practices of integrating manufacturing execution systems and Six Sigma methodology. International Journal of Advanced Manufacturing Technologies, v. 31, p. 145-154, 2006.

JACOB, F.; CHASE, R.; AQUILANO, N. Operations \& Supply Management. 12. ed., Nova York, McGraw-Hill/Irwin, 2009.

KAPLAN, R. S.; NORTON, D. P. The balanced scorecard - measures that drive performance. Harvard Business Review, v. 70, p. 71-80, 1992. $\overline{\text { p. } 134-42, \overline{1993 .} .}$ Putting the balanced scorecard to work. Harvard Business Review, v. 71, $\frac{1}{2005 .}$; $ـ$ The Office of Strategy Management. Harvard Business Review, p. 72-80,

KHANCHANAPONG et al. The unique and complementary effects of manufacturing technologies and lean practices on manufacturing operational performance. International Journal of Production Economics, v. 153, p. 191-203, 2014.

LAUDON, K. C.; LAUDON J. P. Sistemas de informação gerenciais: administrando a empresa digital. 9. ed. São Paulo: Prentice Hall, 2010.

LAWSON, R.; STRATTON, W.; HATCH, T. The benefits of a scorecard system. CMA Management, v. 77, p. 24-29, 2003. 
LIAN, Y.; VAN LANDEGHEM, H. Analyzing the effects of Lean manufacturing using a value stream mapping- based simulation generator. International Journal of Production Research, v. 45, n. 13, p. 267-275, 2007.

LIKER, J. K. O modelo Toyota, 14 princípios de gestão do maior fabricante do mundo. Porto Alegre: Bookman, 2005.

LIKER, J. K.; MEIER, D. O modelo Toyota, manual de aplicação. Porto Alegre: Bookman, 2006.

LOVELOCK, C.; WRIGHT, L. Serviços: marketing e gestão. São Paulo: Saraiva, 2006.

LUCANO, W.C.; MAESTRELLI, N.C.; VIEIRA, JR.M. Determinação do grau de enxugamento de uma empresa: uma proposta conceitual. Encontro da AnPAD, 28, Curitiba, PR, 2006

MALONE, T.; SINNETT, W. Performance management. Financial Executive, v. 21, p. 6063, 2005.

MALTZ, A.; SHENHAR, A.; REILLY, R. Beyond the balanced scorecard: refining the search for organizational success measures. Long Range Planning, v. 36, p. 187-204, 2013.

MARSHALL, J.; HEFFES, E. Performance measures go beyond financials. Financial Executive, v. 20, p. 11-12, 2004.

MARTINS, G. A.; THEÓPHILO, C. R. Metodologia da investigação científica para ciências sociais aplicadas. 2. ed. São Paulo: Atlas, 2009.

MASKELL, B.; BAGGALEY, B.; GRASSO, L. Practical lean accounting: a proven system for measuring and managing the lean enterprise. CRC Press, 2011.

MENDES, J. V.; ESCRIVÃO FILHO, E. Sistemas integrados de gestão (ERP) em pequenas e medias empresas: um confronto entre o referencial teórico e a prática empresarial. $\mathbf{G \& P}$ Gestão e Produção, v. 9, p. 277-296, 2002.

MEYER, H. Manufacturing execution systems, optimal design, planning and deployment. Nova York: McGrawHill, 2009.

MOYANO-FUENTES, J.; SACRISTÁN-DÍAZ, M. Learning on lean: a review of thinking and research. International Journal of Operations \& Production Management, v. 32, n. 5, 2012.

NEELY, A. The performance measurement revolution: why now and where next. International Journal of Operations and Production Management, v. 19, n. 2, p. 205-228, 1999. 
NEELY, A.; GREGORY, M.; PLATTS, K. The evolution of performance measurement research: Developments in the last decade and a research agenda for the next. International Journal of Operations \& Production Management, v. 25, n. 12, 2005.

O'BRIEN, J. A. Sistemas de informação e as decisões gerenciais na era da internet. São Paulo: Saraiva, 2002.

OHNO, T. O Sistema Toyota de Produção: além da produção em larga escala. Porto Alegre: Editora Bookman, 1997.

PEÇAS, P.; HENRIQUES, E. Best Practices of Collaboration Between University and Industrial SMEs. Benchmarking, An International Journal, v. 13, n. 1-2, 2006.

POWELL, D.; STRANDHAGEN, J. O. Lean Production Vs. ERP Systems: An ICT Paradox? Operations Management, v. 37, p. 31-36, 2011.

POWELL, D.; RIEZEBOS, J.; STRANDHAGEN, J. O. Lean production and ERP systems in smalland medium-sized enterprises: ERP support for pull production. International Journal of Production Research, v. 51, n. 2, p. 395-409, 2012.

QUEIROZ, J. A.; RENTES, A. F.; ARAUJO, C. A. Transformação enxuta: aplicação do mapeamento do fluxo de valor em uma situação real. 2009.

RABAGLIO, M. O. Ferramentas de avaliação de performance com foco em competências. Qualitymark, 2006.

RASTEIRO, G. Estudo sobre a aplicação da tecnologia RFID em sistemas de Kanban eletrônico. 72f. 2009. Trabalho de Conclusão de Curso (Engenharia de Mecatrônica), Universidade de São Paulo, São Carlos, SP, 2009.

RIEZEBOS, J.; KLINGENBERG, W.; HICKS, C. Lean Production and information technology: connection or contradiction? Computers in Industry, v. 60, n. 4, p. 237-247, 2009.

ROTHER, M.; SHOOK, J. Aprendendo a enxergar: mapeando o fluxo de valor para agregar valor e eliminar o desperdício. São Paulo: Lean Institute Brasil, 2003.

SOCIETY FOR AUTOMOTIVE ENGINEERS. SAE J4000: Identification and measurement of best practice in implementation of lean operation. Warrendale, PA, 1999a.

SOCIETY FOR AUTOMOTIVE ENGINEERS. SAE J4001: Implementation of lean operation user manual. Warrendale, PA, 1999b.

SAENZ, U. B.; ARTIBA, A.; PELLERIN, R. Manufacturing execution system: a literature review. Production Planning \& Control, v. 20, n. 6, p. 525-539, 2009.

SAIA, R. O Lean Manufacturing aplicado em ambientes de produção engineer to order. 81f. 2009. Trabalho de Conclusão de Curso (Engenharia de Produção Mecânica), Universidade de São Paulo, São Carlos, SP, 2009. 
SANCHES, A. M.; PEREZ, M. P. Lean indicators and manufacturing strategies. International Journal of Operations \& Production Management, MCB University Press, n. 11, p.1433-1451, 2001.

SANJAY, B. Lean and performance measurement, Journal of Manufacturing Technology Management, Vol. 19 Iss: 5, pp.670 - 684, 2008.

SANTOS, M. F. et al. Towards a definition of a business performance measurement system. International Journal of Operations \& Production Management, v. 27, n. 8, p. 784-801, 2007.

SEDANO, J. et al. Optimising Operational Costs Using Soft Computing Techniques. 4. ed. Burgos: IOS Press, 2011.

SHAH, R.; WARD, P. Lean manufacturing: context, practice, bundles and performance, Journal of Operations Management, v. 21, p. 129-49, 2003.

SHEPHERD, C.; GÜNTER, H. Measuring supply chain performance: current research and future directions. International Journal of Productivity and Performance Management, v. 55, n. 3-4, p. 242-258, 2006.

SILVA, T. D. Estudo sobre Sistema de Medição de Desempenho Baseado nas Ferramentas da Produção Enxuta. 153f. 2007. Dissertação (Mestrado em Engenharia de Produção), Universidade de São Paulo, São Carlos, SP, 2007.

SLACK, N.; CHAMBERS, S.; JOHNSTON, R. Administração da produção. São Paulo: Atlas, 2002.

SOUZA, C. A.; ZWICKER, R. ERP systems' life cycle: findings and recommendations from a multiple-case study in Brazilian companies. In: BALAS ANNUAL CONFERENCE, 2001, San Diego. Proceedings... San Diego: BALAS, 2001.

STANDARD, C.; DAVIS, D. Running today's factory: a proven strategy for lean manufacturing. Cincinnati: Hanser Gardner Publications, 2000.

STEFANELli, P. Utilização da Contabilidade dos Ganhos como Ferramenta para Tomada de Decisão em um Ambiente com Aplicação dos Conceitos de Produção Enxuta. 74f. 2007. Trabalho de Conclusão de Curso (Engenharia de Produção Mecânica), Universidade de São Paulo, São Carlos, SP, 2007.

SUGAI, M.; MCINTOSH, R. I.; NOVASKI, O. Metodologia de Shigeo Shingo (SMED): análise crítica e estudo de caso. Gestão \& Produção, p. 323-335, 2007.

TALLON, P. P. A Service Science Perspective on Strategic Choice, IT, and Performance in U.S. Banking. Journal of Management Information Systems, v. 26, n. 4, p. 219-252, 2010.

TALLON, P. P.; KRAEMER, K. Fact or Fiction? A Sensemaking Perspective on the Reality Behind Executives' Perceptions of IT Business Value. Journal of Management Information Systems, v. 24, n. 1, p. 13-54, 2007. 
TANGEN, S. Analysing the requirements of performance measurement systems. Measuring Business Excellence, v. 9, p. 46-54, 2005.

WAN, H. -D.; CHEN, F. F. A. Web-based Kanban system for job dispatching, tracking, and performance monitoring. International Journal of Advanced Manufacturing Technologies, v. 38, n. 9-10, p. 995-1005, 2007.

WARD, P.; ZHOU, H. Impact of Information Technology Integration and Lean/Just-In-Time Practices on Lead-Time Performance. Decision Sciences, v. 37, n. 2, p. 177-203, 2006.

WHITE, C. New CIO spending survey. 2006. Disponível em: <http://www.b-eyenetwork.co.uk/blogs/archives/2006/09/new_cio_spending_survey.php $>$. Acesso em: 7 set. 2016.

WOMACK, J. P.; JONES, D. Lean thinking: banish waste and create wealth in your corporation. New York: Simon \& Schuster, 1996.

WOMACK, J. P.; JONES, D. T.; ROOS, D. A Máquina que mudou o mundo. 14. ed. Rio de Janeiro: Campus, 1992.

YENIYURT, S. A literature review and integrative performance measurement framework for multinational companies. Marketing Intelligence \& Planning, v. 21, p. 134-42, 2003.

YIN. R. K.. Estudo de caso: planejamento e métodos. 4. ed. Porto Alegre: Bookman, 2010. 


\section{APÊNDICE}

\section{Apêndice A - Base para avaliação do nível da implantação da manufatura enxuta}

Em agosto de 1999 a SAE (Society for Automotive Engineers) aprovou a norma SAE J4000, intitulada "Identificação e mensuração de melhores práticas na implementação de uma operação enxuta". Essa norma objetiva identificar e medir melhores práticas na implementação de uma operação enxuta em uma organização industrial. Ela foi complementada em novembro de 1999 pela SAE J4001, denominada "Manual do usuário para a implementação de uma operação enxuta", a qual fornece instruções para avaliar o nível de atendimento das organizações à norma SAE J4000 (LUCATO; MAESTRELLI; VIEIRA JR. , 2006; SAE 1999a, 1999b).

A norma SAE J4000 é o primeiro documento e elenca critérios pelos quais a manufatura enxuta poderá ser alcançada, sempre enfocando a eliminação ou minimização de desperdícios para se tornar uma empresa enxuta. A seção principal da norma é composta de 52 componentes divididos em seis elementos que avaliam o grau de implantação dos princípios de operações enxutas em uma empresa. Cada elemento da norma tem como objetivo avaliar um aspecto da organização, a saber:

a) Elemento 4 (Gerência e confiabilidade) - analisa o reconhecimento e envolvimento da direção e alta gerência junto ao Sistema e se as iniciativas disseminadas por eles estão sendo implementadas junto ao planejamento estratégico da organização. Esse planejamento deve ser complementado com um acompanhamento das ações e resultados obtidos, fomentando a colaboração de todos os envolvidos e premiando-os segundo critérios claros e conhecidos, quando avanços e sucessos são obtidos pela organização;

Quadro 1 - Questões do Elemento 4

\begin{tabular}{|c|l|}
\hline Elemento & \multicolumn{1}{|c|}{ Questão } \\
\hline 4.1 & $\begin{array}{l}\text { Melhoria contínua na implantação de métodos operacionais Lean é a principal ferramenta na } \\
\text { perseguição dos objetivos estratégicos da empresa? }\end{array}$ \\
\hline 4.2 & $\begin{array}{l}\text { Técnicas de desdobramentos de políticas estruturadas são usadas para planejar ações de } \\
\text { desdobramentos Lean da organização? }\end{array}$ \\
\hline 4.3 & Objetivos de progresso Lean são definidos e estão sendo efetivamente comunicados? \\
\hline 4.4 & $\begin{array}{l}\text { Conhecimento da filosofia e mecanismos de operação Lean estão sendo obtidos e efetivamente } \\
\text { comunicados? }\end{array}$ \\
\hline 4.5 & $\begin{array}{l}\text { Os gerentes sêniores (neste caso, os principais executivos) da empresa estão ativamente } \\
\text { liderando o desdobramento de práticas Lean? }\end{array}$ \\
\hline
\end{tabular}




\begin{tabular}{|c|l|}
\hline 4.6 & $\begin{array}{l}\text { O Progresso Lean é revisado pelos gerentes sêniores contra os objetivos planejados } \\
\text { regularmente? }\end{array}$ \\
\hline 4.7 & Incentivos significativos que recompensem progressos Lean organizacionais existem? \\
\hline 4.8 & $\begin{array}{l}\text { O desempenho individual de gerentes é avaliado e recompensado em relação aos progressos } \\
\text { Lean? }\end{array}$ \\
\hline 4.9 & $\begin{array}{l}\text { Existe uma atmosfera organizacional com o foco nos processos, orientadas ao desempenho e que } \\
\text { não culpe pessoas? }\end{array}$ \\
\hline 4.10 & $\begin{array}{l}\text { Há um envolvimento pessoal e regular dos gerentes sêniores com os operários (funcionários } \\
\text { operacionais) com foco nas práticas Lean? }\end{array}$ \\
\hline 4.11 & $\begin{array}{l}\text { Política consistente visando à criação de estrutura organizacional (pessoas/funções) que garanta } \\
\text { o progresso Lean existe e é seguida? }\end{array}$ \\
\hline 4.12 & $\begin{array}{l}\text { Nenhum funcionário possui razão em perceber que sua individualidade é colocada em risco por } \\
\text { contribuir para o progresso Lean? (Esta pergunta tem o objetivo verificar se há coação aos } \\
\text { funcionários) }\end{array}$ \\
\hline 4.13 & $\begin{array}{l}\text { Os gerentes optam por aderir aos princípios Lean quando confrontados com objetivos } \\
\text { operacionais de curto prazo, inconsistentes com o progresso Lean? }\end{array}$ \\
\hline
\end{tabular}

Fonte: Norma SAE J4000.

b) Elemento 5 (Pessoas e RH) - verifica o nível de participação de todos da organização para o sucesso do Sistema. Esse esforço é analisado pela norma por meio da democratização da tomada de decisões, de uma maior autonomia, formação de equipes interdisciplinares, treinamento e garantia dos recursos para as ações dessas equipes;

Quadro 2 - Questões do Elemento 5

\begin{tabular}{|c|c|}
\hline Elemento & Questão \\
\hline 5.1 & $\begin{array}{l}\text { Recursos adequados de treinamento são providos e o tempo de treinamento remunerado está } \\
\text { disponível para funcionários? }\end{array}$ \\
\hline 5.2 & $\begin{array}{l}\text { O programa de treinamento inclui treinamentos específicos de ferramentas Lean e quantificados } \\
\text { conforme as necessidades da empresa, para todos os níveis dentro da organização? }\end{array}$ \\
\hline 5.3 & $\begin{array}{l}\text { Os treinamentos são conduzidos conforme planejados, registros são mantidos e a eficácia dos } \\
\text { treinamentos é avaliada regularmente? }\end{array}$ \\
\hline 5.4 & $\begin{array}{l}\text { A Organização está estruturada de maneira correspondente ao fluxo de valor através da } \\
\text { empresa? }\end{array}$ \\
\hline 5.5 & Cada funcionário participa na estrutura de forma correspondente à sua função? \\
\hline 5.6 & $\begin{array}{l}\text { Mão de obra, políticas trabalhistas e acordos (sindicais e diretos) existentes permitem o } \\
\text { progresso Lean na organização? }\end{array}$ \\
\hline 5.7 & Liderança da equipe e níveis de responsabilidade estão claramente definidos? \\
\hline 5.8 & $\begin{array}{l}\text { Desenvolvimento de trabalhadores através de círculos da qualidade (ou times de melhoria } \\
\text { contínua) é encorajado e apoiado em todos os níveis da empresa? }\end{array}$ \\
\hline 5.9 & Times são responsabilizados por melhoria contínua em suas etapas no fluxo de valor? \\
\hline 5.10 & $\begin{array}{l}\text { Autoridade da tomada de decisão por equipes e autoridade para agir correspondem ao nível da } \\
\text { responsabilidade da equipe? }\end{array}$ \\
\hline 5.11 & $\begin{array}{l}\text { O gerente não se sobrepõe à decisão e às ações da equipe quando essas estão dentro do nível de } \\
\text { autoridade da equipe? }\end{array}$ \\
\hline 5.12 & $\begin{array}{l}\text { O gerente apoia a decisão e as ações da equipe quando essas demandam recursos, consistentes } \\
\text { com as boas práticas de negócios? }\end{array}$ \\
\hline
\end{tabular}

Fonte: Norma SAE J4000.

c) Elemento 6 (Sistema de Informação) - constata se a empresa garante acesso seguro e estruturado às informações úteis e necessárias para a tomada de 
iniciativas voltadas à obtenção de uma manufatura enxuta. Essas informações devem facilitar a análise das situações sob estudo e, principalmente, possibilitar o acompanhamento do desempenho das ações tomadas pelas equipes;

Quadro 3 - Questões do Elemento 6

\begin{tabular}{|c|l|}
\hline Elemento & \multicolumn{1}{|c|}{ Questão } \\
\hline 6.1 & $\begin{array}{l}\text { Informações operacionais adequadas e precisas estão disponíveis para os membros da } \\
\text { organização conforme necessárias? }\end{array}$ \\
\hline 6.2 & Conhecimento é compartilhado através da organização? \\
\hline 6.3 & $\begin{array}{l}\text { Coleta de dados e sua utilização são de responsabilidade dos indivíduos mais próximos com o } \\
\text { correspondente estágio do processo? }\end{array}$ \\
\hline 6.4 & $\begin{array}{l}\text { O sistema financeiro em operação está estruturado para apresentar corretamente o resultado do } \\
\text { progresso Lean? }\end{array}$ \\
\hline
\end{tabular}

Fonte: Norma SAE J4000.

d) Elemento 7 (Relação Cliente/Fornecedor e Organização) - julga a relação de parceria entre fornecedor, organização e cliente, verificando o envolvimento desses em áreas tais como desenvolvimento de produtos e o estabelecimento de parcerias duradouras;

Quadro 4 - Questões do Elemento 7

\begin{tabular}{|c|l|}
\hline Elemento & \multicolumn{1}{|c|}{ Questão } \\
\hline 7.1 & $\begin{array}{l}\text { Fornecedores e clientes participam nas fases iniciais da empresa relacionadas aos projetos e } \\
\text { desenvolvimento de processos e produtos? }\end{array}$ \\
\hline 7.2 & $\begin{array}{l}\text { Fornecedores e clientes estão apropriadamente representados nas equipes da organização } \\
\text { relacionadas aos projetos, processos e produtos? }\end{array}$ \\
\hline 7.3 & $\begin{array}{l}\text { Fornecedores e clientes participam das revisões regulares do progresso de projetos, processos e } \\
\text { produtos? }\end{array}$ \\
\hline 7.4 & $\begin{array}{l}\text { Incentivos eficazes para fornecedores, a empresa e clientes existem de forma a recompensar } \\
\text { melhorias de desempenho compartilhadas ou redução de custos? }\end{array}$ \\
\hline
\end{tabular}

Fonte: Norma SAE J4000.

e) Elemento 8 (Produto e Gestão do Produto) - leva em consideração o uso de ferramentas ligadas à gestão do ciclo de vida de produto e à utilização de equipes multidisciplinares com competências específicas para o desenvolvimento de novos produtos, com o intuito de reduzir, principalmente, o tempo de lançamento desses novos produtos ao mercado e o custo associado a esta tarefa;

Quadro 5 - Questões do Elemento 8

\begin{tabular}{|c|l|}
\hline Elemento & \multicolumn{1}{|c|}{ Questão } \\
\hline 8.1 & $\begin{array}{l}\text { Projetos de produtos e processos são conduzidos por equipes totalmente integradas com } \\
\text { representantes de todas as partes interessadas? }\end{array}$ \\
\hline 8.2 & $\begin{array}{l}\text { Custos, desempenho e especificação de requisitos para produtos e processos são inequívocos, } \\
\text { mensuráveis e de concordância de todas as partes interessadas? }\end{array}$ \\
\hline
\end{tabular}




\begin{tabular}{|c|l|}
\hline 8.3 & $\begin{array}{l}\text { Projetos de produtos e processos são conduzidos a partir de um enfoque sistêmico do ciclo de } \\
\text { vida, com total aderência aos princípios de DFM/DFA (Projeto para fabricar e montar) e } \\
\text { concordante com os princípios Lean? }\end{array}$ \\
\hline 8.4 & $\begin{array}{l}\text { Parâmetros de capacidade de processos e projetos de produtos são de grande robustez, } \\
\text { consistentes com as boas práticas de negócios? }\end{array}$ \\
\hline 8.5 & $\begin{array}{l}\text { Provisões são feitas para o desenvolvimento do conhecimento da equipe objetivando } \\
\text { lançamentos de produtos e processos duráveis? }\end{array}$ \\
\hline 8.6 & $\begin{array}{l}\text { Tempo de processo (Lead time) de projetos de produtos e processos são mensuráveis são } \\
\text { reduzidos continuamente? }\end{array}$ \\
\hline
\end{tabular}

Fonte: Norma SAE J4000.

f) Elemento 9 (Produto e Fluxo de Processos) - nesta última categoria encontra-se a maior parte das ferramentas que atualmente se aplicam à área da engenharia e que buscam orientar o fluxo de produção a seguir uma sincronia com as necessidades dos clientes.

Quadro 6 - Questões do Elemento 9

\begin{tabular}{|c|c|}
\hline Elemento & Questão \\
\hline 9.1 & O ambiente de trabalho é limpo, organizado e regularmente auditado contra as práticas de 5S? \\
\hline 9.2 & $\begin{array}{l}\text { A empresa possui um sistema eficaz de manutenção preventiva, com as devidas manutenções } \\
\text { conforme frequência prescrita para todos os equipamentos? }\end{array}$ \\
\hline 9.3 & $\begin{array}{l}\text { Lista de materiais está precisamente catalogada e trabalhos padronizados estão precisamente } \\
\text { descritos, com o detalhamento de tempo por tarefa e com o valor agregado conhecido? }\end{array}$ \\
\hline 9.4 & $\begin{array}{l}\text { Fluxo de valor está totalmente mapeado e os produtos estão fisicamente separados em fluxos } \\
\text { individualizados? }\end{array}$ \\
\hline 9.5 & $\begin{array}{l}\text { A sequência de produção está nivelada conforme a puxada do cliente e a demanda está nivelada } \\
\text { em todo o período planejado para a produção? }\end{array}$ \\
\hline 9.6 & Fluxo de processo é controlado por ferramentas visuais, internas ao processo? \\
\hline 9.7 & $\begin{array}{l}\text { O processo está sob controle estatístico contra os requisitos de capacidade, com a variabilidade } \\
\text { do processo em contínua redução? }\end{array}$ \\
\hline 9.8 & $\begin{array}{l}\text { Ações preventivas, usando ferramentas de solução estruturada de problema são usadas e } \\
\text { documentadas para cada não conformidade de produto e/ou processo? }\end{array}$ \\
\hline 9.9 & $\begin{array}{l}\text { Fluxo de produção começa somente após uma ordem de expedição? Fluxo opera na taxa média } \\
\text { de demanda (Takt Time), em quantidades unitárias, para o ponto de necessidade do cliente? }\end{array}$ \\
\hline 9.10 & $\begin{array}{l}\text { Procedimentos são existentes e seguidos, resultando em redução constante do tempo de troca } \\
\text { entre produtos (setup) e redução do tamanho de lotes? }\end{array}$ \\
\hline 9.11 & $\begin{array}{l}\text { Layout da fábrica facilita o sincronismo de fluxo contínuo de material e produtos no interior da } \\
\text { fábrica movimentam-se cada vez menos, resultado de melhorias das rotas internas? }\end{array}$ \\
\hline 9.12 & $\begin{array}{l}\text { Métodos de trabalhos padronizados são documentados, de uso efetivo, distribuem a carga de } \\
\text { trabalho igualmente de forma a eliminar desperdícios e em conformidade com a taxa média de } \\
\text { demanda? }\end{array}$ \\
\hline 9.13 & $\begin{array}{l}\text { O fluxo de valor é continuamente examinado e melhorado conforme revisões pré-agendadas e } \\
\text { regulares? }\end{array}$ \\
\hline
\end{tabular}

Fonte: Norma SAE J4000.

Para avaliar o grau de implementação de cada um desses elementos são definidos os componentes que abordam aspectos específicos e relevantes na implantação dos princípios da operação enxuta. Embora cada um dos elementos tenha igual peso na implementação, a importância relativa de cada um para o sucesso da implementação do Sistema Lean 
Production é refletida pelo número de componentes relacionados a cada elemento (SAE 1999a, 1999b).

A Norma J4000 define um número total de 52 componentes, assim como um percentual atribuído ao grau de importância dado a cada elemento, conforme apresentado na Tabela 1.

Tabela 1 - Representação dos elementos contidos na Norma SAE J4000 e seus relativos pesos

\begin{tabular}{|l|l|c|c|}
\hline Elemento & \multicolumn{1}{|c|}{ Tema Principal } & $\begin{array}{c}\text { Número de } \\
\text { Componentes }\end{array}$ & Peso \\
\hline Elemento 4 & Gerência e confiabilidade & 12 & $25 \%$ \\
\hline Elemento 5 & Pessoas e RH & 13 & $25 \%$ \\
\hline Elemento 6 & Sistema de Informação & 4 & \multirow{2}{*}{$25 \%$} \\
\hline Elemento 7 & Relação Cliente/Fornecedor e Organização & 4 & \multirow{2}{*}{$25 \%$} \\
\hline Elemento 8 & Produto e Gestão de Produto & 6 & 13 \\
\hline Elemento 9 & Produto e Fluxo de Processos & & \\
\hline
\end{tabular}

Fonte: Norma SAE J4000.

A cada um dos componentes é associada uma escala de avaliação do nível de implementação, a qual orienta a comparação do nível de aplicação do componente em função das melhores práticas aplicadas na indústria, conforme apresentado na Tabela 2.

Tabela 2 - Escala do nível de atendimento em relação à implementação das práticas

\begin{tabular}{|c|c|l|}
\hline Nível & Pontuação & \multicolumn{1}{c|}{ Significado } \\
\hline $\begin{array}{c}\text { Nível 0 } \\
\text { (L0) }\end{array}$ & 0 & $\begin{array}{l}\text { O componente não está implementado ou existem inconsistências fundamentais } \\
\text { na sua implementação. }\end{array}$ \\
\hline $\begin{array}{c}\text { Nível 1 } \\
\text { (L1) }\end{array}$ & 1 & $\begin{array}{l}\text { O componente está implementado mais ainda existem inconsistências menos } \\
\text { significativas na sua implementação. }\end{array}$ \\
\hline $\begin{array}{c}\text { Nível 2 } \\
\text { (L2) }\end{array}$ & 2 & O componente está satisfatoriamente implementado. \\
\hline $\begin{array}{c}\text { Nível 3 } \\
\text { (L3) }\end{array}$ & 3 & $\begin{array}{l}\text { O componente está satisfatoriamente implementado e mostra um contínuo } \\
\text { melhoramento nos últimos 12 meses. }\end{array}$ \\
\hline
\end{tabular}

Fonte: Norma SAE J4000.

As considerações específicas para cada um desses níveis são definidas na norma J4001. No entanto, é importante mencionar que existem exceções: os componentes 4.9, 4.11, 4.12, 4.13, 5.6, 5.10, 5.11, 5.12 e 6.2 admitem somente dois níveis de implementação: L0 (o componente não está presente) e L2 (o componente está presente). Já os componentes 5.9 e 6.4 consideram somente três níveis de implementação: L0, L2 e L3.

Outra consideração importante é o fato de que, embora a norma SAE J4000 tenha sido criada e aplicada, em grande parte, dentro do setor automotivo, o questionário aplicado referese à verificação do uso de uma metodologia de uso comum, a qual tem sido usada com excelentes resultados fora desse ambiente. 
No entanto, as normas SAE J4000 e J4001 não definem uma forma agregada de se medir o grau de implementação das práticas da gestão enxuta para um elemento específico ou para uma empresa como um todo, sendo que Lucato, Maestrelli e Vieira Jr. (2006), em um estudo teórico, propuseram a mensuração do que se denominou de Grau de Aderência à Norma para cada elemento, o qual está definido através da Fórmula 1 abaixo. Da mesma maneira, o Grau de Enxugamento para uma empresa pode ser definido através da Fórmula 2, conforme detalhado a seguir.

- O Grau de Implementação de um elemento genérico "e" da norma SAE J4000 (grau de enxugamento desse elemento) pode ser obtido dividindo-se a somatória dos pontos conseguidos na avaliação dos componentes desse elemento pelo número máximo de pontos possíveis para essa mesma avaliação, ou seja:

$$
\begin{gathered}
g_{e}=\frac{\left(\sum \text { dos pontos obtidos na avaliação dos componentes do elemento " } e "\right)}{\left(\sum \text { dos pontos máximos possíveis para os componentes do elemento " } e "\right)} \\
(\text { Fórmula } 1)
\end{gathered}
$$

- O Grau de Enxugamento (g) é dado pela divisão do somatório dos graus de enxugamentos dos elementos (ge) pelo número de elementos considerados na comparação (p).

$$
\left.g=\frac{\left(\sum g_{e}\right)}{p} \quad \text { (Fórmula } 2\right)
$$

